FABIANA MONTEIRO PARRO

\title{
O ERRO NA AÇÃO RESCISÓRIA
}

\author{
DisSertaÇão de MeSTRado \\ Orientador: Prof. Dr. Antonio Carlos Marcato
}

FACULDADE DE DIREITO DA USP

SÃO PAULO

2011 


\section{FABIANA MONTEIRO PARRO}

\section{O ERRO NA AÇÃO RESCISÓRIA}

Dissertação de Mestrado apresentada à Banca Examinadora da Faculdade de Direito da Universidade de São Paulo, como exigência parcial para a obtenção do título de Mestre em Direito, sob orientação do Prof. Dr. Antonio Carlos Marcato.

FACULDADE DE DIREITO DA USP

SÃO PAULO

2011 
Aos queridos Sofia e Miguel que, mesmo sem saber, me deram forças para sempre seguir adiante. 


\section{RESUMO}

O presente trabalho tratou do erro na ação rescisória, compreendendo tanto o erro de fato como o erro de direito, apontando eventuais equívocos e acertos da doutrina e jurisprudência sobre o tema.

Na primeira parte do estudo estabeleceu-se as premissas necessárias para as demais, iniciando-se por uma breve introdução a respeito da prestação jurisdicional e seus escopos, pois a ação rescisória não só é meio de prestação jurisdicional, como também é meio de revisão dessa mesma tutela prestada pelo Estado, passando-se, posteriormente, a uma sucinta apresentação da garantia da coisa julgada.

Em seguida, ingressando já no tema da ação rescisória, na parte segunda traçou-se um panorama geral acerca do instituto, estabelecendo as principais diferenças entre a ação rescisória e os demais meios de impugnação das decisões judiciais, nos quais se insere a ação rescisória, dando ênfase à excepcionalidade do instituto ora em estudo, justamente por ser meio de revisão da coisa julgada, que goza de proteção constitucional.

$\mathrm{Na}$ terceira parte, analisou-se o objeto da ação rescisória, que são as sentenças de mérito transitadas em julgado, apontando as possíveis decisões que podem abrir oportunidade ao manejo da ação rescisória, inclusive tratando de questão atual, que concerne à nova definição de sentença de mérito, concluindo-se pela impossibilidade de cisão formal da sentença, bem como examinou-se as principais divergências existentes no que tange às demais decisões, terminando, ainda, com uma breve abordagem do tratamento conferido à ação rescisória no anteprojeto do Código de Processo Civil.

Finalmente, na quarta parte, foram feitas considerações sobre as principais questões que surgem em relação ao erro na ação rescisória à luz da doutrina nacional e italiana, bem como acerca dos erros e acertos da jurisprudência dos tribunais superiores a respeito do tema. Demonstrou-se que, para a ação rescisória por erro de fato exige-se apenas a existência de um requisito, qual seja, a ausência de controvérsia sobre ponto a respeito de que a sentença teve que se pronunciar ou teria que se pronunciar.

Quanto ao erro de direito, concluiu-se que, para fins da ação rescisória, não é necessário nem que a norma seja clara, nem que a violação se dê contra a literalidade da norma, pois, dificilmente um órgão julgador irá contrariar uma norma de forma clara e frontal.

Palavras-chave: sentença judicial - coisa julgada - ação rescisória - erro 


\section{ABSTRACT}

This paper addresses the error in actions for reversal of judgment, including both errors in fact and errors at law, and points out some possibly mistaken and correct understandings of legal scholars and case law on the subject.

The first part of this study lays down the premises required for its other parts, beginning with a short introduction regarding jurisdictional relief and its scopes, since an action for reversal of judgment is not only a means of seeking jurisdictional relief, but also a means of revising such relief as provided by the State. Then, a brief presentation is given on the assurance of res judicata.

Next, now entering the realm of actions for reversal of judgment, its second part provides an overview of their institution, setting forth the main differences between actions for reversal of judgment and other means of challenging court rulings, wherein actions for reversal of judgment are included, emphasizing the exceptional nature of the institution studied herein, precisely because such actions are a means of revising a res judicata, which enjoys constitutional protection.

Its third part analyzes the subject-matter of actions for reversal of judgment, aimed at judgments on merit that have become res judicata, pointing out rulings that possibly can afford an opportunity for pursuing an action for reversal of judgment, including in dealing with a current issue, which concerns a new definition of judgment on merit, and then it concludes for the impossibility of formally splitting a judgment. It also examines the main existing divergences as regards other rulings, and it closes, furthermore, with a brief discussion of the treatment given to actions for reversal of judgment in the preliminary bill of law for the Code of Civil Procedure.

Finally, in its fourth part, some comments are made on the main issues that arise in connection with errors in actions for reversal of judgment, in light of Brazilian and Italian legal scholarship, and on some mistaken and correct understandings in the case law of higher courts regarding the subject. It is demonstrated that for an action for reversal of judgment upon an error of fact, only one existing requirement is called for, namely, the absence of any dispute over a point that had to be heard, or would have to be heard, in the judgment.

As for errors at law, the conclusion is reached that for the purposes of an action for reversal of judgment, it is neither necessary for the rule to be clear nor for the violation to be against the literalness of the rule, because a judging authority will hardly contradict a rule in a clear and outright manner.

Keywords: legal judgment - res judicata - action for reversal of judgment - error 


\section{SUMÁRIO}

\section{A - PARTE PRIMEIRA}

I. INTRODUÇÃO.

II. A PRESTAÇÃO JURISDICIONAL E SEUS ESCOPOS ……………………………........11

III. A GARANTIA CONSTITUCIONAL DA COISA JULGADA …...................................... 16

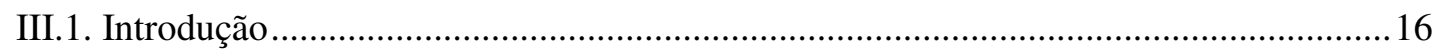

III.2. Aspectos positivo e negativo da coisa julgada ....................................................... 18

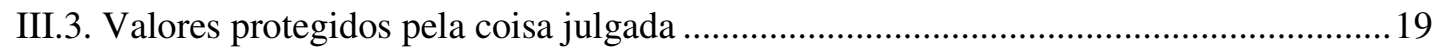

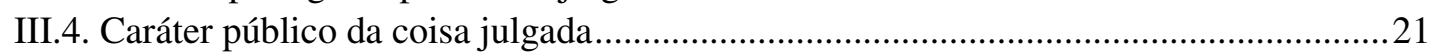

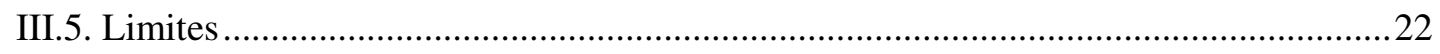

\section{B - PARTE SEGUNDA}

I. GENERALIDADES SOBRE OS MEIOS DE IMPUGNAÇÃO DAS DECISÕES JUDICIAIS: MANDADO DE SEGURANÇA; RECURSOS; AÇÃO ANULATÓRIA.

II. AÇÃO RESCISÓRIA COMO MEIO EXCEPCIONAL DE IMPUGNAÇÃ̃ .................32

II.1. Função e escopos da ação rescisória ........................................................................... 35

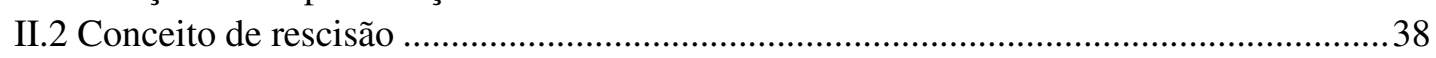

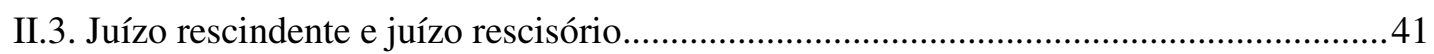

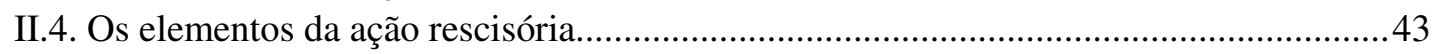

\section{C - PARTE TERCEIRA}

I. DECISÕES SUJEITAS À AÇÃO RESCISÓRIA …...........................................................52

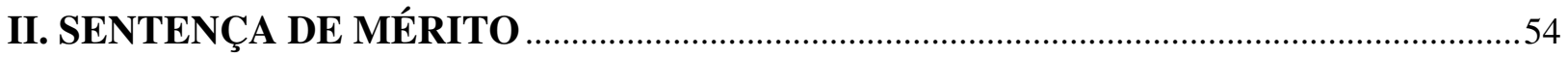

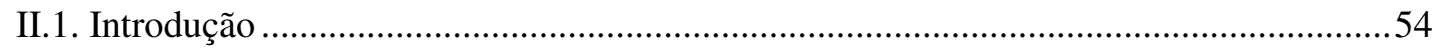

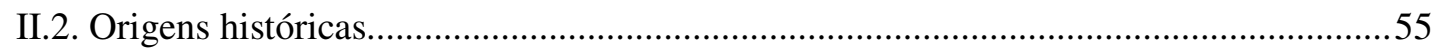

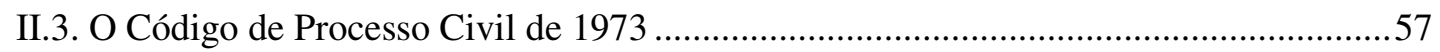

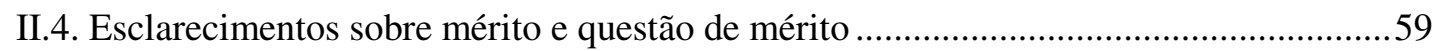

II.5. Alterações introduzidas pela Lei n. 11.232/05 .............................................................60

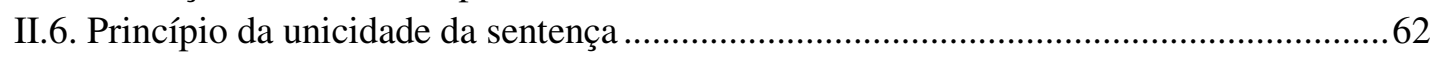

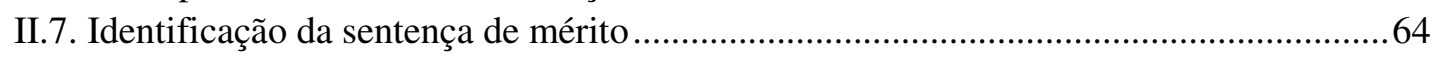

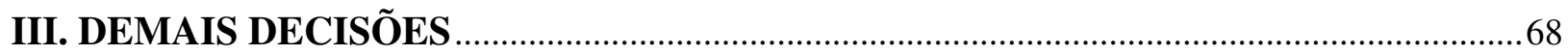

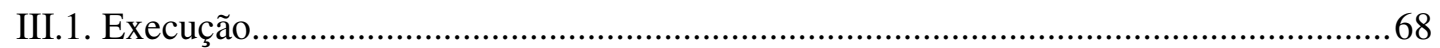

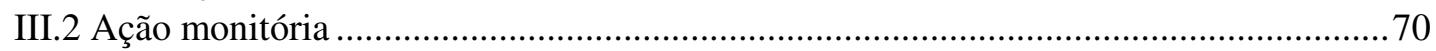

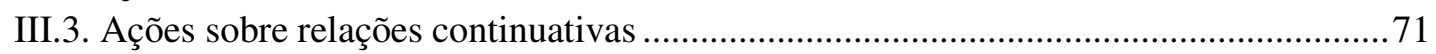

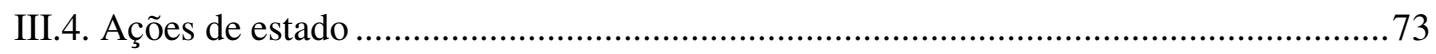

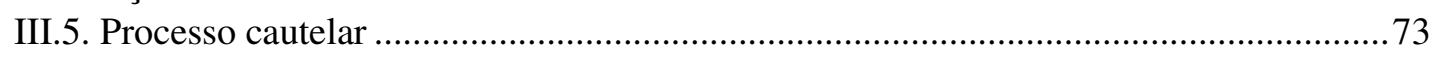

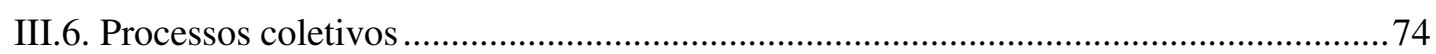

III.7. Decisões monocráticas proferidas com base no art. 557 do CPC....................................75 
III.8. Decisões interlocutórias. .76

III.9. Decisões que decretam a carência de ação ..........................................................78

III.10. Decisões do Juizado Especial Cível, decisões nas ações diretas de constitucionalidade e inconstitucionalidade e nas arguições de descumprimento de preceito fundamental ....................................................8 80

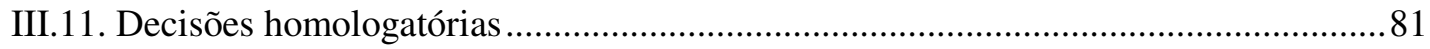

III.12. Jurisdição voluntária...............................................................................8 81

IV. BREVES CONSIDERAÇÕES SOBRE A AÇÃO RESCISÓRIA NO ANTEPROJETO DO CÓDIGO DE PROCESSO CIVIL

\section{D - PARTE QUARTA}

I. O ERRO COMO FUNDAMENTO DA AÇÃO RESCISÓRIA

I.1. Introdução

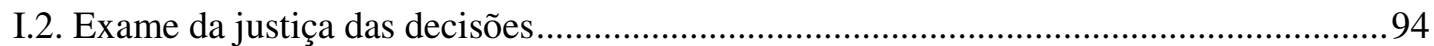

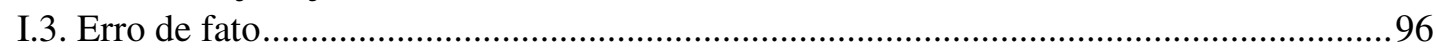

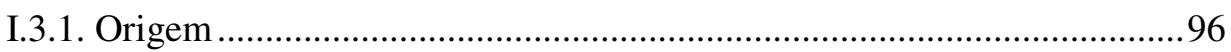

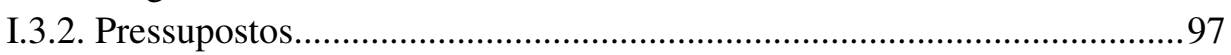

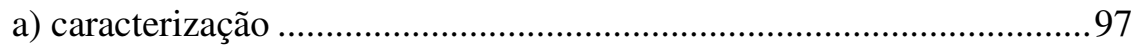

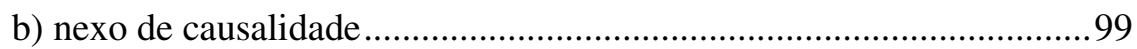

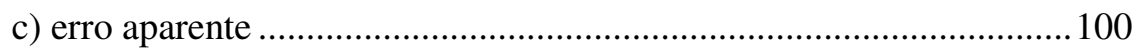

d) fatos que podem ensejar a ação rescisória .........................................101

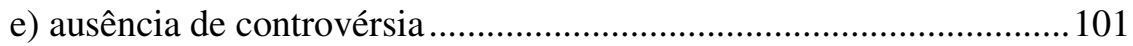

f) ausência de pronunciamento judicial ..................................................103

I.3.3. Casos de erro de fato na jurisprudência italiana ......................................106

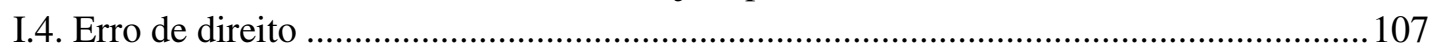

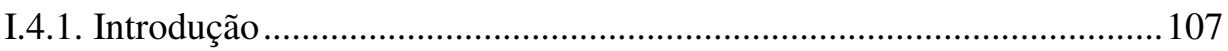

I.4.2. Violação à literal disposição de lei ...................................................... 108

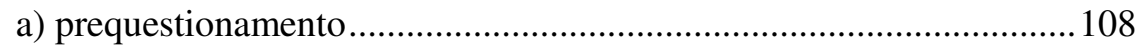

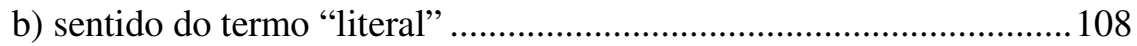

c) extensão do termo "lei" ................................................................110

d) error in procedendo e error in iudicando ...........................................112

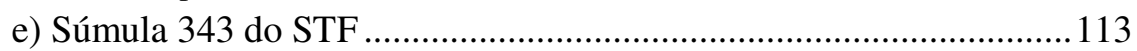

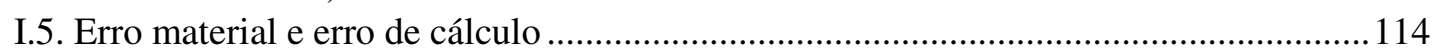

II. DIFERENCIAÇÃO ENTRE ERRO DE FATO, ERRO DE DIREITO E DEMAIS CAUSAS DE PEDIR

III. A POSIÇÃO DOS TRIBUNAIS SUPERIORES A RESPEITO DA RESCISÓRIA FUNDADA EM ERRO 


\section{A - PARTE PRIMEIRA}




\section{INTRODUÇÃO}

O presente trabalho trata do erro na ação rescisória, compreendendo tanto o erro de fato como o erro de direito, inclusive do error in iudicando e do error in procedendo, apontando eventuais equívocos e acertos da doutrina e jurisprudência no trato do tema.

O erro de fato na ação rescisória está perfeitamente delineado no inciso IX do artigo 485 do Código de Processo Civil, tendo o legislado se inspirado para sua inclusão no nosso ordenamento, na legislação italiana ${ }^{1}$, razão pela qual é válido socorrer-se das lições doutrinárias e jurisprudenciais daquele país a respeito do tema. Quanto ao erro de direito para a ação rescisória, em razão da infinita gama de possibilidades que a questão pode suscitar, podendo-se admitir que, em praticamente todos os incisos do artigo 485 do Código de Processo Civil poderá haver, também, erro de direito, o presente trabalho irá se restringir ao meio mais típico de erro de direito para a ação rescisória, que é a violação à literal disposição de lei, constante do inciso V, do mencionado artigo.

O presente estudo está dividido em três partes: na primeira se estabelecerá as premissas necessárias para os demais, iniciando-se por uma breve introdução a respeito da prestação jurisdicional e seus escopos, pois a ação rescisória não só é meio de prestação jurisdicional, como também é meio de revisão dessa mesma tutela prestada pelo Estado. Posteriormente, passar-se-á a uma sucinta apresentação da garantia da coisa julgada, que também se faz necessário, pois o instituto está intimamente ligado ao tema do presente trabalho, vez que a ação rescisória tem por escopo a cassação de decisões de mérito transitada em julgado e, assim, somente através da análise deste instituto que poder-se-á estabelecer os limites subjetivos e objetivos para a ação rescisória, havendo uma profunda ligação com a legitimidade e objeto da ação rescisória.

Em seguida, ingressando já no tema da ação rescisória, na parte segunda será traçado um panorama geral acerca do instituto, estabelecendo as principais diferenças entre a ação rescisória e os demais meios de impugnação das decisões judiciais, nos quais se insere a ação rescisória, dando ênfase à excepcionalidade do instituto ora em estudo, justamente por ser meio de revisão da coisa julgada, que goza de proteção constitucional.

\footnotetext{
${ }^{1}$ Ver a respeito, BARBOSA MOREIRA, José Carlos. Comentários ao Código de Processo Civil. Rio de Janeiro: Forense, 2008. v. 5, p. 146 e ss.
} 
$\mathrm{Na}$ terceira parte, analisar-se-á o objeto da ação rescisória, que são as sentenças de mérito transitadas em julgado, apontando as possíveis decisões que podem abrir oportunidade ao manejo da ação rescisória, inclusive tratando de questão atual, que concerne à nova definição de sentença de mérito e as divergências existentes no que tange às demais decisões, terminando, ainda, com um breve exame do tratamento conferido à ação rescisória no anteprojeto do Código de Processo Civil.

Finalmente, na quarta parte, serão avaliadas as principais questões que surgem em relação ao erro na ação rescisória, iniciando-se com o estudo do erro de fato, a possibilidade da verificação da justiça das decisões por meio da ação rescisória, sendo um contra-senso a afirmação de sua impossibilidade, tendo em vista que o referido instituto vincula-se justamente à proteção do valor justiça, em detrimento do valor segurança. Após, verificar-se-á quais os pressupostos para incidência do erro de fato como causa da ação rescisória, apontando os equívocos cometidos pela doutrina nacional, bem como traçando um paralelo com a doutrina italiana, fonte de inspiração do instituto em análise.

Posteriormente, será feito o estudo acerca das principais questões que envolvem o erro de direito, e as imprecisões e incorreções doutrinárias sobre o erro de direito, passando-se, então, aos esclarecimentos quanto à diferenciação com o erro material, não sujeito à ação rescisória e às demais causas de pedir, em especial com aquelas mais próximas do erro de fato e de direito que poderiam gerar alguma confusão, e ainda entre os dois erros como causa para a ação rescisória. Após, serão feitas considerações sobre o posicionamento do Supremo Tribunal Federal e do Superior Tribunal de Justiça quanto ao erro de fato e de direito para a ação rescisória, explicitando as divergências entre os entendimentos, com a doutrina e os equívocos cometidos e suas consequências práticas. Por fỉm, serão apresentadas as conclusões teóricas e práticas extraídas do presente estudo.

Impende ressaltar, ainda, que sempre que se mencionar a coisa julgada no presente trabalho, sem qualquer indicação, estar-se-á referindo-se à coisa julgada material. 


\section{A PRESTAÇÃO JURISDICIONAL E SEUS ESCOPOS}

Desde que o Estado chamou para si o monopólio da prestação jurisdicional, comprometeu-se a oferecer uma solução dos conflitos, de modo pacífico, eficaz e imparcial, impedindo a autotutela e a prevalência do mais forte sobre o mais fraco. Através da jurisdição, o Estado exerce o poder de decidir imperativamente os conflitos, impondo sua decisão sobre as partes. Tudo isso, a fim de satisfazer as necessidades sociais ao dirimir as controvérsias que surgissem, de modo a assegurar a paz social. E esse meio estatal de solução das controvérsias sociais é justamente o processo judicial, o qual deve atender a vários princípios, refletindo os valores vigentes que estão impregnados na sociedade em que está inserido.

Assim, para que a solução estatal seja legítima, deve observar certos requisitos, sintetizados na expressão "devido processo legal" ${ }^{2}$, para que seja apta a fornecer os resultados desejados. É corrente na doutrina que vários são os escopos da atividade jurisdicional $^{3}$, sendo que, no momento, o que mais importa para o presente trabalho, é o escopo social do processo, que se traduz em "eliminar conflitos mediante critérios justos" A eliminação de conflitos está associada à idéia de segurança ou certeza, pois a simples existência do conflito, ou mesmo a pendência judicial que vise eliminá-lo, é fonte de insegurança e insatisfação às partes envolvidas no litígio e à sociedade, de um modo geral.

O princípio da segurança jurídica, segundo autorizada doutrina, diz-se inerente ao próprio Estado democrático de direito, podendo ser formulado do seguinte modo: "o indivíduo têm do direito poder confiar em que aos seus actos ou às decisões públicas incidentes sobre os seus direitos, posições ou relações jurídicas alicerçados em normas jurídicas vigentes e válidas por esses actos jurídicos deixado pelas autoridades

\footnotetext{
${ }^{2}$ "Entende-se, com essa fórmula, o conjunto de garantias constitucionais que, de um lado, asseguram às partes o exercício de suas faculdades e poderes processuais e, do outro, são indispensáveis ao correto exercício da função jurisdicional." CINTRA, Antonio Carlos de Araujo; GRINOVER, Ada Pellegrini; DINAMARCO, Cândido Rangel. Teoria geral do processo. São Paulo: Ed. Revista dos Tribunais, 1990. p. 78. Segundo Canotilho, a cláusula do "devido processo legal", deve ser vista sob uma visão ampliativa, "compreendido como um processo político valorativamente orientado para a defesa de valoes e direitos fundamentais." In CANOTILHO, J. J. Gomes. Direito constitucional e teoria da constituição. 4. ed. Coimbra: Almedina, p. 481.

${ }^{3}$ Ver a respeito, DINAMARCO, Cândido Rangel. A instrumentalidade do processo. São Paulo: Malheiros Ed., 2008. p. 177 e ss.

${ }^{4}$ A instrumentalidade do processo, cit., p. 191.
} 
com base nessas normas se ligam os efeitos jurídicos previstos e prescritos no ordenamento jurídico."5

Deve-se acrescentar, ainda, que o escopo social do processo deve se pautar, igualmente, pelo critério da justiça das decisões, que revela uma preocupação com o conteúdo, vale dizer, com a qualidade da solução oferecida, sob pena de cairmos num vazio se essas mesmas soluções não se fundassem no valor da justiça, o que poderia acabar por ser palco para insatisfações ainda maiores, e o meio estatal de solução de controvérsias cairia no descrédito da sociedade, ao invés de implementar a desejada paz social 6 .

As decisões judiciais devem se pautar por critérios de justiça vigentes na sociedade no momento em que proferidas, devendo o juiz ser permeável ao contexto axiológico então vigente, a fim de não se afastar dos critérios de justiça que regem a sociedade na qual a decisão deve se inserir, pois "o momento de decisão de cada caso concreto é sempre um momento valorativo"7 e, as decisões judiciais, a fim de cumprirem seu escopo máximo, devem estar revestidas do critério de justiça, somente alcançado através do comprometimento do judiciário com os valores de justiça vigentes na sociedade. Tal não significa ser possível ao órgão judicial decidir com base na equidade, ou ignorar alguma norma vigente, mas dar às normas aplicáveis ao caso, a melhor interpretação, de acordo com os valores então vigentes, de forma a assegurar decisões mais justas.

Esses dois valores (segurança e justiça), devem ser igualmente contrabalançados e devem estar presentes na solução oferecida, a fim de que os escopos desejados sejam atingidos e, da mesma forma, de modo a legitimar a solução encontrada. Note-se que esses dois valores não são, necessariamente, conflitantes $^{8}$. Porém, no caso de tensão ou conflitos entre valores ou princípios, vale lembrar que, diferentemente de como ocorre com o conflito entre normas, os valores não se excluem, havendo somente a preponderância de um sobre o outro, em determinada situação. Neste sentido é a valiosa lição do mestre Canotilho: "Daí o reconhecimento de momento de tensão ou antagonismo entre os vários princípios e a necessidade, atrás exposta, de aceitar que os princípios não

\footnotetext{
5 CANOTILHO, J. J. Gomes. Direito constitucional e teoria da constituição, cit., p. 256.

"A eliminação de litígios sem o critério de justiça equivaleria a uma sucessão de brutalidades arbitrárias que, em vez de apagar os estados anímicos de insatisfação, acabaria por acumular decepções definitivas no seio da sociedade.” DINAMARCO, Cândido Rangel. A instrumentalidade do processo, cit., p. 347.

7 DINAMARCO, Cândido Rangel. A instrumentalidade do processo, cit., p. 347.

${ }^{8}$ A respeito, ver DINAMARCO, Cândido Rangel. A instrumentalidade do processo, cit., especialmente n. 32 , p. 271 e ss.
} 
obedecem, em caso de conflito, a uma 'lógica do tudo ou nada', antes podem ser objeto de ponderação e concordância prática, consoante o seu 'peso' e as circunstâncias do caso." 9 .

Dessa forma, o processo será sempre um meio predisposto à consecução dos objetivos estabelecidos, e tais objetivos são fixados pela sociedade em que está inserido, através dos valores então vigentes, aos quais o processo é permeável.

Conforme comumente difundido na doutrina, a resposta fornecida pelo Estado através da prestação jurisdicional é a tutela jurisdicional 1011 , a qual, segundo concepção moderna, não é prestada para proteção de direitos (como anteriormente preconizado), mas em favor de pessoas 1213 , ou seja, é dada àquele que tiver razão perante o direito material, pois o escopo social do processo não visa a resguardar direitos, mas pessoas, pacificando-as.

Nessa medida, e considerando-se o enfoque do processo civil de resultados, segundo o qual o que importa são os resultados úteis que o processo pode propiciar a quem se socorrer dele, assumem relevo os efeitos produzidos com a tutela jurisdicional concedida através da prestação jurisdicional, exercida pelo Estado-juiz, por meio do processo judicial.

Esses efeitos, como é notório, ostentam diversas formas, de acordo com a natureza do direito material controvertido, e é justamente a partir da estabilização desses efeitos, que adquirem imutabilidade com ocorrência da coisa julgada material, que o sistema procura atingir o escopo social da pacificação, conferindo maior segurança nas relações, impedindo que a mesma situação seja novamente analisada por qualquer órgão

\footnotetext{
9 CANOTILHO, J. J. Gomes. Direito constitucional e teoria da constituição, cit., p. 1146.

${ }^{10}$ Neste sentido, Dinamarco, Fundamentos do processo civil moderno. São Paulo: Malheiros Ed., 2002. v. 2: "A tutela jurisdicional, assim enquadrada no sistema de proteção aos valores do homem, não se confunde com o próprio serviço realizado pelos juízes no exercício da função jurisdicional. Não se confunde com a jurisdição. A tutela é o resultado do processo em que essa função se exerce. Ela não reside na sentença em si mesma como ato processual, mas nos efeitos que ela projeta para fora do processo e sobre as relações entre pessoas." (p. 811 e ss.).

${ }^{11}$ Em sentido diverso, conferindo maior amplitude ao conceito de tutela jurisdicional, YARSHELL, Flávio Luiz. Tutela jurisdicional. São Paulo: Atlas, 1998: "Conforme demonstrado, a locução tutela jurisdicional pode ser abrangente não apenas do provimento final ou do resultado do processo - seja ele encarado sob o ângulo do vencedor, seja encarado sob o ângulo do vencido - , mas também dos meios predispostos ao atingimento daquele provimento ou resultado." (p. 37).

${ }_{12}^{12}$ DINAMARCO, Cândido Rangel. Fundamentos do processo civil moderno, cit.

${ }^{13}$ Em sentido contrário, Bedaque, in Direito e processo: influência do direito material sobre o processo. São Paulo: Malheiros Ed., 2003, segundo o qual: "Assim, tutela jurisdicional tem o significado de proteção de um direito ou de uma situação jurídica, pela via jurisdicional.” (p. 29).
} 
judicial, após ter sido definitivamente julgada. Ora, de nada adiantaria um sistema de proteção às pessoas que permitisse, infinitamente, a revisão de suas decisões, tornando os litígios infindáveis, o que acabaria por gerar mais insegurança e instabilidade nas relações jurídicas, não sendo atingido o escopo pacificador da jurisdição, consistindo, ao revés, de estímulo à litigiosidade. Assim, a imunização das decisões é inerente ao próprio sistema e à consecução de seus propósitos.

O escopo da pacificação só é atingido pela entrega da tutela jurisdicional, ou seja, quando a tutela jurisdicional soluciona a questão de direito material posta em juízo, conferindo proteção à pessoa que fizer jus à entrega da tutela pleiteada.

Nesse aspecto, cumpre esclarecer que, ao réu, é possível a concessão da tutela jurisdicional, o que ocorre na hipótese de a demanda ser julgada improcedente, pois, dessa forma, o réu não terá sua esfera de direitos atingida por aquela pretensão do autor, de modo definitivo, não tendo que se submeter novamente à pretensão veiculada através daquela demanda, quer dizer, aquele autor não poderá mais pleitear aquela tutela que já foi rejeitada pelo órgão judicial estatal de forma definitiva ${ }^{14}$.

Destarte, assume relevo, dentro do sistema processual vigente, mormente através das atuais concepções do processo civil de resultados e da efetividade da tutela jurisdicional, o resultado prático obtido com o processo judicial, ou seja, os efeitos que a tutela jurisdicional provocará na vida dos litigantes. E, para que o escopo social da pacificação seja atingido, esse resultado deve, a partir de um certo momento, restar intangível, de modo a garantir a segurança nas relações jurídicas e, assim, a almejada paz social.

Portanto, para o adequado funcionamento do sistema, e para que ele atinja seus propósitos (dentre eles, a paz social), é necessário que existam mecanismos adequados que propiciem a segurança das decisões, pois tal é inerente ao bom funcionamento deste. Luiz Guilherme Marinoni fala, inclusive, de um "direito à obtenção de uma tutela

\footnotetext{
${ }^{14}$ Neste sentido, Dinamarco, Fundamentos do processo civil moderno, cit.: "Assentado que a tutela jurisdicional plena será outorgada sempre àquele dos litigantes que tiver razão segundo os ditames do direito substancial, segue-se que a tutela ministrada ao réu em caso de improcedência da demanda do autor consiste em aliviá-lo da pretensão deste. A sentença de improcedência da demanda do autor tem sempre o mesmo teor de uma sentença que julgasse procedente ação meramente declaratória movida por ele, réu." (p. 828).
} 
jurisdicional indiscutível e imutável" em decorrência do direito fundamental à tutela jurisdicional 15 .

Em suma, no que se refere diretamente ao tema do presente trabalho, impende ressaltar que o escopo social magno da prestação jurisdicional é o da pacificação social e, para que este fim seja atingido, deve-se dotar o processo de ferramentas aptas (devido processo legal) a propiciar uma decisão justa e segura, assumindo relevo o resultado prático que a tutela jurisdicional entregue exercerá efetivamente na vida das pessoas em litígio. E, ainda, uma das ferramentas para que se alcance a segurança jurídica, é dotar esse resultado de certa estabilidade, de modo a não ser mais possível, a partir de um determinado ponto, a revisão da prestação jurisdicional entregue.

${ }^{15}$ MARINONI, Luiz Guilherme. Coisa julgada inconstitucional. São Paulo: Ed. Revista dos Tribunais, 2008. p. 62 . 


\section{A GARANTIA CONSTITUCIONAL DA COISA JULGADA}

\section{III.1 Introdução}

Nos tempos mais remotos, costumava-se afirmar que a coisa julgada faz do preto, branco e do quadrado, redondo, resumindo-se a proposição no brocado res judicata pro veritate habetur 16 . Assim, a concepção de coisa julgada era no sentido de ser uma verdade quase absoluta, capaz de alterar a realidade dos fatos, chegando-se até a se falar em "santidade da coisa julgada"17.

Todavia, o entendimento atual da coisa julgada não tem mais esse sentido tão absoluto, havendo corrente moderna que propõe, inclusive, sua revisão fora dos casos legalmente admissíveis, mesmo quando não presentes os requisitos legais, quando se vise proteger outros valores, igualmente ou até mais relevantes que os valores resguardados pela coisa julgada. Tal concepção é manifestada pelos defensores da doutrina da relativização da coisa julgada 18 .

De fato, os valores protegidos pela coisa julgada são os da segurança jurídica e da estabilidade das relações, atributos dos escopos sociais do processo, pois, através da imutabilidade da decisão, há o favorecimento da pacificação social. Mas, a coisa julgada também se relaciona com o escopo jurídico da prestação jurisdicional, contribuindo para a atuação da vontade concreta da lei 19.

Liebman foi o doutrinador que deu a maior contribuição para o estudo da coisa julgada, em sua obra "Eficácia e Autoridade da Sentença", considerada um divisor de águas sobre a matéria, por ter esclarecido diversos pontos que permaneciam duvidosos até

\footnotetext{
${ }^{16}$ AMERICANO, Jorge. Da acção rescisoria dos julgados no direito brasileiro. São Paulo: Casa Vanorden, 1922. p. 7 e ss.

${ }^{17}$ Expressão utilizada por alguns processualistas espanhóis, conforme leciona Moacyr Lobo da Costa, in COSTA, Moacyr Lobo da Cumulação de juízos na ação rescisória. São Paulo: [s.n.], 1986.

${ }^{18}$ Nesse sentido: DINAMARCO, Cândido Rangel. Relativizar a coisa julgada material. Revista Forense, Rio de Janeiro, v. 358, p. 11, nov./dez. 2001.

${ }^{19}$ Dinamarco, na obra A instrumentalidade do processo, cit., ressalta: "Também a autoridade da coisa julgada guarda relação com o escopo social magno do processo, uma vez que a definitiva pacificação não se obtém enquanto não conseguida a imunização das decisões judiciais. (...) Não se desconsidera que essa autoridade da res judicata, imunizando a decisão de mérito, mantém relação funcional com mais de um escopo do processo, ou seja, não somente como de pacificação mas ainda (pelo menos) com o jurídico de atuação da vontade concreta da lei." (A instrumentalidade do processo, cit., p. 197).
} 
então. A conceituação da coisa julgada, conforme definida por Liebman, encontrou acolhida na doutrina brasileira 20 , e a teoria por ele desenvolvida trouxe resultados para a legislação nacional.

Cabe afirmar, portanto que, segundo as valorosas lições de Liebman, a coisa julgada é definida como "a imutabilidade do comando emergente de uma sentença. Não se identifica ela simplesmente com a definitividade e intangibilidade do ato que pronuncia o comando; é, pelo contrário, uma qualidade, mais intensa e mais profunda, que reveste o ato também em seu conteúdo e torna assim imutáveis, além do ato em sua existência formal, os efeitos, quaisquer que sejam, do próprio ato." 21.

Nesse passo, conclui o renomado autor italiano que não se pode duvidar que a eficácia jurídica da sentença se distinga efetivamente da autoridade da coisa julgada, valendo-se da distinção formulada por Carnelutti entre imperatividade e imutabilidade da sentença, que são dois conceitos que não se identificam. Com efeito, a imperatividade se liga ao fato da obrigatoriedade da sentença, enquanto a imutabilidade se refere à impossibilidade de ser revista ou alterada a decisão que ficou coberta pela coisa julgada, sendo conceitos totalmente distintos.

Portanto, deve-se a Liebman a distinção entre os efeitos da sentença e a coisa julgada e a noção de que a coisa julgada não é um efeito daquela, mas uma qualidade que se agrega a tais efeitos.

$\mathrm{Na}$ prática, a coisa julgada material, segundo as palavras de Barbosa Moreira, "Quer isso dizer que a solução dada ao litígio pelo juiz se torna imune a contestações juridicamente relevantes, não apenas no âmbito daquele mesmo processo em que se proferiu a decisão, mas também fora dele, vinculando as partes e quaisquer juízes de eventuais processos subsequentes." 22.

\footnotetext{
${ }^{20}$ Em sentido parcialmente contrário, entende Barbosa Moreira, segundo o qual, a imutabilidade da coisa julgada não atingiria os efeitos da sentença, mas o seu conteúdo, como norma jurídica destinada a solucionar a situação jurídica concreta. Ver a respeito, "BARBOSA MOREIRA, José Carlos. Coisa julgada e declaração. In: . Temas de direito processual: (primeira série). São Paulo: Saraiva, 1988.

${ }^{21}$ LIEBMAN, Enrico Tullio. Eficácia e autoridade da sentença e outros escritos sobre a coisa julgada. Trad. Alfredo Buzaid e Benvindo Aires. Rio de Janeiro: Forense, 1945. p. 54.

${ }^{22}$ In BARBOSA MOREIRA, José Carlos. A eficácia preclusiva da coisa julgada material no sistema do processo civil brasileiro. In: 1988. p. 97. Temas de direito processual: (primeira série), São Paulo: Saraiva,
} 


\section{III.2 Aspectos positivo e negativo da coisa julgada}

Foi Savigny quem primeiro enxergou a dupla função da coisa julgada asseverando a existência de um "efeito consumptivo" (consumação) da contestação, fundada no princípio jurídico de que, depois de julgada, uma ação não pode ser intentada de novo 23 . Todavia, tal entendimento atribuía somente uma função negativa à coisa julgada, a de impedir uma nova ação, sem atribuir-lhe qualquer efeito positivo. O referido princípio levava em consideração somente a existência da sentença, e não seu conteúdo. Numa evolução desse pensamento, Savigny levou em consideração também o conteúdo da sentença, proclamando que a sentença posterior não deve contradizer o conteúdo da sentença anterior. Se, em uma lide posterior há uma questão já decidida em lide anterior, o novo juiz deve admitir por verdadeiro o conteúdo da primeira sentença e tê-lo por base na sua própria decisão. Passou, assim, a coisa julgada a ter uma função positiva, direcionada ao juiz que fosse analisar a segunda lide.

Liebman afirma, no entanto, que a autoridade da coisa julgada tem função meramente negativa, tendo em vista que, se os efeitos da sentença são totalmente independentes da coisa julgada e esta atua somente de forma a torná-los imutáveis, é evidente que a sua função é unicamente a de impedir qualquer outra sentença que contradiga ou contraste os efeitos produzidos pela sentença precedente. A chamada função positiva da coisa julgada em nada se relaciona com esta e constitui simplesmente a eficácia natural da sentença 24 .

Na Itália, a discussão a respeito da função negativa e positiva da coisa julgada tem razão de ser, uma vez que o ordenamento da península determinava que o juiz que recebesse novamente demanda anteriormente decidida, deveria julgar no mesmo sentido da decisão anterior, desempenhando, assim, a chamada função positiva da coisa julgada. Essa discussão não encontra lugar no direito brasileiro, face à ausência de disposição, em nosso ordenamento, semelhante à italiana 25 .

\footnotetext{
${ }^{23}$ NEVES, Celso. Coisa julgada civil. São Paulo: Ed. Revista dos Tribunais, 1971.

${ }^{24}$ LIEBMAN, Enrico Tullio. Eficácia e autoridade da sentença e outros escritos sobre a coisa julgada, cit., p. 58 e ss.

${ }^{25}$ Neste sentido são os comentários da professora Ada Pellegrini Grinover à obra de Liebman: "Ali, com efeito, como lembra Liebman (n. 18), só se admite recurso extraordinário para a proteção da coisa julgada quando 'a sentença for contrária a outra sentença precedente passada em julgado' (art. 494, n. 5, e 517, n. 8,
} 
No direito brasileiro prevalece o entendimento no sentido de que a coisa julgada cumpre função meramente negativa, na medida em que, exaurida a ação exercida, exclui-se a sua repropositura 26 , uma vez que o nosso ordenamento veda expressamente a decisão sobre demanda já decidida anteriormente (ne bis in idem) ${ }^{27}$, mesmo que a segunda decisão seja no mesmo sentido da anterior, diversamente do antigo ordenamento italiano, que permitia a reapresentação da demanda, apenas determinando que o juiz da segunda demanda julgasse no mesmo sentido em que decidida a anterior.

\section{III.3 Valores protegidos pela coisa julgada}

A coisa julgada é corolário do princípio da segurança jurídica, na medida em que visa resguardar a estabilidade das decisões judiciais, tornando-as imunes a ataques posteriores, a partir de um certo momento definido em lei. A esse respeito, Canotilho esclarece que: "As refracções mais importantes do princípio da segurança jurídica são as seguintes: (...) (2) relativamente a actos judiciais - inalterabilidade do caso julgado,"28. E adiante continua: “O princípio da segurança jurídica não é apenas um elemento essencial do princípio do estado de direito relativamente a actos normativos. As ideias nucleares da segurança jurídica desenvolvem-se em torno de dois conceitos: (1) estabilidade ou eficácia ex post da segurança jurídica dado que as decisões dos poderes públicos uma vez adoptadas, na forma e procedimento legalmente exigidos, não devem poder ser arbitrariamente modificadas, sendo apenas razoável a alteração das mesmas quando ocorram pressupostos materiais particularmente relevantes; (2) previsibilidade ou eficácia ex ante do princípio da segurança jurídica que, fundamentalmente, se reconduz à

cód. proc. civ. italiano) e não quando a sentença, embora tornando a julgar sobre o mesmo objeto, tenha julgado conforme. Mas no Brasil este último caso também dá margem à ação rescisória, nos termos do art. 485, IV, CPC (...)o vínculo não significa que o juiz esteja obrigado a rejulgar a matéria em igual sentido, mas sim que ele está impedido de rejulgá-la.

Assim sendo, não há por que falar-se, entre nós, em função positiva da coisa julgada ou da eficácia natural da sentença." In Notas ao $\S 3^{\circ}$, da obra Eficácia e autoridade da sentença e outros escritos sobre a coisa julgada, cit., p. 66 e ss.

${ }^{26}$ Em sentido contrário, Talamini, Coisa julgada e sua revisão. São Paulo: Ed. Revista dos Tribunais, 2005. p. 130 e ss., entendendo que no Brasil vigora tanto a função negativa como a positiva da coisa julgada, asseverando que a função positiva impõe às partes a obediência ao julgado e obrigando a autoridade judiciária a ajustar-se a ela, nos pronunciamentos que tenham como pressuposto a lide anterior, coberta pelo manto da coisa julgada. Todavia, nos termos colocados pelo autor, a função positiva da coisa julgada não teria as mesmas características daquela empregada pela doutrina italiana.

${ }^{27}$ Art. 471, caput, do CPC.

${ }^{28}$ CANOTILHO, J. J. Gomes. Direito constitucional e teoria da constituição, cit., p. 256. 
exigência de certeza e calculabilidade, por parte dos cidadãos, em relação aos efeitos jurídicos dos actos normativos."29.

Nos termos expostos, verifica-se que o valor da segurança jurídica é alçado a direito fundamental, inerente ao Estado democrático de direito ${ }^{30}$, do qual a coisa julgada é instrumento de realização, através da imunização das decisões judiciais, conferindo segurança às relações sociais. Assim, a coisa julgada foi concebida para conferir segurança jurídica, sendo meio necessário ao desenvolvimento econômico de outrora, sendo atributo exclusivo da atividade jurisdicional.

Destarte, a segurança conferida pela atividade jurisdicional, através da coisa julgada, não importa somente às partes da relação jurídica em que a coisa julgada se formou, mas também à sociedade de um modo geral, pois através da segurança jurídica atinge-se o escopo da paz social, com a eliminação de litígios, que não interessam à sociedade, de um modo geral. Da mesma forma, a coisa julgada põe termo à atividade estatal judiciária sobre determinada lide, uma vez que não interessa à sociedade que se movimente eternamente o aparato estatal de solução de controvérsias, não só por motivos de ordem financeira, bem como para que não se sobrecarregue demasiadamente o Judiciário, caso contrário, este se veria sempre às voltas com demandas infindáveis ou sendo instado a apreciar a mesma lide, repetidas vezes.

Todavia, como asseverado anteriormente, no capítulo no qual tratou-se da jurisdição, o valor da segurança é somente um dos escopos da jurisdição, tendo outros ao seu lado, de igual (ou maior) relevância, destacando-se, também o valor justiça das decisões. Ambos devem estar presentes e devem igualmente ser sopesados na entrega da prestação jurisdicional. No entanto, por opção do sistema, a partir de um certo momento, ao valor da justiça se sobrepõe o da segurança e, a partir desse momento, a lei impede que se prossiga na investigação da verdade, pondo termo à atividade cognitiva 31 .

Portanto, a coisa julgada atinge também as decisões injustas, tornando-as igualmente imutáveis, dado que, para o bom funcionamento do sistema, não se pode admitir a revisão do julgado sob o argumento de haver injustiça na sentença, pois, entendimento em sentido contrário, iria contra a essência do instituto. O sistema prevê

\footnotetext{
${ }^{29}$ CANOTILHO, J. J. Gomes. Direito constitucional e teoria da constituição, cit., p. 263.

${ }^{30}$ Também nesse sentido, TALAMINI, Eduardo. Coisa julgada e sua revisão, cit., esp. p. 61 e ss.

${ }^{31}$ Neste sentido, BARBOSA MOREIRA, José Carlos. Considerações sobre a causa de pedir na ação rescisória. In: Temas de direito processual: $4^{\mathrm{a}}$ série. São Paulo: Saraiva, 1988. p. 243.
} 
mecanismos ordinários para revisão de decisões injustas (v.g. os recursos), porém, se tais mecanismos falharem, ainda assim, a decisão torna-se imutável, a fim de não se eternizar litígios, tudo em prol do escopo social do processo (eliminação dos conflitos, de forma justa).

Porém, recentemente ganhou relevo na doutrina e jurisprudência, tendência no sentido de se desconsiderar a coisa julgada (denominada "relativização da coisa julgada”), quando a injustiça da decisão seja grave, e contrarie princípios fundamentais, igualmente relevantes ao sistema, sobrepondo-se o valor justiça ao da segurança jurídica, como adiante se verá.

\section{III.4. Caráter público da coisa julgada}

A coisa julgada é matéria de caráter público, pois foi instituída no sistema por questões de ordem política e institucional ${ }^{32} \mathrm{e}$, a partir do momento em que a jurisdição passou a ser uma função pública, através da qual o Estado exerce o seu poder, o meio de solução de controvérsia deixou de ter um caráter eminentemente privado, no qual estão em jogo somente os interesses das partes, assumindo um aspecto público, visto que o Estadojuiz faz parte da relação jurídica processual, instado, através da demanda, a proferir seu julgamento, pacificando as partes e eliminando o conflito. Essa participação estatal confere o caráter público à solução entregue pela jurisdição, assim como à imunização dos efeitos produzidos pela entrega da prestação jurisdicional.

Assim, a jurisdição, e consequentemente, o processo, assume um caráter eminentemente público 33 , sendo inerente ao sistema, como já visto, a figura da coisa julgada, uma vez que não interessa nem ao Estado, nem à sociedade, de um modo geral, que os conflitos se multipliquem e não cheguem a um termo, sendo a coisa julgada um instrumento de segurança e pacificação social, colocando um termo aos litígios postos diante do Estado-juiz para serem apreciados.

\footnotetext{
${ }^{32}$ "Nesse sentido, além de garantia individual, a coisa julgada funciona como garantia institucional." TALAMINI, Eduardo. Coisa julgada e sua revisão, cit., p. 67.

${ }^{33}$ "A tendência a dar maior realce ao papel do juiz corresponde, como bem se compreende, a uma acentuação mais forte do caráter publicístico do processo civil.” BARBOSA MOREIRA, José Carlos. As bases do direito processual civil. In: __ . Temas de direito processual: (primeira série). São Paulo: Saraiva, 1988. p. 11.
} 
Em razão dessa índole pública que assume o instituto da coisa julgada, que vem regrada no nosso ordenamento jurídico pelos artigos 267 , VI e $\S 3^{\circ}$ e 301 , VI e $\S 4^{\circ}$, do Código de Processo Civil, o que permite, inclusive, que a questão seja conhecida de ofício pelo juiz, em qualquer tempo ou grau de jurisdição, as partes não podem transigir sobre a coisa julgada, nem sequer podem abrir mão dela, ou seja, a parte vencedora não pode concordar em abrir mão do julgamento anterior e consentir em um novo julgamento ${ }^{34}$, justamente em razão do interesse público que permeia o instituto, que visa evitar a perenização dos litígios, em prol da segurança e da pacificação social, não se podendo movimentar toda a máquina judiciária para apreciar novamente questões já amparadas pela auctoritas rei judicatae.

\section{III.5. Limites}

No que tange aos limites subjetivos, em consonância com o disposto no artigo 472 do Código de Processo Civil, a sentença faz coisa julgada somente envolvendo as partes entre as quais é dada, não podendo atingir terceiros. Tal preceito é decorrência do princípio do devido processo legal, pois não seria lícito que terceiros que não tivessem assegurado a sua participação no processo em contraditório, com possibilidade de produzir provas de maneira ampla, tivessem que sofrer algum prejuízo da decisão dada entre terceiros, sendo essa a regra geral 35 . Porém, a questão dos limites subjetivos da coisa julgada é bastante controvertida na doutrina e seus questionamentos vêm de longa data.

A noção de que a coisa julgada não pode beneficiar nem prejudicar terceiros, devendo produzir efeitos somente inter partes, vem desde a mais antiga tradição romana ("Saepe constitutum est, res inter alios iudicatas aliis non praeiudicare") 36 . O ponto de partida, portanto, para se verificar o alcance subjetivo da coisa julgada, é a participação das partes em contraditório, assegurando-lhes a ampla defesa, em processo judicial, em que lhes sejam outorgadas oportunidades em paridade de condições. Nesses

\footnotetext{
${ }^{34}$ Neste sentido, Humberto Theodoro Júnior, in Curso de direito processual civil. Rio de Janeiro: Forense, 2000. v. 1: "A coisa julgada é instituto processual de ordem pública, de sorte que a parte não pode abrir mão dela.” (p. 466).

${ }^{35}$ art. $5^{\circ}$, LV da Constituição Federal.

"Muitas vezes se determinou que a coisa julgada em relação a uns não prejudica a outros". In CRUZ E TUCCI, José Rogério. Limites subjetivos da eficácia da sentença e da coisa julgada civil. São Paulo: Ed. Revista dos Tribunais, 2006. p. 46.
} 
termos, para verificação dos limites subjetivos, deve-se considerar paridade de tratamento e a existência de contraditório, em um devido processo legal (due process of law).

Liebman esclareceu a polêmica estabelecendo uma primeira diferenciação entre a eficácia da sentença em relação a terceiros e o estabelecimento da coisa julgada concernente a terceiros. O cerne de seu pensamento é de que a coisa julgada, não sendo um efeito da sentença, não o é nem para as partes e muito menos para terceiros, que, corretamente, não devem "sofrer os efeitos (ainda que reflexos ou secundários) da coisa julgada"37, como equivocadamente entendia a doutrina da época. A coisa julgada, segundo afirma Liebman, vigora somente entre as partes que atuaram no processo em contraditório, porém, os efeitos naturais da sentença devem ser observados e reconhecidos por todos, porque a lei quer que tais efeitos se verifiquem 38 . Nas sempre esclarecedoras palavras de Liebman: "Por isso, enquanto, abstratamente, estão todas as pessoas submetidas à eficácia da sentença, praticamente lhe sofrem os efeitos aqueles em cuja esfera jurídica entra mais ou menos diretamente o objeto da sentença (...). Entre partes e terceiros só há esta grande diferença: que para as partes, quando a sentença passa em julgado, os seus efeitos se tornam imutáveis, ao passo que para os terceiros isso não acontece."39.

Em relação aos limites objetivos, a coisa julgada material, por expressa disposição legal, atinge somente o petitum, não imunizando os motivos da sentença, através do qual o juiz decide as questões de fato e de direito, bem como as questões prejudiciais (art. 469 do CPC), onde o juiz exerce sua atividade lógica, que ampara a sua conclusão. Assim, só fica imunizada pela auctoritas rei judicatae a resposta ao pedido veiculado pelo autor, ou seja, o dispositivo, ou, conforme a lição de Liebman, o comando pronunciado pelo juiz 40 . Caso as partes pretendam que esta atinja também alguma questão prejudicial, podem requerer expressamente, por ação declaratória incidental, que esta faça parte do objeto da lide, integrando o thema decidendum, tornando-se, dessa forma, apta a fazer coisa julgada material, nos termos do artigo 470 do Código de Processo Civil.

\footnotetext{
${ }^{37}$ LIEBMAN, Enrico Tullio. Eficácia e autoridade da sentença e outros escritos sobre a coisa julgada, cit., p. 86.

${ }^{38}$ Eficácia e autoridade da sentença e outros escritos sobre a coisa julgada, cit., esp. p. 121 e ss.

${ }^{39}$ Eficácia e autoridade da sentença e outros escritos sobre a coisa julgada, cit., p. 125 e ss.

${ }^{40}$ Eficácia e autoridade da sentença e outros escritos sobre a coisa julgada, cit., p. 55.
} 
Segundo autorizada doutrina, a finalidade do instituto é a de se evitar o conflito prático de julgados 41 , pois, se assim não fosse, não haveria como se implementar duas decisões praticamente conflitantes entre si (por exemplo: uma decisão que pronunciasse a separação judicial de um casal e outra que negasse o direito à separação deveriam os cônjuges permanecer casados ou não?). Porém, o instituto não tem por escopo a eliminação de meros conflitos teóricos, que não impediriam a implementação prática das decisões, visto que "a jurisdição não se exerce para fixar teses jurídicas nem para a descoberta da verdade dos fatos como um objetivo em si próprio"42. Assim, o motivo das decisões, onde o juiz estabelece a verdade dos fatos e fundamenta juridicamente a sua decisão (acolhendo ou rejeitando a tese das partes), não é apta a fazer a coisa julgada material, pois esta visa a "proteger resultados, não raciocínios"43.

\footnotetext{
${ }^{41}$ Neste sentido: DINAMARCO, Cândido Rangel. Instituições de direito processual civil. 6. ed. São Paulo: Malheiros Ed., 2009. v. 3, p. 318 e ss.

${ }^{42}$ DINAMARCO, Cândido Rangel. Instituições de direito processual civil, cit., v. 3, p. 319.

${ }^{43}$ DINAMARCO, Cândido Rangel. Instituições de direito processual civil, cit., p. 322.
} 
B - PARTE SEGUNDA 


\section{GENERALIDADES SOBRE OS MEIOS DE IMPUGNAÇÃO DAS DECISÕES JUDICIAIS: RECURSOS, MANDADO DE SEGURANÇA; AÇÃO ANULATÓRIA}

Os meios de impugnação, de uma forma geral, não são conceitos exclusivos do direito processual, pois não apenas os atos judiciais podem ser impugnados, também se pode impugnar um ato administrativo, uma deliberação em assembléia etc, assim, é à teoria geral do direito que pertence a categoria genérica de impugnação 44 .

No que concerne ao direito processual, o sistema prevê uma série de mecanismos que visam à revisão das decisões judiciais, a fim de garantir maior segurança e justiça das decisões, que se operam mediante a provocação do interessado, acarretando novo pronunciamento sobre a matéria impugnada, possibilitando a correção de possíveis erros contidos no provimento judicial entregue. Tal se dá, evidentemente, em razão de que a conduta do ser humano não está isenta de falhas. Ademais, sabendo já de antemão que sua decisão poderá ser revista por outro órgão, o prolator da decisão se cercará de maiores cuidados na entrega da prestação jurisdicional, melhorando a qualidade da tutela oferecida ao final.

Demais disso, é da natureza humana não se conformar com as contrariedades que enfrenta, sendo natural a manifestação de seu inconformismo diante de situações adversas e, nessa medida, até para conferir maior segurança e legitimidade às suas decisões, o sistema prevê mecanismos através dos quais a parte contrariada por uma decisão judicial pode expressar legitimamente a sua irresignação, tornando mais fácil, pela parte vencida, a aceitação das decisões preferidas pelo órgão judicial quando pode expor (e, especialmente, ter analisadas) as razões de sua discordância, tornando o processo um mecanismo legítimo de eliminação de conflitos sociais 45 .

Dificilmente o direito processual cumpriria sua missão de pacificação social se atentasse contra os impulsos naturais do ser humano, tal qual o da possibilidade de

\footnotetext{
${ }^{44}$ Neste sentido, Satta, Diritto processuale civile. Padova: Cedam, 1950. p. 287.

${ }^{45}$ Como bem observado pela doutrina, "[...] l' "impugnazione" assume tuttavia qualificazioni più precise, configurandosi come un rimedio o uno strumento che ha la funzione di asicurare il controllo della legittimità e della giustizia della decisione". (COMOGLIO, Luigi Paolo; FERRI, Corrado; TARUFFO, Michele. Lezioni sul processo civile. Bologna: Il Mulino, 1998. p. 775).
} 
manifestar seu inconformismo frente às adversidades da vida, havendo até quem chegue a afirmar certa "necessidade psicológica" da aludida manifestação de insatisfação 46 .

Destarte, a doutrina afirma que os meios de impugnação exercem uma função de controle da decisão contestada, aspirando a um provimento justo, correto e não mais sujeito à contestação 47 , bem como que os meios de impugnação cumprem uma dupla função: de um lado, satisfazer a exigência de reexame do julgamento e, de outro, através do exaurimento dessa série limitada de reexame, alcançar a certeza, eliminando a controvérsia então existente 48 .

Os meios de impugnação das decisões judiciais remontam aos primórdios da organização judiciária, tendo surgido antes mesmo dos remédios mais utilizados atualmente como meio de impugnação, os recursos, (sendo o mais típico deles, a apelação) ${ }^{49}$, pois, como anteriormente asseverado, as manifestações de descontentamento com situações adversas são inerentes à condição humana e, sendo assim, os meios de impugnação das decisões judiciais originaram-se desse natural inconformismo do homem, conferindo maior legitimidade às decisões e ao Judiciário, na medida em que propicia ao vencido manifestar sua irresignação o que, certamente, não pode ser feito de forma ilimitada, pois, para que igualmente atinja seu fim pacificador, é curial que a tutela jurisdicional se revista, a partir de um momento estabelecido por política legislativa, de um caráter de definitividade, pondo um fim à controvérsia.

Existem vários meios de exercer esse inconformismo, dos quais os meios de impugnação são gênero, sendo que a doutrina tradicional agrupa-os em duas espécies: as

\footnotetext{
${ }^{46}$ LIMA, Alcides de Mendonça. Introdução aos recursos cíveis. São Paulo: Ed. Revista dos Tribunais, 1976. n. 116, p. 127 e ss.

${ }^{47}$ COMOGLIO, Luigi Paolo; FERRI, Corrado; TARUFFO, Michele. Lezioni sul processo civile, cit., p. 775.

${ }^{48}$ MANDRIOLI, Crisanto. Corso di diritto processuale civile: il processo di cognizione. Torino: G. Giappichelli, 2000. v. 2, p. 238.

${ }^{49}$ Confirmando a existência de meios de impugnação da sentença desde épocas mais remotas do direito romano, Moacyr Lobo da Costa e Luiz Carlos de Azevedo, in Estudos de história do processo: recursos. Osasco: FIEO, 1996, ressaltam que: "Mas, se assim era, sempre se procurou, por seu turno, encontrar algum remédio para contornar tal impossibilidade, sem que esses expedientes, muito embora jurídicos, constituíssem apelação, principalmente porque inexistia, por essa época, hierarquia administrativa e jurídica capaz de estruturar esta última modalidade recursal." No mesmo sentido, Alcides de Mendonça Lima, afirma que: "Entretanto, se generalizarmos o conceito, não ficando adstrito apenas à apelação, não será difícil conceber a possibilidade de ser usado um remédio que obstasse os efeitos da sentença, quer por via da declaração de sua nulidade, quer por intermédio da intercessio ou da restitutio in integrum, ainda que a última fosse autorizada em casos excepcionais." (LIMA, Alcides de Mendonça. Introdução aos recursos cíveis, cit., p. 4 e ss.).
} 
ações autônomas de impugnação e os recursos 50 . A ação rescisória é o exemplo mais característico das ações de impugnação autônomas.

A classificação dos meios de impugnação como recurso ou ação autônoma depende de opção de política legislativa, uma vez que, em razão do princípio da taxatividade dos recursos, só são classificados como tais aqueles elencados no rol do artigo 496 do Código de Processo Civil.

A principal distinção existente entre os recursos e os meios autônomos de impugnação é o fato de que o recurso não instaura um novo processo ou nova relação processual, sendo dominante na doutrina o entendimento de que o recurso é um mero desdobramento ou extensão do direito de ação 5152 , enquanto os meios autônomos de impugnação do ato judicial instauram, sempre, um novo processo e uma relação processual autônoma.

Outra diferença existente entre os recursos e os meios autônomos de impugnação judicial é o fato de que, no processo civil brasileiro, o recurso sempre impede a formação da coisa julgada, e os autônomos de meios de impugnação, de uma forma geral, são manejados após a ocorrência do trânsito em julgado. Porém, esta não é uma condição necessária, haja vista que, o mandado de segurança (outro exemplo de meio autônomo de impugnação) contra ato judicial pressupõe justamente a inexistência da res iudicata. Essa já era a orientação jurisprudencial contida na Súmula 268 do Supremo Tribunal Federal ${ }^{53}$, quando da anterior lei do mandado de segurança e, encampando o entendimento jurisprudencial já consolidado, a nova lei do mandado de segurança (Lei $n^{0} 12.016 / 09$ ), determina expressamente a impossibilidade de se manejar o mandado de segurança em face de decisão transitada em julgado 5455 . Portanto, não obstante a existência de trânsito

\footnotetext{
${ }^{50}$ Ver por todos: BARBOSA MOREIRA, José Carlos. Comentários ao Código de Processo Civi, cit., n. 134, p. 229 e ss.

${ }^{51}$ Neste sentido: BARBOSA MOREIRA, José Carlos. Comentários ao Código de Processo Civi, cit., n. 137, p. 235 e ss.

${ }^{52}$ Em sentido contrário, ASSIS, Araken de. Manual dos recursos. São Paulo: Ed. Revista dos Tribunais, 2007. n. 2, p. 35 e ss., opinando tratar-se de pretensão autônoma, exercida simultaneo processu.

${ }^{53}$ Súmula 268/STF: "Não cabe mandado de segurança contra decisão judicial com trânsito em julgado."

${ }^{54}$ Art. $5^{\circ}$, III, da Lei n ${ }^{\circ} 12.016 / 09$.

${ }^{55}$ Como bem observa Flávio Yarshell, não se admite o mandado de segurança como sucedâneo da ação rescisória, não podendo aquele ser interposto contra ato judicial com trânsito em julgado (Ação rescisória: juízos rescindente e rescisório. São Paulo: Malheiros Ed., 2005. p. 84). Deveras, o meio típico para impugnação de decisão transitada em julgado, previsto taxativamente na lei, é a ação rescisória, não se admitindo a utilização de outros meios para se atingir o mesmo fim, face a excepcionalidade desse meio típico, que põe em xeque a segurança jurídica imposta pelo sistema. Em sentido contrário, ainda que
} 
em julgado da decisão impugnada seja uma das diferenciações com o recurso, não se trata de regra absoluta, diante da vedação do manejo do mandado de segurança em face de tais decisões, não sendo este o traço mais característico desse meio de impugnação.

Não obstante, a sensível redução da utilização do mandado de segurança contra ato judicial após as modificações implementadas pelas reformas no recurso de agravo de instrumento, possibilitando a atribuição de efeito suspensivo e do denominado “efeito ativo", a doutrina e a jurisprudência 56 entendem cabível o mandado de segurança, especialmente quando se tratar de decisão teratológica ou contra flagrante violação de lei; contra a qual não caiba recurso 57 , ou ainda, quando, a despeito da decisão ser passível de causar à parte lesão grave ou de difícil reparação, a lei impõe o emprego do agravo retido. Despiciendo dizer que, para viabilidade do mandado de segurança, devem estar presentes os requisitos legais e constitucionais para o seu manejo.

Impende ainda ressaltar que, nas hipóteses de o recurso a ser interposto se mostrar inócuo ou ficar caracterizada a manifesta ilegalidade da decisão atacada, os Tribunais têm afastado a incidência da Súmula 267 do Supremo Tribunal Federal que reputa incabível o mandado de segurança contra ato judicial passível de recurso ou correição ${ }^{58}$. Como bem observa Flávio Luiz Yarshell, tal entendimento não se aplica quando o autor pleitear tutela de urgência e, não só seja indeferida a medida antecipatória, como também extinto o processo sem julgamento do mérito, pois, em tais casos, o mandamus, por si só, não é apto a reparar a situação integralmente, sendo de rigor, a interposição do recurso cabível em conjunto com o mandado de segurança 59 , para possibilitar o prosseguimento da ação principal.

A ação anulatória é apontada como outro meio típico de ação de impugnação das decisões judiciais, que a doutrina majoritária entrevê na figura prevista no

somente para hipóteses extremas, PARENTE, Eduardo Albuquerque. Institutos equivalentes à ação rescisória. Revista de Processo, São Paulo, ano 28, n. 112, p. 124-150, out./dez. 2003.

${ }^{56}$ Somente para citar a guisa de exemplo: REsp. $\mathrm{n}^{\mathrm{o}} 1.125 .652$, rel. Min. Mauro Campbell Marques, DJe 20/09/2010; $\mathrm{RMS}^{\circ}$ 30.115/SP, rel. Min. Humberto Martins, DJe 19/08/2010; RMS 29.391/GO, rel. Min. João Otávio de Noronha, DJe 27/05/2010.

${ }^{57}$ A exemplo da regra contida no parágrafo único do artigo 527, do Código de Processo Civil.

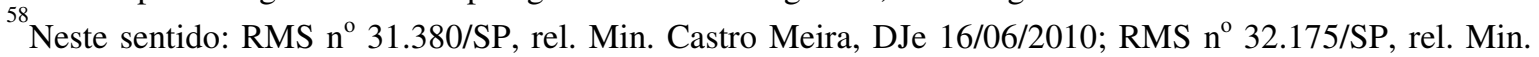
Herman Benjamin, DJe 16/09/2010; RMS nº 29.391/GO, rel. Min. João Otávio de Noronha, DJe 27/05/2010.

${ }^{59}$ YARSHELL, Flávio Luiz. Ação rescisória: juízos rescindente e rescisório, cit., n. 5, p. 34-40. 
artigo 486 do Código de Processo Civil 60 , não obstante a precária redação que possui o citado texto de lei, que faz menção à "rescisão" dos atos judiciais e não anulação. De fato, a ambígua redação do artigo em questão suscita muitas dúvidas aos operadores do direito. Nesse contexto, pode-se afirmar que o entendimento majoritário, tanto da doutrina 61 como da jurisprudência 62 , quanto ao sentido que se deve emprestar ao referido dispositivo é de que este se refere a "ato da parte" praticado em juízo, quando diz "ato judicial”. Assim, não é a sentença que é anulada, mas o ato homologado (ato da parte).

A imprecisão terminológica é patente, pois não se afigura correto falar de ato judicial "que não depende de sentença"; ou o ato judicial é sentença ou não é. Ademais, como já adiantado, não se pode cogitar de ação rescisória contra ato judicial (na redação do mencionado artigo, "que não dependa de sentença ou em que esta for meramente declaratória") que não seja sentença de mérito, nos termos do caput do artigo 485, do Código de Processo Civil. Eis, portanto, a razão primordial porque não se pode considerar a ação do artigo 486 do Código de Processo Civil como rescisória, cuidando-se, como visto, de ação anulatória.

Outro argumento que reforça o entendimento de que através da ação anulatória do artigo 486 do Código de Processo Civil não se desconstitui a sentença, mas o ato homologado é de que, quando o Código quis prever uma forma de desconstituir as sentenças homologatórias, fê-lo de forma expressa (artigos 485, VIII e 1.029), não se concebendo poder haver dois meios para desconstituir a mesma decisão 63 .

Com razão Berenice Soubhie Nogueira Magri, afirma que "[...] a ação anulatória do art. 486 do CPC tem por fundamento vício no direito material, atingindo diretamente o ato das "partes" que o juiz homologou ou não, enquanto a ação rescisória

\footnotetext{
${ }^{60}$ Contra, entendendo tratar-se de ação rescisória, Pontes de Miranda, in Tratado da ação rescisória das sentenças e de outras decisões. Rio de Janeiro: Forense, 1976. parte III, capítulo III, p. 405-445.

${ }^{61}$ Ver por todos, BARBOSA MOREIRA, José Carlos. Comentários ao Código de Processo Civil, cit., n. 91 92, p. 156-161 e Berenice Soubhie Nogueira Mgri, “Ação anulatória: art. 486 do CPC”, n. 2, p. 49 e ss.

${ }^{62}$ Confira-se: RE n ${ }^{0}$ 100.466/SP, rel. Min. Djaci Falcão, DJ 28/02/86; REsp. n ${ }^{\circ}$ 13.102/SP, rel. Min. Athos Carneiro, DJ 08/03/93; REsp. no 450.431/PR, rel. Min. Luiz Fux, DJ 20/10/03; REsp. no 776.242/SC, rel. Min. Carlos Alberto Menezes Direito, DJ 26/02/07.

${ }^{63}$ Segundo anota Barbosa Moreira, para as hipóteses de sentença homologatória que estão previstas no artigo 485, VIII, do CPC, há de se entender que, na pendência do processo, isto é, antes do trânsito em julgado, deve-se utilizar a ação anulatória do art. 486, após o trânsito em julgado só é possível a utilização da ação rescisória, desde que presentes os demais requisitos (BARBOSA MOREIRA, José Carlos. Comentários ao Código de Processo Civi, cit., n. 92, p. 160 e ss.).
} 
decido o próprio julgamento anterior, i.e, o "ato judicial" que é imperfeito"64, esclarecendo com propriedade a principal diferença entre os dois meios autônomos de impugnação que se assemelham e causam confusão em razão das incongruências terminológicas apontadas.

Ainda quanto às "decisões que não dependem de sentença", poder-se-ia entender como as demais decisões proferidas em juízo (decisões interlocutórias). A tese, porém, não se sustenta, pois tais decisões são atacáveis por meios próprios (recursos), e não é possível conceber que tais decisões possam ser impugnadas indefinidamente, por ação anulatória, a uma, porquanto existe o meio próprio e, a duas, por ter-se operado a preclusão, sendo inconcebível admitir-se que estas poderiam ser impugnadas, por ação anulatória, a qualquer tempo, tornando os feitos infindáveis.

Em suma, pode-se dizer que a ação anulatória do artigo 486 do Código de Processo Civil constitui um meio autônomo de impugnação das decisões judiciais “indireto", na medida em que se presta a atacar o ato da parte homologado judicialmente e, somente via reflexa, acaba por invalidar a decisão homologatória, visto que, não subsistindo o conteúdo da homologação, não há que permanecer hígida a decisão continente.

\footnotetext{
${ }^{64}$ MAGRI, Berenice Soubhie Nogueira. Ação anulatória: art. 486 do CPC. São Paulo: Ed. Revista dos Tribunais, 2004. p. 194.
} 


\section{A AÇÃo RESCISÓRIA COMO MEIO EXCEPCIONAL DE IMPUGNAÇÃO}

Como anteriormente afirmado, um dos escopos da prestação jurisdicional é justamente o de "eliminar conflitos mediante critérios justos" (escopo social) e tal objetivo é alcançado com a entrega definitiva da prestação jurisdicional, eliminando de forma peremptória o conflito anteriormente instaurado. Enquanto pendente a lide, perdura um sentimento de insegurança e indefinição no espírito dos litigantes e, de um modo geral, na sociedade, o que não é desejável.

A eliminação do conflito mediante critérios justos dissemina maior segurança na sociedade. E para que o conflito seja suprimido de forma definitiva, o sistema dispõe de mecanismos a fim de evitar discussões infindáveis, que não interessam à sociedade ou ao Judiciário, dotando o resultado obtido com o processo (ferramenta concebida para eliminação de conflitos) de certa estabilidade e imutabilidade. Um desses mecanismos é justamente a coisa julgada que impede, a partir de certo ponto, que a questão volte a ser debatida, impedindo qualquer discussão sobre a mesma lide.

O sistema processual, por sua vez, prevê meios de impugnação "ordinários" das decisões proferidas no processo, que são os recursos 65 , ou seja, são a forma mais comum de impugnar as decisões, possuindo maior âmbito de utilização e de abrangência. Tanto é assim que a maior parte da doutrina considera os recursos como mero desdobramento ou extensão do direito de ação 66 , falando-se, inclusive, no princípio do duplo grau de jurisdição, que a doutrina vislumbra estar inserido no artigo $5^{\circ}, \mathrm{LV}$, da Constituição Federal 67 , como meio inerente ao princípio do contraditório e da ampla defesa, necessário ao devido processo legal.

A ação rescisória, por seu turno, visa justamente desconstituir decisão de mérito transitada em julgado, ou seja, aquela que decidiu a causa de modo definitivo,

\footnotetext{
${ }^{65}$ Nestes termos, Flávio Yarshell, In Tutela jurisdicional, cit., n. 9.2, p 150.

${ }^{66}$ Ver por todos, BARBOSA MOREIRA, José Carlos. Comentários ao Código de Processo Civil, cit., n. 137, p. 235 e ss.

${ }^{67}$ Conforme PINTO, Nelson Luiz. Manual dos recursos cíveis. São Paulo: Malheiros Ed., 1999. n. 3.2, p.78.
} 
pondo fim ao litígio, pacificando as partes, e que, portanto, atingiu, em tese 68 , plenamente a sua finalidade, sendo um meio de ataque à coisa julgada, um dos pilares do nosso ordenamento jurídico de tamanha importância, haja vista a proteção constitucional de que goza (art. $5^{\circ}$, XXXVI, da Constituição Federal), sendo, justamente em razão disso, meio excepcional de ataque às decisões, já revestidas da coisa julgada.

Exatamente por isso a ação rescisória possui requisitos rígidos e restritos, são eles: prazo decadencial de 2 (dois) anos (art. 495, do CPC); condicionamento da propositura da ação a depósito prévio de $5 \%$ (cinco por cento) do valor da causa a título de multa no caso de julgamento unânime pela inadmissibilidade ou improcedência da demanda (art. 488, II, do CPC), como forma de desestímulo da utilização indevida e de abusos; causas de pedir taxativamente previstas em lei69 (incisos I ao IX do art. 485 CPC), por opção política do legislador pátrio, que elegeu alguns vícios que entendeu serem graves o suficiente para macular a decisão definitivamente entregue e, não se podendo, por isso, ampliá-las ou interpretá-las de forma extensiva.

O caráter excepcional da medida em apreço remonta a seus antecedentes históricos, que provêm das mais variadas fontes. Com efeito, a nossa ação rescisória é uma condensação de vários institutos utilizados de forma excepcional como meios de impugnação das decisões proferidas no bojo dos procedimentos instaurados para solução dos conflitos existentes na sociedade da época.

Não há um consenso na doutrina acerca das origens históricas da nossa ação rescisória, sendo mais comumente apontados como germe os institutos da querela nullitatis e da restitutio in integrum 70 . Ressaltando o caráter excepcional da última figura, Moacyr Lobo da Costa assevera: "Nesses casos a atuação do pretor assumia a natureza de um auxilium extraordinarium a favor da parte lesada, quando inexistissem outros meios

\footnotetext{
${ }^{68} \mathrm{O}$ que só não terá efetivamente ocorrido caso se constate efetivamente algum dos vícios previstos nos incisos do artigo 485, do Código de Processo Civil, afastando a entrega jurisdicional da justiça das decisões.

${ }^{69}$ Segundo leciona Flávio Yarshell, a ação rescisória "é indicada, pela autorizada doutrina, como sendo uma "ação típica", precisamente pela taxatividade dos modelos que, em tese, são aptos a compor a respectiva "causa petendi"” E continuando, explica que a dita tipicidade restringe-se ao juízo rescindente. In Tutela jurisdicional, cit., n. 8, p. 74 e n. 9.1, p. 150.

${ }^{70}$ A respeito do tema, conferir as lições de COSTA, Moacyr Lobo. A revogação da sentença: gênese e genealogia. São Paulo: Ícone, 1995; PONTES DE MIRANDA, Francisco Cavalcanti. Tratado da ação rescisória das sentenças e de outras decisões, cit., esp. p. 74 e 89 e ss.; e BARBOSA MOREIRA, José Carlos. Comentários ao Código de Processo Civil, cit., n. 66, p. 101 e ss.
} 
ordinários para impedir as danosas conseqüências daqueles atos civilmente válidos $[\ldots]^{, 71}$.

Também apontando o caráter excepcional do remédio em questão, Pontes de Miranda observa que, "A ação rescisória é remédio jurídico processual extraordinário, razão por que, se a sentença não existe, ou é nula, cabe ao juiz declarar-lhe a inexistência, ou decretar-lhe a nulidade em vez de rescindi-la". Portanto, a medida, em razão de seu caráter excepcional, só poderá ser utilizada nos estreitos casos taxativamente previstos na lei processual e limitado às hipóteses legais 72 .

Enfatizando, ainda, o caráter excepcional da presente medida, que visa atacar a coisa julgada, a qual já foi afirmada como sendo a "sanatória geral" dos vícios do processo, somente sobrevivem à coisa julgada alguns daqueles entendidos pelo legislador como sendo de natureza tão grave, a justificar a possibilidade de novo julgamento sobre a matéria, pois os vícios comprometem a própria existência do processo 737475 .

Assim, a índole excepcional desse meio de impugnação das decisões judiciais não permite que se dê interpretação analógica aos termos da lei, nem que seu uso ocorra fora das estritas hipóteses legais de cabimento (taxatividade das causas de pedir

\footnotetext{
${ }^{71}$ E continua o renomado autor: "A palavra extraordinarium, esclarece Scialoja deve ser aqui entendida em duplo sentido: extraordinário é o remédio porque o pretor não se limita a ordenar o juízo, mas ele próprio assume o conhecimento da controvérsia; extraordinário é também porque se emprega quando faltem todos os outros meios processuais extraordinários." COSTA, Moacyr Lobo. A revogação da sentença: gênese e genealogia, cit., p. 26.

${ }^{72}$ Ainda sobre o tema, Flávio Yarshell afirma: “[...] reafirmado o caráter excepcional da ação rescisória, que não se presta simplesmente a corrigir injustiça da decisão, tampouco se revelando simples abertura de uma nova instância recursal, ainda que de direito.”. In Ação rescisória: juízos rescindente e rescisório, cit., p. 323.

${ }^{73}$ LIEBMAN, Enrico Tullio. Citação inicial. Falta - nulidade absoluta da sentença, embora já transitada em julgado - Parecer. Revista dos Tribunais, São Paulo, ano 33, v. 152, p. 443-446, nov. 1944.

${ }^{74}$ Ainda no que concerne ao efeito saneador da coisa julgada, Chiovenda, ao registrar que os vícios da sentença podem ser de duas naturezas, quais sejam, injustiça e nulidade, ressalta que: "Em primeiro lugar, é próprio do instituto da coisa julgada moderna que se cubra a injustiça da sentença com a passagem em julgado da sentença mesma. No que tange às nulidades, variam os sistemas: em Roma, podia-se, sempre, opor à res iudicata a nulidade da sentença, sem necessidade de impugnação especial." In CHIOVENDA, Giuseppe. Instituições de direito processual civil. Tradução da 2. ed., por J. Guimarães Menegale. São Paulo: Saraiva, 1965. v. 3, n. 379, p. 200.

${ }^{75}$ Conforme anota Liebman ao comentar as "Instituições..." de Chiovenda, "O remédio concedido às partes contra uma sentença eivada de defeitos muito graves, oscilou, pois, no curso do tempo, entre figuras muito diversas entre si. Como ponto de partida assinala-se historicamente a sentença nula em absoluto. A exigência de maior estabilidade das relações jurídicas induziu a uma evolução que, se bem não idêntica em todos os países, apresenta em toda parte a mesma tendência: aqueles vícios, por graves que fossem, de insanáveis que eram, sanáveis se tornaram, e a sentença, a despeito do vício, não é nula de pleno direito, antes é plenamente eficaz, enquanto não vem a ser anulada por meio do remédio adequado, e conserva-se inatacável após o decurso dos prazos estabelecidos para o exercício desse remédio; em outras palavras, a sentença viciada tornou-se simplesmente anulável." (nota à p. 202).
} 
previstas em lei). Essa excepcionalidade decorre diretamente da função que o remédio desempenha no sistema, consistente na rescisão da decisão de mérito coberta pela coisa julgada, um dos pilares do nosso ordenamento jurídico 76 .

\section{II.1. Função e escopos da ação rescisória}

A ação rescisória, conforme expressa disposição legal, visa a atacar a sentença de mérito coberta pela coisa julgada material, nas hipóteses elencadas nos incisos I a IX, do artigo 485 do Código de Processo Civil, tratando-se de medida excepcional, entendendo a doutrina tradicional, que os incisos do artigo 485 devem ser interpretados sem possibilidade de ampliações 77 (por ser o rol taxativo), o que não significa, segundo autorizada doutrina, que não se possa dar interpretação extensiva aos termos da lei, a fim de revelar o verdadeiro alcance da norma 78 , pois, o que é vedado é o aviamento da ação rescisória por causa de pedir que não esteja taxativamente prevista nos incisos do artigo 485 do Código de Processo Civil.

Examinando-se os incisos do artigo 485 do Código de Processo Civil, verifica-se que a ação rescisória visa resguardar o valor da justiça das decisões, atenuando o princípio da segurança jurídica conferida pela coisa julgada, visto que permite a revisão do caso soberanamente julgado, em razão de vícios que entende serem de tal magnitude, de forma a macular o provimento jurisdicional de grave defeito que entende suficiente para que se proceda a tal revisão 7980 .

\footnotetext{
${ }^{76}$ Porém, nem sempre a ação rescisória se prestará a atacar a coisa julgada, pois, se esta for proposta com base no inciso IV, do art. 485, do CPC, a ação rescisória terá por escopo justamente proteger a coisa julgada anterior.

${ }_{77}^{77}$ Neste sentido: DINAMARCO, Cândido Rangel. Instituições de direito processual civil, cit., v. 3, p. 723.

${ }^{78}$ Nestes termos, BARBOSA MOREIRA, José Carlos. Comentários ao Código de Processo Civil, cit., n. 89, p. 154 e YARSHELL, Flávio Luiz. Ação rescisória: juízos rescindente e rescisório, cit., n. 95, p. 294 e TALAMINI, Eduardo. Coisa julgada e sua revisão, cit., n. 3.4, p. 142.

${ }^{79}$ Sobre o tema, cabe transcrever as pertinentes lições do professor Dinamarco: "Uma boa ordem processual não é feita somente de segurança e das certezas do juiz. Ela vive de certezas, probabilidades e riscos. Onde houver razões para decidir ou para atuar com apoio em meras probabilidades, sendo estas razoavelmente suficientes, que se renuncie à obsessão pela certeza, correndo algum risco de errar, desde que se disponha de meios aptos a corrigir os efeitos de possíveis erros". (DINAMARCO, Cândido Rangel. $A$ instrumentalidade do processo, cit., n. 33, p. 288 e ss). Apesar de não se dirigir exatamente à hipótese do presente trabalho, vale a crítica feita à busca obsessiva pela segurança, que não deve pautar o posicionamento do julgador.

${ }^{80} \mathrm{Na}$ doutrina italiana, colhe-se a opinião de Vittorio Colesanti, a respeito da "revocazione", instituto que possui certa similitude com a nossa ação rescisória: "Autorevolemente si è detto che i menzionati motivi "rappresentano lo stretto margine che consente l'impugnazione di una sentenza gravemente viziata nella
} 
A finalidade da ação rescisória, consoante os termos da lei, é a de desconstituir (natureza constitutiva negativa) decisão judicial de mérito, transitada em julgado, havendo, se necessário, o rejulgamento da causa em que a decisão foi desconstituída.

Com o costumeiro acerto, o professor Flávio Yarshell enfatiza a relação direta existente entre os valores albergados pela ação rescisória e os escopos do processo, ressaltando a importância do tema, asseverando que, "o tema diz respeito aos escopos do processo, dado que confronta a estabilidade que conduz à pacificação social, de um lado, e a busca de justiça, de outro. Embora não resida aí qualquer novidade - muito pelo contrário - , fato é que com o passar do tempo modifica-se o entendimento do que sejam os casos de invalidade ou injustiça graves a ponto de justificar a rescisão (...)"81.

Portanto, é lícito concluir-se que a ação rescisória visa assegurar o escopo jurídico da jurisdição, entendido este como a atuação da vontade concreta da lei, através da justa composição da lide ${ }^{82}$. Conforme observa o professor Dinamarco, a adjetivação justa demonstra a legítima preocupação ética pelos resultados do processo, em consonância com a proposta instrumentalista, que preconiza uma visão teleológica do processo.

Assim, não se concebe mais uma visão puramente formal do direito, distanciada do valor justiça, em que somente importaria a observância formal aos preceitos jurídicos, sem qualquer preocupação teleológica.

A preocupação de se alcançar o ideal da justiça através do processo está intimamente ligado à idéia de devido processo legal substancial, expressão criada no direito norte-americano, que inclui, dentre outras, as garantias de: “a) elaboração regular e correta da lei, bem como de sua razoabilidade, senso de justiça e enquadramento nas

sua formazione" [Liebman]; ed essi sono il frutto, in pari tempo, di una delicata valutazione d'interessi, espressa dal legislatore, tra le esigenze di una decisione giusta ed il principio della sicurezza dei giudicati". (COLESANTI, Vittorio. Sentenza civile (revocazione della). In: AZARA, Antonio; EULA, Ernesto (Coords.). Novissimo digesto italiano. Torino: Torinese, 1957. p. 1169).

81YARSHELL, Flávio Luiz. Ação rescisória: juízos rescindente e rescisório, cit., p. 15.

${ }^{82}$ DINAMARCO, Cândido Rangel. A instrumentalidade do processo, cit., p. 246 e ss., ressalta: "Compor a lide, ou seja, ditar a disciplina jurídica que concretamente a resolve, é uma tarefa puramente jurídica. (...). Além disso, a adjetivação justa (justa composição) traz em si uma carga de preocupação ética pelos resultados do processo, o que aliás constitui coerente reflexo da proposta do método teleológico no trato do sistema processual." 
preceituações constitucionais (substantive due process of Law, segundo o desdobramento da concepção norte-americana)"83.

Couture já apontou a estreita ligação entre a lei processual e o ideal de justiça, ao asseverar que: "A conclusão direta das idéias que acabam de ser apresentadas é aquela que permite afirmar que a lei processual, tomada em seu conjunto, é uma lei regulamentadora dos preceitos constitucionais que asseguram a justiça"84.

Dessa forma, é lícito se supor que, através do processo, atinja-se o escopo jurídico que dele se espera, sendo que este está intimamente ligado à idéia de justiça das decisões e, sendo assim, deve dotar o instrumento dos meios adequados para que este fim seja atingido e, um desses meios é justamente a ação rescisória, que visa afastar do sistema decisões eivadas de certos vícios (predeterminados pelo próprio sistema, por opção política), que o ordenamento entende serem de tamanha gravidade, a ponto de afastar a coisa julgada (e o valor da segurança jurídica albergado por ela), a fim de privilegiar o valor da justiça.

Corroboram esse entendimento as lições de Pontes de Miranda, segundo as quais, "a função da ação rescisória é evitar que a coisa julgada formal 85 , criada no interesse de estabilidade social, de segurança extrínseca, prepondere diante do interesse da justiça, em certas espécies mais relevantes. Com esse propósito de segurança intrínseca, o legislador seleciona essas espécies, determinando quais os pressupostos da rescindibilidade das decisões cíveis." (g.n.).

Costuma-se dizer, não sem razão, que por meio da ação rescisória há o julgamento de julgamento 86 , sendo, dessa forma, processo sobre outro processo, pois através dela se examina a sentença transitada em julgado. Segundo Pontes de Miranda, o

\footnotetext{
${ }^{83}$ TUCCI, Rogério Lauria; CRUZ E TUCCI, José Rogério. Constituição de 1988 e processo: regramentos e garantias constitucionais do processo. São Paulo: Saraiva, 1989. p. 15.

${ }^{84}$ COUTURE, Eduardo J. Introdução ao estudo do processo civil, trad. Mozart Victor Russomano. Rio de Janeiro: Jose Konfino, 1951. p. 33.

Deve-se fazer uma única ressalva ao pensamento do mestre que, não obstante a lei processual de 1973 ter determinado expressamente que somente se rescindem as decisões de mérito (art. 485), ele continuou entendendo que mesmo as decisões terminativas poderiam ser rescindidas, como na legislação anteriormente vigente.

${ }^{86}$ Neste sentido, PONTES DE MIRANDA, Francisco Cavalcanti. Tratado da ação rescisória das sentenças e de outras decisões, cit., p. 120.
} 
que se pretende com a ação rescisória é "a diminuição do número de casos em que a aplicação não coincide com a incidência da lei" 87 .

Com a ação rescisória, o que se desconstitui é a sentença rescindenda e, via de consequência, os efeitos que ela produz 88 , pois inexistindo o ato, seus efeitos não podem subsistir.

\section{II.2. Conceito de rescisão}

A expressão "rescisão" é ordinariamente conceituada como rompimento, corte ${ }^{89}$. O termo, porém, em certas oportunidades, é conceituado de forma equivocada, dando margem a interpretações imprecisas sobre o instituto. De fato, os próprios dicionários jurídicos nem sempre informam com exatidão o conceito do termo. $\mathrm{O}$ Dicionário Jurídico da Academia Brasileira de Letras não registra o significado processual do termo rescisão 90 , referindo-se somente ao seu conceito no âmbito do direito material. Por outro lado, De Plácido e Silva fornece definição desacertada do instituto, ao associá-lo à idéia de nulidade 91 , que se mostra de todo equivocada.

A fim de uma melhor compreensão do tema, faz-se necessário caracterizar exatamente a hipótese de incidência da rescisão de sentença, especialmente distinguindo-a

\footnotetext{
${ }^{87}$ PONTES DE MIRANDA, Francisco Cavalcanti. Tratado da ação rescisória das sentenças e de outras decisões, cit., p. 595.

88

Estes são os esclarecimentos de Pontes de Miranda a respeito: "Contra a existência e a eficácia da sentença vai a ação rescisória, não porque seu fim seja destruir efeitos, mas sim porque, indo contra a sentença mesma, a destrói e lhe destrói, em conseqüência, os efeitos. (...) a destruição é da sentença e - em conseqüência - da possibilidade de vir a ter efeitos." Tratado da ação rescisória das sentenças e de outras decisões, cit., p. 595.

${ }^{89}$ FERREIRA, Aurélio Buarque de Holanda. Novo Dicionário da Língua Portuguesa. 1. ed. 15. reimpr. Rio de Janeiro: Ed. Nova Fronteira. ${ }^{90} \mathrm{C}$

Consta no referido dicionário: “Rescisão: Dir. Obr. Designação genérica para o interrompimento da relação jurídica contratual, quer por manifestação unilateral em caso de inadimplemento de uma das partes (resolução), quer por consenso das partes (resilição)." Porém, indica o termo "Ação Rescisória", como sendo: "Dir. Porc. Civ. Meio processual destinado a tornar ineficaz (não nula) a sentença de mérito transitada em julgado, desde que ocorra um dos vícios graves expressamente mencionados em lei."

${ }^{91}$ Rescisão vem definida como: "Do latim rescissio, de rescindire (separar, destruir, anular, rescindir), entende-se, vulgarmente, o ato pelo qual se desfaz ou se desmancha alguma coisa para que não cumpra seus objetivos ou suas finalidades. Juridicamente, rescisão é a anulação ou a retirada dos efeitos jurídicos do ato, da convenção ou da sentença. A rigor, a rescisão é a anulação por decisão judicial, em virtude do que o que é rescindido perde sua eficácia jurídica, pois que se mostra inexistente."
} 
em relação aos termos nula, nulidade, inexistência, revogação e revisão, relacionados à sentença.

A confusão se deve em razão de outrora, a lei processual vigente com a promulgação do Código de Processo Civil de 1939, no título III, denominado "Da ação rescisória", ter mencionado, no artigo 798, de forma equivocada e atécnica, que "será nula a sentença" passando, então, a discorrer sobre as hipóteses de rescisão de sentença. Tal desacerto causou certo anacronismo na doutrina da época, havendo muitos autores que chegaram a se referir à hipótese de rescisão, como sendo equivalente à nulidade de sentença 92 , utilizando-se de conceitos equivocados.

A falta de clareza no emprego da designação legal foi determinada por razões ligadas a fatores históricos, pois, segundo a terminologia romana, o termo "nulla" possuía o sentido de inexistente e, ao tempo das Ordenações (influenciados pelo sistema romano), para se referir às sentenças existentes, mas inválidas, empregou-se o termo "nenhuma", o qual, na realidade, correspondia à expressão romana "nulla". Assim, quando se passou a utilizar a expressão "rescisão" (ao invés das designações anteriormente utilizadas - porém equivocadas - "decretação da nulidade" ou "declaração de inexistência"), o legislador ainda se manteve vinculado ao obsoleto "nula"93, anteriormente empregado de forma incorreta.

A imprecisão terminológica trouxe consequências à doutrina, que asseverava que as sentenças rescindíveis "não passavam em julgado" (ainda vinculando a noção de rescindibilidade com a de nulidade ou de inexistência), bem como nos ordenamentos da época, havendo algumas que mencionavam que as sentenças rescindíveis poderiam ser impugnadas a qualquer tempo 94 , em razão da confusão que faziam entre sentenças rescindíveis e sentenças inexistentes ou nulas.

\footnotetext{
${ }^{92}$ Por exemplo, Luis Eulálio Vidigal conceitua a ação rescisória como: "a ação pela qual se pede a declaração da nulidade da sentença”, in VIDIGAL, Luis Eulálio de Bueno. Ação rescisória dos julgados. São Paulo: Saraiva, 1948. p. 16, g.n. Ainda, Jorge Americano define a ação rescisória como "a acção pela qual se pede a decretação da nullidade ou illegalidade de uma sentença que extrinsecamente passou em julgado (...), in Da acção rescisoria dos julgados no direito brasileiro, cit., p. 9 e ss.

${ }^{93}$ De acordo com Pontes de Miranda, Tratado da ação rescisória das sentenças e de outras decisões, cit., p. 608 e ss.

${ }^{94}$ v.g. Ordenações Manuelinas, 3.60.
} 
Com efeito, sentença inexistente é aquela "desprovida de elementos essenciais" ou "proferida em 'processo' a que falte pressuposto de existência"95. A sentença inexistente pode ser assim declarada por qualquer juiz, em qualquer situação em que se deparar com uma sentença nesses termos proferida.

A sentença nula é a que não tenha observado alguma regra de direito material ou substancial, v.g., que tenha julgado extra petita. Com o trânsito em julgado a nulidade é sanada, podendo a sentença somente ser desconstituída por ação rescisória 96. Pontes de Miranda tem entendimento contrário, nos seguintes termos: "A sentença nula é sentença, porém desconstituível por invalidade, sem se precisar de propositura de 'ação', da querela de nulidade. O juiz que encontra, sob sua cognição, sentença nula pode decretar-lhe a nulidade." 97 . Segundo seu entendimento, a sentença nula não é capaz de surtir efeitos, não havendo, assim, necessidade de propositura de ação rescisória para sua desconstituição, podendo a nulidade da sentença ser reconhecida a qualquer tempo, sem maiores formalidades, por decisão declaratória 98 .

Em nosso sistema processual não existe a previsão de sentença anulável ${ }^{99}$. A revogação, por sua vez, possui o sentido de retirar a voz ${ }^{100}$, tal expressão era utilizada quando as decisões estavam à mercê do príncipe ${ }^{101}$. E, finalmente, o vocábulo revisão, em nosso ordenamento jurídico, possui sentido diverso da maioria dos demais, pois é utilizado para impugnar as decisões proferidas nas relações de trato continuado, tendo como pressuposto, a existência de fato novo 102 .

Com bem esclarece Pontes de Miranda, rescindir é cortar, cindir e, portanto, a ação rescisória "é para rescindir, e não para se revogar ou reformar a sentença, nem, a

\footnotetext{
${ }^{95}$ Conforme Barbosa Moreira, in Comentários ao Código de Processo Civil, cit., p. 107.

${ }^{96}$ Comentários ao Código de Processo Civil, cit.

${ }^{97}$ PONTES DE MIRANDA, Francisco Cavalcanti. Tratado da ação rescisória das sentenças e de outras decisões, cit., p. 447 e ss.

${ }^{98}$ Porém, em momento posterior, o autor reconhece a existência de nulidades que resistiriam à res judicata, como sendo as que "se falta algum requisito de validade" (p. 452 e ss). Nota-se que o autor se refere, na realidade, às sentenças "inexistentes", sugerindo como remédio para tais sentenças, a ação de nulidade.

${ }^{99}$ Nesse sentido, PONTES DE MIRANDA, Francisco Cavalcanti. Tratado da ação rescisória das sentenças e de outras decisões, cit., p. 451.

${ }^{100}$ Conforme PONTES DE MIRANDA, Francisco Cavalcanti. Tratado da ação rescisória das sentenças e de outras decisões, cit., p. 102.

${ }^{101}$ YARSHELL, Flávio Luiz. Ação rescisória: juízos rescindente e rescisório, cit., p. 24.

${ }^{102}$ Ação rescisória: juízos rescindente e rescisório, cit., p. 24.
} 
fortiori, para se "declarar" inexistência"103 e, assim sendo, só se rescinde o que existe, é válido e eficaz.

Cabe reforçar que a decisão rescindente não possui efeito declaratório, mas constitutivo negativo, assim, quando se trata de ação rescisória, não se pode falar em "declaração" de nulidade ou de ineficácia, pois, consoante esclarecido, não se cuida nem de declaração, nem de nulidade, e nem ainda, de ineficácia do ato. A ação rescisória desconstitui o próprio ato judicial que é a sentença e não apenas os seus efeitos, pois, como é notório, pode haver ato válido, mas ineficaz (que não é a hipótese), pois o próprio ato é que se desfaz, ou seja, a própria sentença (ou decisão transitada em julgado) é que deixa de existir no mundo jurídico.

São bem esclarecedoras as palavras de Pontes de Miranda a respeito da exata caracterização da sentença rescindível, no que tange à distinção com o ato anulável: "Ao desconstituir-se a sentença rescindivel, destroem-se efeitos produzidos e destroem-se ex tunc. Tudo aproxima da anulabilidade a rescisão, exceto o que está no cerne mesmo da diferença conceptual: a sentença rescindível é $e$ vale; o ato jurídico anulável é $e$ não vale" 104 .

\section{II.3. Juízo rescindente e juízo rescisório}

Como é notório, na ação rescisória é possível que ocorram duas ordens de julgamento 105 , o primeiro, antecedente lógico e necessário do segundo, denominado de juízo rescindente (iudicium rescindens), através do qual se opera a cassação ou desconstituição do ato impugnado (sentença de mérito transitada em julgado, consoante os termos do caput do artigo 485 do Código de Processo Civil), e o segundo, que nem sempre será necessário, designado juízo rescisório (iudicium recissorium), por meio do qual se realiza novo julgamento da matéria originária (a qual foi decidida pela decisão cassada no juízo rescindente).

${ }^{103}$ PONTES DE MIRANDA, Francisco Cavalcanti. Tratado da ação rescisória das sentenças e de outras decisões, cit., p. 103.

${ }^{104}$ Tratado da ação rescisória das sentenças e de outras decisões, cit., p. 451.

${ }^{105}$ O que não exclui a verificação do preenchimento das condições da ação e dos pressupostos processuais (pressupostos de constituição e desenvolvimento válido e regular do processo), num juízo de admissibilidade, preliminar ao mérito. 
A decisão que cassa a sentença de mérito anterior (juízo rescindente) possui natureza jurídica constitutiva negativa, porém, seus efeitos não se operam ex nunc como, via de regra, ocorre com as sentenças constitutivas 106 , na medida em que as partes devem ser restituídas ao estado anterior ${ }^{107}$, podendo-se fazer um paralelo com a regra do artigo 182 do Código Civil 108 (não obstante não se cuidar de anulação propriamente dita, como já visto, no caso de rescisão). A doutrina aponta, ainda, como um dos principais problemas nessa hipótese, situações fáticas consolidadas antes da propositura da ação rescisória e, que foram praticadas levando-se em consideração a sentença rescindenda. Por exemplo, no caso de rescisão da sentença que declarou o divórcio, quando qualquer das partes já tiver contraído segundo matrimônio, inclusive com a existência de filhos. Nesse contexto, Barbosa Moreira afirma que não se pode estabelecer regras apriorísticas, impondo-se a análise de cada caso concreto, muitas vezes à luz do direito material ${ }^{109}$.

A situação nos parece muito semelhante àquelas referentes à declaração de inconstitucionalidade de lei ou ato normativo através do controle concentrado ou da arguição de preceito fundamental, nos quais as respectivas leis preveem expressamente a denominada modulação dos efeitos da sentença 110 , segundo a qual, em razão dos mesmos motivos, ou seja, da existência de situações fáticas já consolidadas sob a égide da lei ou ato declarados inconstitucionais, permite-se ao Supremo Tribunal Federal, em tais casos, "restringir os efeitos daquela declaração ou decidir que ela só tenha eficácia a partir de seu trânsito em julgado ou de outro momento que venha a ser fixado".

Por outro lado, a decisão proferida no juízo rescisório terá a natureza jurídica estabelecida de acordo com o pedido formulado no processo originário. Não é de rigor que o autor da ação rescisória faça pedido relativo ao rejulgamento da causa (ou ao juízo rescisório), pois este será apreciado de acordo com o quanto existente na ação

\footnotetext{
${ }^{106}$ DINAMARCO, Cândido Rangel. Instituições de direito processual civil, cit., v. 3, p. 261.

${ }^{107}$ Ver a propósito, Flávio Yarshell que, citando Jorge Americano, assevera: “[...]. Não há dúvida de que conseqüência da procedência do pedido quanto ao juízo rescindente "é a obrigação de reequilibrar a situação jurídica desequilibrada pela primeira sentença, colocando as partes no estado em que por ela se deveriam colocar" - para lembrar as palavras de Jorge Americano. Dessa forma, - como observou o mesmo autor -, devem ser restituídos os frutos e rendimentos recebidos indevidamente, o possuidor deve responder pelo perecimento ou deterioração da coisa e, não lhe cabem acessões ou benfeitorias, salvo as necessárias [...].” In Ação rescisória: juízos rescindente e rescisório, cit., p. 350, nota 9.

Nesse sentido, DINAMARCO, Cândido Rangel. Instituições de direito processual civil, cit., v. 3, p. 261 e, especificamente para a ação rescisória, BARBOSA MOREIRA, José Carlos. Comentários ao Código de Processo Civil, cit., p. 210.

${ }^{109}$ BARBOSA MOREIRA, José Carlos. Comentários ao Código de Processo Civil, cit., p. 210.

${ }^{110}$ Art. 27, da Lei n ${ }^{\circ} 9868 / 99$ e art. 11, da Lei n ${ }^{\circ} 9882 / 99$.
} 
primitiva (que teve sua sentença cassada), dentro do âmbito da rescisão operada, ou seja, se havia uma cumulação de pedidos e apenas em relação a um houve a rescisão, somente este será reapreciado por ocasião do juízo rescisório. Trata-se, na realidade, de pedido implícito 111 , pois sendo necessário o juízo rescisório, operando-se o juízo rescindente, não subsiste decisão alguma, havendo um vazio e, não sendo possível a existência de processo sem decisão final, faz-se necessário (se for a hipótese), a prolação de nova decisão, de acordo com o pedido já constante no processo originário 112 .

Segundo bem observado por Flávio Yarshell, tanto o juízo rescindente, assim entendido como a cassação ou desconstituição do ato impugnado, como o juízo rescisório, concebido como o novo julgamento da matéria, podem estar presentes não só no âmbito da ação rescisória, como também nos mais diversos meios de impugnação ${ }^{113}$, advertindo que, no direito brasileiro não existe recurso totalmente desprovido da função rescindente. Tal se dá, por exemplo, no caso apelação, em que, apreciando o mesmo o tribunal, quer reforme a decisão de primeiro grau, quer a "mantenha”, por força do artigo 512 do Código de Processo Civil, operar-se-á a substituição da sentença pelo julgamento proferido pelo tribunal, o que equivale dizer, a decisão impugnada será desconstituída e substituída pelo acórdão do tribunal, que terá proferido novo julgamento sobre a matéria impugnada.

\section{II.4. Os elementos da ação rescisória}

Nesse tópico examinaremos os principais elementos da ação rescisória e as principais controvérsias que podem suscitar cada um desses elementos analisados.

\footnotetext{
${ }^{111}$ Neste sentido, PONTES DE MIRANDA, Francisco Cavalcanti. Tratado da ação rescisória das sentenças $e$ de outras decisões, cit., p. 81 e ss.; YARSHELL, Flávio Luiz. Ação rescisória: juízos rescindente e rescisório, cit., p. 356. Em sentido contrário, COSTA, Moacyr Lobo da. Cumulação de juízos na ação rescisória, cit., p. 21. Entendendo que não havendo pedido explícito, será o caso de indeferimento da inicial, nos moldes do caput do art. 284 e seu parágrafo único, do CPC, BARBOSA MOREIRA, José Carlos. Comentários ao Código de Processo Civil, cit., p. 177 e ss.

${ }^{112}$ E sempre no âmbito da decisão rescindida.

${ }^{113}$ Ver a respeito YARSHELL, Flávio. Ação rescisória: juízos rescindente e rescisório, cit., especialmente n. 3, p. 27 e ss.
} 
Como se sabe, a competência para julgar a ação rescisória é dos tribunais, mais precisamente, dos órgãos colegiados 114 , para rescindir suas próprias decisões de mérito, e dos tribunais que seriam competentes para conhecer do eventual recurso cabível contra a sentença de mérito de primeira instância. Nesse particular, incumbe fazer um primeiro esclarecimento no que tange aos julgamentos proferidos pelos tribunais superiores, os quais, ao julgarem recurso especial e recurso extraordinário, adotam terminologia inadequada, fazendo constar na conclusão o não conhecimento dos recursos nos verdadeiros casos de improcedência ${ }^{115}$. Ora, como é curial, se a decisão não for de mérito (no caso de não conhecimento do recurso), não caberá ação rescisória contra aquela decisão, mas, eventualmente contra a decisão anterior que tiver julgado o mérito, o que afetará significativamente a competência para julgamento da ação rescisória. Nessas hipóteses de imprecisão terminológica, fica relegada à parte a verificação e interpretação da decisão para constatar se houve ou não apreciação do mérito, a fim de estabelecer o tribunal competente para a ação rescisória. É o que se infere da redação da Súmula 249 do Supremo Tribunal Federal 116 .

Sendo ônus da parte a identificação da decisão a ser rescindida, outra questão relevante acerca da competência surge no que concerne à incorreta identificação da decisão a ser rescindida e, por consequência, do tribunal competente para a ação rescisória. Nesses casos, parcela da mais balizada doutrina assevera que o erro não pode ser corrigido de ofício pelo tribunal ${ }^{117}$, ou sequer pode ser corrigido, levando à extinção da ação rescisória por carência de ação, por falta de interesse-adequação ao autor da ação rescisória que teria indicado incorretamente o acórdão que pretende rescindir, faltando-lhe utilidade

\footnotetext{
${ }^{114}$ Significa dizer que o relator não poderá julgar o mérito da ação rescisória, mas somente o órgão colegiado competente para tanto, de acordo com a decisão a ser rescindida e as normas internas de cada tribunal.

${ }^{115} \mathrm{O}$ problema já fora apontado desde cedo por Barbosa Moreira, inclusive em relação às repercussões no âmbito da ação rescisória: “d) Tal diferença, por sua vez, repercute na questão do prazo para a propositura da eventual ação rescisória: se o têrmo inicial se determina pelo momento de formação da res iudicata, variando êste, necessariamente varia aquêle. e) Ainda no tocante à hipótese de rescisão do julgado, a influência da distinção faz sentir-se noutro aspecto relevante: o da competência para o processo da rescisória [...]". (BARBOSA MOREIRA, José Carlos. O juízo de admissibilidade no sistema dos recursos civis. 1968. Tese (Livre-Docência) - Faculdade de Direito da Universidade do Estado da Guanabara. Rio de Janeiro, 1968. n. 21, p. 35).

${ }^{116}$ Diz a referida Súmula: "É competente o Supremo Tribunal Federal para a ação rescisória, quando, embora não tendo conhecido do recurso extraordinário, ou havendo negado provimento ao agravo, tiver apreciado a questão federal controvertida". Barbosa Moreira acusa tal expediente de "berrante artificialismo", utilizado como subterfúgio para correção da inexatidão técnica dos tribunais superiores ( $O$ juízo de admissibilidade no sistema dos recursos civis, cit., n. 24, p. 30).

${ }^{117}$ Neste sentido, Barbosa Moreira, in Comentários ao Código de Processo Civil, cit., n. 121, p. 202 e ss., mas possibilitando ao interessado emendar a inicial, nos termos do caput do art. 284 do CPC.
} 
na rescisão pretendida, pois o verdadeiro acórdão que teria apreciado por último a questão meritória, permaneceria incólume ${ }^{118}$. No entanto, parece-nos que se cuida de erro escusável (especialmente nos casos acima tratados), devendo ser solucionado à luz do disposto no parágrafo segundo do artigo 113 do Código de Processo Civil, remetendo-se os autos ao juízo competente 119

Com relação à legitimação para figurar como parte na ação rescisória, devese levar em conta os limites subjetivos da coisa julgada que se pretende rescindir. Assim, a princípio, serão partes legitimadas para figurar como autor e réu na ação rescisória quem era parte na ação originária no momento em que a decisão rescindenda foi proferida 120 , pois estes é que foram atingidos pela coisa julgada que se formou. Nesse particular, cumpre esclarecer que, tendo havido cumulação subjetiva e objetiva na ação em que foi proferida a decisão rescindenda, deve-se, igualmente, observar os limites da coisa julgada em relação a cada um, para se verificar a legitimidade para a ação rescisória ${ }^{121}$, ou seja, se houve vários capítulos na sentença rescindenda autônomos entre si (decorrentes da cumulação objetiva) e, se apenas uma parte da sentença se pretende rescindir, somente as partes atingidas por aquele capítulo é que devem estar na relação jurídica que se formará na ação rescisória. Da mesma forma, se não tiver sido o caso de litisconsórcio unitário na ação originária, podendo-se cindir a decisão rescindenda em relação a cada uma das partes, também não será de rigor que todas figurem como parte na ação rescisória.

Além das partes constantes da relação originária, ou seja, em que foi proferida a sentença rescindenda, o artigo 487 do Código de Processo Civil enumera como legitimados o sucessor da parte (a título universal ou singular), o terceiro juridicamente interessado e o Ministério Público (se não foi ouvido no processo em que lhe era

\footnotetext{
${ }^{118}$ É a posição defendida por Cândido Dinamarco, in Ação rescisória, incompetência e carência de ação. Revista de Processo, ano 26, n. 104, p. 11-19, out./dez. 2001.

${ }^{119}$ No mesmo sentido, YARSHELL, Flávio Luiz. Ação rescisória: juízos rescindente e rescisório, cit., esp. p. 276 e ss.

${ }^{120}$ Conforme Barbosa Moreira, "Quem pretende rescindir a sentença deve ter sido parte no momento em que ela foi proferida, não importando se figurou na relação processual anterior $a b$ initio, ou se nela só ingressou no curso do feito. Não se legitima à rescisória, como "parte", que já não o era ao tempo da sentença, por haver-se desligado antes, voluntariamente ou não, da relação processual." (Comentários ao Código de Processo Civil, cit., n. 98, p. 168). Em sentido contrário, NERY JUNIOR, Nelson; NERY, Rosa Maria de Andrade. Código de processo civil comentado e legislação processual civil extravagante em vigor: atualizado até 15.03.2002. São Paulo: Ed. Revista dos Tribunais, 2002, comentário n. 1 e 2, ao art. 487, CPC, p. 806.

${ }^{121}$ Cabe lembrar que a coisa julgada atinge somente a parte dispositiva da sentença e, nessa medida, ela é que deverá balizar a verificação da legitimidade (bem como do interesse jurídico) para a ação rescisória.
} 
obrigatória a intervenção e quando a sentença é o efeito de colusão das partes, a fim de fraudar a lei).

A respeito, impende ressaltar que a lei não faz distinção se a sucessão da parte se deu inter vivos ou causa mortis. Dessa forma, tendo havido a sucessão no plano do direito material, ainda que posteriormente ao encerramento do processo originário, $\mathrm{o}$ sucessor será o legitimado para a ação rescisória 122 .

Quanto ao terceiro juridicamente interessado, não se vislumbra a possibilidade de este valer-se da ação rescisória, não obstante os termos da lei, na medida em que, na qualidade de terceiro, não será atingido pela coisa julgada que se formou no processo originário e, caso tenha a esfera de seus direitos indevidamente atingida pela sentença formada na relação processual entre as partes (efeitos da sentença), a imutabilidade desses efeitos não o alcançarão 123 , justamente por ser terceiro estranho à relação jurídica processual que anteriormente se formara ${ }^{124}$; assim, poderá opor-se àquela decisão através dos meios ordinários para tanto 125 .

Neste sentido é o entendimento de Giovanni Alessio, que ressalva, com propriedade:

\begin{abstract}
"Inoltre, benchè alcune legislazioni, come La Sarda, l'abbiano disconosciuto, la nostra vigente, pone quale gravame contro la sentenza, l'opposizione del terzo. Qui l'errore è più grave. Chi non prese parte in giudizio è tutelato dalla exceptiones inter alios [...]. La sentenza fa sempre stato fra le parti contendenti, il terzo non l'impugna, nè il giudizio si rinnova pel suo intervento; egli si limita a chiedere, che si dichiari preventivamente, che quella sentenza, quel giudicato, rispetto a lui, è res inter alios"126
\end{abstract}

\footnotetext{
${ }^{122}$ É de se pensar, por exemplo, na hipótese de determinada demanda sobre a propriedade de certo bem e, após o encerramento da demanda, a parte vencedora aliena o referido bem a terceiro. Sendo o caso de ação rescisória, o vencido na demanda originária deverá propor a ação em face do adquirente do bem, em razão do disposto no artigo 487, I, do CPC.

${ }^{123}$ Ver a propósito, LIEBMAN, Enrico Tullio. Eficácia e autoridade da sentença e outros escritos sobre a coisa julgada, cit.

${ }^{24}$ Caso esse terceiro tenha intervindo na ação originária, obviamente deixou de ser terceiro passando a ser parte, não se lhe aplicando a hipótese em comento (art. 487, II, do CPC).

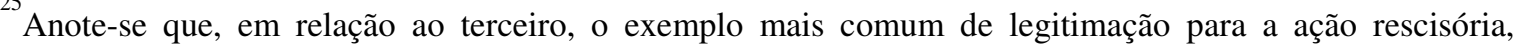
conferido pela doutrina e pela jurisprudência, é a hipótese de sucessão que se concretiza após a sentença rescindenda. Contudo, referida hipótese está abrangida no inciso I do art. 487 do CPC e não no II.

${ }^{126}$ ALESSIO, Giovanni. La revocazione delle sentenze civili. Napoli: Nicola Jovene, 1888. p. 5.
} 
Situação peculiar diz respeito à necessidade (ou não) de todos os vencidos na demanda originária figurarem no polo ativo da ação rescisória, na hipótese de tratar-se de litisconsórcio unitário, ou seja, em que não é possível cindir o objeto da demanda, devendo todos necessariamente figurar como parte. Caso um ou alguns não tenham interesse na propositura da ação rescisória (em que necessariamente deveriam figurar, $v . g$., anulação de determinado contrato em que as obrigações são incindíveis), qual solução a ser adotada, em razão do princípio de que não se pode compelir ninguém a demandar? Flávio Yarshell é da opinião de que, não figurando todos os vencidos na demanda originária no polo ativo da ação rescisória, não se pode simplesmente transpô-los para o polo passivo, figurando como réus na ação rescisória, sendo a hipótese de ser decretada a carência de ação por ilegitimidade ativa ad causam 127 .

Porém, semelhante entendimento não nos parece o mais acertado, pois, como lembra o próprio mestre, tal circunstância acabaria por limitar consideravelmente o acesso da parte à Justiça, que se veria de mãos atadas diante de uma situação que, no seu entender, seria tão grave a ponto de ensejar a rescisão da sentença transitada em julgado, incutindo-lhe um enorme sentimento de injustiça (ainda mais quando a solução foge ao seu controle, pois dependeria do desejo de terceiros - que figuraram como partes no processo originário - aceitarem propor a demanda rescisória conjuntamente a ele).

Demais disso, justamente em face da gravidade dos vícios eleitos no artigo 485 do Código de Processo Civil é que o ordenamento, por opção legislativa, concebeu o meio típico da ação rescisória, pois a permanência de vícios que reputa de gravidade suficiente, que resistem à preclusão máxima que se opera com a coisa julgada e autorizam a revisão da coisa julgada que se formou no processo originário, não interessa nem às partes, nem à sociedade, pois, de modo contrário, acarretaria o descrédito da sociedade civil no Judiciário, o qual, ao invés de servir de instrumento de pacificação social, acabaria por instaurar o sentimento de injustiça na sociedade 128 . Destarte, a solução que se nos afigura mais correta seria a de incluir as demais partes (litisconsortes unitários e necessários), que não quiseram figurar no polo ativo da demanda, como réus na ação rescisória.

\footnotetext{
${ }^{127}$ YARSHELL, Flávio Luiz. Ação rescisória: juízos rescindente e rescisório, cit., n. 45, p. 140 e ss.

${ }^{128}$ De fato, pela leitura dos incisos do art. 485 do CPC percebe-se quão perniciosos à sociedade são os vícios nele elencados; assim, suprimir da parte que vislumbra tais vícios, de natureza tão graves, a possibilidade de manejar a ação rescisória, tão-somente porque os demais legitimados necessários não pretendem ingressar com a demanda rescisória, parece-nos um desprestígio ao sistema de solução das controvérsias, posto pelo Estado no interesse da sociedade.
} 
Por tratar-se de ação, a petição inicial da ação rescisória deverá observar todos os requisitos do artigo 282 do Código de Processo Civil, aplicáveis ao caso, conforme determina o caput do artigo 488 do Código de Processo Civil e, não obstante os termos do inciso I do mencionado artigo, não é de rigor, embora desejável, a cumulação do pedido do juízo rescindendo com o juízo rescisório, consoante esclarecido no tópico precedente.

Nesses termos, cumpre ao autor da ação rescisória descrever com acuidade os fatos e os fundamentos jurídicos que embasam a sua pretensão, não sendo possível ao tribunal, caso vislumbre outro vício na decisão rescindenda, atuar de ofício e rescindir a decisão por este outro fundamento, uma vez que vigora o princípio da demanda também para as ações rescisórias. Da mesma forma, será permitido ao tribunal rescindir a decisão original por violação a outra norma que não a apontada na inicial (por exemplo, caso haja equívoco na indicação do número do artigo tido por violado, desde que resta claro da causa de pedir a norma que se entende violada, não há problemas; o que não é possível é que, caso haja várias infrações normativas, o autor aponte apenas uma delas como causa de pedir e o tribunal, de ofício, conheça de violação a outra norma). Ainda, é irrelevante o eventual equívoco na indicação dos incisos do artigo 485 do Código de Processo Civil, pois aplica-se, no caso, o princípio iura novit curia ${ }^{129}$.

Quanto ao depósito prévio determinado no inciso II do artigo 488 do Código de Processo Civil, a título de multa no caso de a ação rescisória ser declarada, por unanimidade de votos, improcedente ou inadmissível, é entendimento consolidado na doutrina que tal importância possui intuito de coibir abusos no manejo do meio excepcional que constitui a ação rescisória, fazendo jus à isenção da referida taxa, aqueles que gozem do benefício da assistência judiciária gratuita. A ausência do depósito, quando devido, abre ensejo ao indeferimento da petição inicial, nos termos do inciso II, do artigo 490 do Código de Processo Civil. Quando se tratar de pluralidade de pessoas, tanto no polo ativo quanto no polo passivo da demanda (litisconsórcio), o percentual, por óbvio, não deverá se alterar, ou seja, deverá ser dividido em partes iguais entre os autores e, no caso de improcedência, igualmente será dividido entre os réus (ou, proporcionalmente, na medida de seus interesses, significa dizer, se o benefício pleiteado puder ser identificado e

\footnotetext{
${ }^{129}$ Ver a respeito, PONTES DE MIRANDA, Francisco Cavalcanti. Tratado da ação rescisória das sentenças $e$ de outras decisões, cit., p. 486; BARBOSA MOREIRA, José Carlos. Comentários ao Código de Processo Civil, cit., especialmente n.78, p. 132 e n. 124, p. 205 e YARSHELL, Flávio Luiz. Ação rescisória: juízos rescindente e rescisório, cit., n. 48, p. 150 e ss.
} 
dividido entre as partes, o autor que, por exemplo, pleitear $20 \%$ do total pretendido, deverá ficar responsável por $20 \%$ do valor do depósito devido) ${ }^{130}$.

Além da hipótese supra (falta de depósito prévio da multa), o relator poderá indeferir a inicial nos casos previstos no artigo 295 do Código de Processo Civil, a teor do quanto prescrito no artigo 490, I, do Código de Processo Civil, mas não sem antes dar oportunidade para o autor emendar a inicial, conforme previsto no caput do artigo 284 do mesmo Codex.

Na hipótese de indeferimento da inicial pelo relator, não dispondo o Código de recurso específico para tanto, deverá ser observado o regimento interno de cada tribunal para se verificar a medida cabível, que será, na maioria dos casos, o recurso de agravo.

Impende ressaltar que, tendo em vista que o objeto da ação rescisória é classificado como direito indisponível, consoante anteriormente esclarecido ${ }^{131}$, a doutrina mais autorizada entende não se operarem os efeitos da revelia na ação rescisória, ainda que o réu não ofereça defesa, incidindo a ressalva constante no inciso II, do artigo 320, do Código de Processo Civil ${ }^{132}$.

A doutrina, ainda, se inclina pela necessidade de intervenção do Ministério Público nas ações rescisórias como custos legis, quanto este não for parte na demanda, em razão da existência de interesse público, derivado da própria natureza da ação rescisória, na qual se discute decisão de mérito transitada em julgado (e que ataca, portanto, a coisa julgada anteriormente formada) ${ }^{133}$.

\footnotetext{
${ }^{130}$ Nem poderia ser de outra forma, pois, se imaginássemos uma demanda multitudinária, em que houvesse vinte réus e só um autor, não seria lícito se exigir que esse autor depositasse vinte vezes a quantia devida a título de multa (ou seja, 100\% do valor da causa), o que acabaria por inviabilizar o seu direito de acesso ao judiciário. O mesmo raciocínio pode ser feito no sentido inverso, ou seja, caso houvesse vinte autores e só um réu, a eventual improcedência da demanda, por votação unânime, acabaria por propiciar um enriquecimento sem causa do réu, o que é vedado pelo nosso ordenamento jurídico (artigo 884 do Código Civil).

${ }^{131}$ Vide supra tópico n. III.4, parte primeira.

${ }^{132}$ Conforme BARBOSA MOREIRA, José Carlos. Comentários ao Código de Processo Civil, cit., n. 114, p. 194; YARSHELL, Flávio Luiz. Ação rescisória: juízos rescindente e rescisório, cit., n. 48, p. 152 e TAALMINI, Eduardo. Coisa julgada e sua revisão, cit., p. 67 e ss.

${ }^{133}$ Neste sentido, Barbosa Moreira, Comentários ao Código de Processo Civil, cit., n. 120, p. 199 e YARSHELL, Flávio Luiz. Ação rescisória: juízos rescindente e rescisório, cit., n. 85, p. 275.
} 
Finalmente, é tranquilo o entendimento de que o prazo extintivo de dois anos à que se refere o caput do artigo 495 do Código de Processo Civil é decadencial ${ }^{134}$, não se interrompendo nem suspendendo e conta-se do dia em que a sentença rescindenda transitou em julgado 135 .

${ }^{134}$ Ver a respeito, BARBOSA MOREIRA, José Carlos. Comentários ao Código de Processo Civil, cit., n. 130, p. 218 e ss; TALAMINI, Eduardo. Coisa julgada e sua revisão, cit., n. 3.5, p. 191.

${ }^{135}$ Nesse aspecto, doutrina e jurisprudência são divergentes quanto ao termo a quo para contagem do prazo decadencial. A doutrina majoritária entende que o prazo para ação rescisória de cada capítulo da sentença conta-se separadamente, ou seja, se cada capítulo autônomo transitou em julgado em datas diferentes, o prazo inicial para a ação rescisória contar-se-á do trânsito em julgado de cada capítulo (neste sentido: YARSHELL, Luiz Flávio. Ação rescisória: juízos rescindente e rescisório, cit., n. 41, p. 132 e ss e TALAMINI, Eduardo. Coisa julgada e sua revisão, cit., n. 3.5, p. 192 e ss.). Contudo, a jurisprudência tem entendido de forma diversa, ou seja, pela contagem do prazo decadencial a partir da última decisão de mérito proferida no processo, tendo sido editada a Súmula 401 do Superior Tribunal de Justiça, que possui a seguinte redação: "O prazo decadencial da ação rescisória só se inicia quando não for cabível qualquer recurso do último pronunciamento judicial." 
C - PARTE TERCEIRA 


\section{DECISÕES SUJEITAS À AÇÃO RESCISÓRIA}

O caput do artigo 485 do Código de Processo Civil determina que a sentença de mérito transitada em julgado é que pode ser rescindida. Porém, deve-se entender que a sentença aí está colocada por decisão, atribuindo-se um sentido mais amplo ao vocábulo. Por sentença de mérito, deve-se entender aquela que decide a relação de direito material posta em juízo ${ }^{136}$. O critério utilizado, destarte, para se saber se a decisão pode ou não ser impugnada pela via rescisória, é o da aptidão a formar a coisa julgada137 138. A questão, portanto, está intrinsecamente ligada aos limites objetivos da coisa julgada, anteriormente tratada em tópico específico 139.

Para a viabilidade da ação rescisória, deve-se verificar a natureza da decisão, não importando que se tenha utilizado terminologia incorreta, como comumente ocorre nos tribunais superiores que, ao negarem provimento aos recursos, consignam não ter conhecido do mesmo. Ressalte-se que não é necessário que a parte interessada tenha esgotado todos os meios de impugnação da decisão que se pretende rescindir, nem se exige o prequestionamento da matéria.

Para se identificar qual a decisão a ser rescindida, basta verificar a última delas que analisou a matéria objeto da ação rescisória. Assim, se uma decisão possui vários capítulos, pode ocorrer que uma parte desses capítulos tenha sido analisada por uma decisão de instância inferior e outro por decisão de instância superior (quer por não ter conhecido parcialmente do recurso, quer por ter sido parcialmente impugnada a matéria).

Deve-se rescindir a última decisão de mérito sobre a matéria 140.

\footnotetext{
${ }^{136}$ Barbosa Moreira ressalta que: "Em todo caso, os dizeres do art. 269 servem de guia na interpretação do art. 485, caput, onde reaparece a expressão "de mérito". Ao nosso ver, num e noutro texto figura ela em idêntica acepção, sempre a designar as sentenças sobre as quais se possa formar a res iudicata material." (Comentários ao Código de Processo Civil, cit., n. 69, p. 110).

${ }^{137}$ Sobre o tema, remete-se o leitor ao Capítulo III, da parte 1, do presente trabalho.

${ }^{138}$ Assim sendo, só se poderá ingressar com ação rescisória levando-se em consideração a parte dispositiva da decisão. Caso a parte maneje ação rescisória unicamente para alterar os fundamentos da decisão, nos dizeres de Flávio Yarshell, faltará à parte interesse processual para tanto (YARSHELL, Flávio Luiz. Ação rescisória: juízos rescindente e rescisório, cit., n. 39, p. 128).

${ }^{139}$ Vide tópico III.5, da parte 1, do presente estudo.

${ }^{140}$ Note-se que o acórdão que "confirma" a decisão impugnada, a substitui, por força da regra do art. 512 do CPC, não mais subsistindo a decisão recorrida na parte "confirmada", portanto, é dessa última decisão que se deve pedir a rescisão. Nas palavras do mestre Pontes de Miranda, "O que é rescindível á a única sentença, ou, se houve recurso, o último acórdão que conheceu da matéria cujo reexame se pede."
} 
Nesse aspecto, cumpre esclarecer que o vício apontado na ação rescisória não precisa ser atinente ao mérito, somente a decisão a ser rescindida precisa ser de mérito 141 , igualmente, não é necessário que o vício resida na sentença, podendo este ter sido praticado no curso processo, maculando todo o restante.

O outro requisito necessário à ação rescisória, é que a sentença tenha transitado em julgado. Nesse aspecto, impende ressaltar que, não importa por que forma o trânsito em julgado ocorreu (ou seja, se houve o esgotamento de todas as vias recursais, transcurso de prazo in albis, aquiescência com a sentença etc.), incumbe somente verificar se esta efetivamente ocorreu.

Consigne-se, finalmente, ser possível a ação rescisória interposta em outra ação rescisória, desde que presentes todos os requisitos.

A seguir, analisaremos as possíveis decisões que podem (ou não) dar ensejo à ação rescisória.

(PONTES DE MIRANDA, Francisco Cavalcanti. Tratado da ação rescisória das sentenças e de outras decisões, cit., p. 351).

${ }^{141}$ Neste sentido: BARBOSA MOREIRA, José Carlos. Comentários ao Código de Processo Civil, cit., n. 69, 109 e YARSHELL, Flávio Luiz. Ação rescisória: juízos rescindente e rescisório, cit., n. 39, p. 129. 


\section{SENTENÇA DE MÉRITO}

\section{II.1. Introdução}

Com as alterações incluídas pela Lei n. 11.232/05, criou-se um novo paradigma no modelo processual até então vigente, denominado processo sincrético. Com a nova lei, o que antes era o processo de execução, passou a ser uma mera fase, que se inicia logo após o término da fase de conhecimento, e se opera sine intervallo, ou seja, a execução (ou melhor, cumprimento de sentença), passou a ser uma continuação natural do processo (isto é, fase) de conhecimento, desenvolvendo-se no mesmo processo e na mesma relação processual que o processo (fase) de conhecimento. O processo de execução de título judicial passou a se aplicar somente às execuções contra a Fazenda Pública (art. 730 do CPC) e de sentença que condena ao pagamento de prestação alimentícia (art. 732 do CPC), os demais casos de condenação em quantia, far-se-ão pelo cumprimento de sentença (art. 475-I e seguintes do CPC).

Assim, segundo a exposição de motivos ${ }^{142}$, em razão do novo modelo processual, por questão sistemática, impôs-se a alteração de demais artigos, dentre eles, o artigo 162 do Código de Processo Civil, que contém a definição legal de sentença. A partir de então, sentença passou a ser, de acordo com o parágrafo primeiro do referido artigo, "o ato do juiz que implica alguma das situações previstas nos arts. 267 e 269 desta Lei.”

Em razão das alterações sofridas, impõe-se verificar se houve alguma mudança substancial no conceito de sentença e quais seriam suas implicações, especialmente no que tange à sentença de mérito e ao sistema recursal, por estarem diretamente relacionados com o tema do presente estudo ou, se tais alterações não impuseram nenhuma modificação significativa ao conceito de sentença nem nenhuma consequência prática de relevo.

\footnotetext{
${ }^{142}$ Consta na exposição de motivos do projeto da referida lei que: “(...) b) a 'efetivação' forçada da sentença condenatória será feita como etapa final do processo de conhecimento, após um tempus iudicati, sem a necessidade de um 'processo autônomo' de execução (afastam-se princípios teóricos em homenagem à eficiência e brevidade processual); processo 'sincrético', no dizer de autorizado processualista. Assim, no plano doutrinário, são alteradas as 'cargas de eficácia' da sentença condenatória, cuja 'executividade' passa a um primeiro plano; em decorrência, 'sentença' passa a ser o ato "de julgamento da causa, com ou sem apreciação do mérito"; (...) f) a alteração sistemática impõe a alteração dos artigos 162, 269 e 463, uma vez que a sentença não mais 'põe fim' ao processo."
} 
Neste sentido, se mostra necessária uma primeira abordagem histórica do instituto, para melhor compreensão da controvérsia e a alcançarmos a exata dimensão das introduções trazidas pela novel legislação, bem como para servir de subsídio às conclusões a respeito do tema.

\section{II.2. Origens históricas}

No direito romano, no período das ações da lei, em que o iter processual dividia-se em duas fases, in iure e apud iudicem, a sentença era tida como um ato divino, no qual o iudex apenas declarava quem tinha razão ${ }^{143}$. Era através da litiscontestatio, a qual inicialmente tinha a natureza de contrato, que as partes escolhiam um árbitro (que era um cidadão romano), ao qual as partes submetiam a questão controvertida para ser decidida 144 . Dava-se, então, início a fase apud iudicem. O iudex limitava-se a dizer se procedia ou não a pretensão deduzida pelo autor, mas ele não podia executar o seu julgado, pois era destituído de imperium. Assim, era necessário recorrer-se novamente ao magistrado para o início da execução.

Posteriormente, no período clássico (ou per formulas), o processo desvinculou-se da influência religiosa, tornando-se laico. Era um processo menos formal, mas ágil e moderno, porém, conservava a bipartição do procedimento em duas fases (in iure e apud iudicem). Nessa época, a sentença sempre impunha uma condenação em dinheiro, não se concebendo a execução específica e, inicialmente, concedia-se um prazo de 30 (trinta) dias para cumprimento voluntário da condenação, passando a ser, posteriormente, de 60 (sessenta) dias 145 (tempus iudicati).

Ainda nesse período, surgiu a figura das denominadas praeiudicia, que consistiam em questões ou processos que exerciam determinada influência em relação a outros processos ou à decisão que viesse a ser proferida no mesmo processo. Inicialmente essas questões eram decididas através de uma pronunciatio, passando, depois, a ser

\footnotetext{
${ }^{143}$ NORONHA, Carlos Silveira. Sentença civil: perfil histórico-dogmatico. São Paulo: Ed. Revista dos Tribunais, 1995. p. 111 e ss.

144LIEBMAN, Enrico Tullio. Embargos do executado. Oposição de mérito no processo de execução. Tradução da 2. edição italiana por J. Guimarães Menegale. São Paulo: Saraiva, 1952. p. 20.

145DINAMARCO, Cândido Rangel. Execução civil. 5. ed. São Paulo: Malheiros Ed., 1997. p. 53.
} 
decididas por uma interlocutio. Nem a pronunciatio nem a interlocutio tinham a característica de sentença 146 .

Durante o período da extraordinaria cognitio o processo tornou-se mais simples e não era mais dividido em fases, pois se desenvolvia totalmente perante o pretor, passando a ser integralmente uma atividade estatal. As questões prévias continuavam a ser decididas pelas interlocutiones e a sentença definitiva não era mais uma opinião do magistrado, mas um provimento que "aplicava a lei ao caso concreto."147.

Posteriormente, sob a influência do direito canônico, formou-se o direito comum. O processo da época era composto por fases estanques (termini) e, ao final de cada uma, era proferida uma sentença interlocutória, cuja origem se deu com base nas praeiudicia do período clássico. Porém, o processo era resolvido, em seu conjunto, pelas sentenças definitivas 148 .

Já na legislação lusitana, no período das Ordenações, as sentenças classificavam-se em definitivas e interlocutórias. As definitivas eram proferidas após a revelação do resultado das provas e após as partes apresentarem suas razões finais, e decidiam a questão principal, condenando ou absolvendo o réu. As segundas eram aquelas que decidiam algum incidente da causa, e se dividiam em interlocutórias simples e mistas. Através das interlocutórias simples se decidia unicamente o incidente, e não se estendiam além dos limites do ponto sobre os quais eram proferidas. As interlocutórias mistas ocorriam na hipótese de, se com a decisão do incidente, a causa ficava prejudicada ou punha fim ao processo e à instância (Ordenações Filipinas 3.65. pr., 3.65.1 e 3.69.pr). A sentença interlocutória mista tinha força de definitiva.

No direito brasileiro, o Regulamento 737 manteve a estrutura fundamental das regras das Ordenações no que tange à classificação das sentenças, subsistindo o critério da bipartição das sentenças em definitivas e interlocutórias e, posteriormente, os códigos estaduais também mantiveram essa mesma estrutura básica ${ }^{149}$.

O Código de Processo Civil de 1.939 rompeu com a tradição secular de classificação das sentenças, haurida desde as épocas mais remotas do direito romano, e

\footnotetext{
${ }^{146}$ NORONHA, Carlos Silveira. Sentença civil: perfil histórico-dogmatico, cit., p. 119.

${ }^{147}$ Sentença civil: perfil histórico-dogmatico, cit.

${ }_{148}^{148}$ Sentença civil: perfil histórico-dogmatico, cit., p. 148 e ss.

${ }^{149}$ Sentença civil: perfil histórico-dogmatico, cit., p. 261 e ss.
} 
introduziu um novo paradigma no direito pátrio, nomeando os atos judiciais, para fins de recurso e verificação da coisa julgada em: acórdãos, sentenças definitivas, sentenças terminativas, sentenças interlocutórias (que continuavam a ser divididas em simples e mistas) e despachos (ou despachos de expediente) ${ }^{150}$. O sistema recursal implementado pelo Código de 1939 era assistemático e não primava pela clareza, motivo de inúmeras controvérsias e incertezas entre os operadores do direito.

Portanto, historicamente, a sentença definitiva sempre foi ato reservado ao momento final da demanda, e as questões decididas no curso do processo não ultrapassavam os limites da lide.

\section{II.3. O Código de Processo Civil de 1973}

Quase que em uma reação à legislação processual de 1939, o Código de 1973 simplificou a questão dos provimentos judiciais, nos seguintes termos: os provimentos 151 judiciais eram divididos em sentenças, decisões interlocutórias e despachos. Sentença era "o ato pelo qual o juiz põe termo ao processo, decidindo ou não o mérito da causa." (redação original do art. $162, \S 1^{\circ}$ ). Estabeleceu-se, ainda, a apelação como recurso próprio contra as sentenças, fossem elas terminativas ou de mérito, unificando e simplificando o sistema recursal.

A identificação da sentença de mérito, por sua vez, vinha estabelecida no artigo 269, da seguinte forma: "Extingue-se o processo com julgamento de mérito:". Portanto, percebe-se que o critério utilizado pelo Código de 1973 para definição de sentença era topológico, ou seja, levava em consideração o momento em que era proferida no iter processual, o que, no mínimo, facilitou o trabalho dos operadores do direito, pois, através das normas estabelecidas, distinguia-se, com facilidade, a sentença dos demais pronunciamentos judiciais, além de haver regras claras quanto ao recurso cabível e quanto à formação da coisa julgada material, com consequências significativas para a possibilidade de propositura da ação rescisória.

\footnotetext{
${ }^{150}$ NORONHA, Carlos Silveira. Sentença civil: perfil histórico-dogmatico, cit., p. 271. Porém, nessa época, nem mesmo a doutrina se entendia sobre quais seriam, ao certo, os atos judiciais.

${ }^{151}$ Segundo indicação do professor Dinamarco, a redação do art. 162 é falha, por contemplar somente os provimentos judiciais e não os atos, nos quais estariam inseridos também os atos materiais, in Instituições de direito processual civil, cit., v. 2, p. 503 e ss.
} 
Não obstante a clareza da regra processual, esta carecia de precisão, pois, salvo raras hipóteses em que não houvesse recurso, a sentença não punha fim ao processo, dado que, geralmente, a essa se seguia um recurso, que dava continuidade ao processo nas instâncias superiores e, ainda assim, mesmo que recurso não houvesse, não seria em razão da sentença que o processo se extinguiria, mas com o decurso de prazo para qualquer recurso (e a formação da coisa julgada formal ou material).

De qualquer forma, ainda que a definição fosse imprecisa, resolveu-se, de maneira satisfatória, o problema do meio adequado para a impugnação das decisões e o da ocorrência da coisa julgada material, anteriormente existente, quando ainda em curso o Código de 1939.

Segundo Alfredo Rocco, em clássica obra sobre a matéria, sentença era definida como: "o ato com o qual o estado, por meio de seu agente (o juiz), aplicando a norma ao caso concreto, declara a tutela jurídica que o direito objetivo concede a um determinado interesse."152. O conceito em tela adota como critério o substancial, ou seja, leva em consideração o conteúdo do ato. Liebman também adota o critério substancial ao qualificar a sentença como aquele ato "contendo a formulação da vontade normativa do Estado para o caso submetido a julgamento."153.

A doutrina da época, ainda que apontando as incorreções, utilizava-se, de um modo geral, da definição legal para conceituar a sentença. Neste sentido, Dinamarco esclarecia: "No direito positivo brasileiro, contudo, sentença tem um sentido mais amplo (art. 162, $\$ 1^{\circ}$ ). Abrange o ato judicial que põe fim ao processo mediante julgamento direito da pretensão trazida pelo autor (sentença de mérito: procedência, improcedência ou procedência parcial da demanda - CPC, art. 459) e também aquele com que o juiz. extingue sem julgar o mérito, ou sentença terminativa (...). Não é inteiramente correta a assertiva, contida na lei, de que a sentença é o ato que põe fim ao processo. Nem sempre ela chega a produzir esse efeito: quando é interposta apelação, o julgado que o tribunal proferir pôr-se-á no lugar da sentença e a substituirá por completo (art. 512), o que significa que a extinção será efeito dele e não dela. Melhor, portanto, será definir a sentença com ato cujo efeito processual é a extinção do processo, sabendo-se que esse

\footnotetext{
${ }^{152}$ Apud NORONHA, Carlos Silveira. Sentença civil: perfil histórico-dogmatico, cit., p. 275.

${ }^{153}$ LIEBMAN, Enrico Tullio. Manual de direito processual civil. Tradução e notas de Cândido R. Dinamarco. Rio de Janeiro: Forense, 1984. v. 1, p. 242.
} 
efeito será ou não produzido efetivamente, na dependência conforme o vencido permita ou impeça que ela passe em julgado."154

\section{II.4. Esclarecimentos sobre mérito e questão de mérito}

Antes de ingressarmos no tema relativo à nova conceituação de sentença de mérito, conforme as alterações legislativas introduzidas pela Lei n. 11.232/05, cumpre-nos fazer uma distinção inicial acerca de mérito e questões de mérito.

Todo processo tem um objeto em torno do qual as atividades processuais se desenvolvem e que limita a atuação do juiz. O processo se inicia com a demanda ajuizada e é através dela que o autor expõe a situação da vida sobre a qual reclama uma tutela jurisdicional do Estado. Assim, é a demanda que define o objeto do processo, ou a res in judicium deducta. A doutrina moderna reconhece a definição do objeto do processo como sendo o da pretensão deduzida em juízo ${ }^{155}$, ou melhor, "é a pretensão a um bem da vida, quando apresentada ao Estado-juiz em busca de reconhecimento ou satisfação"156.

Para resolver o mérito, o juiz, por expressa disposição constitucional, deve motivar a sua decisão (art. 93, IX, da Constituição Federal) e, para tanto, deve enfrentar uma série de questões, que são antecedentes lógicos da decisão final, podendo ser questões prejudiciais à decisão final. Tais questões, por expressa determinação legal contida no artigo 458, II do Código de Processo Civil, devem ser decididas na motivação da sentença, e com o mérito não se confundem 157 . Porém, certas vezes, e de modo equivocado, algumas dessas questões são decididas através de decisões interlocutórias, em um desvirtuamento do comando legal e do sistema processual ${ }^{158}$.

\footnotetext{
${ }^{154}$ DINAMARCO, Cândido Rangel. A instrumentalidade do processo. São Paulo: Malheiros Ed., 2004. p. 492 e ss.

${ }^{155}$ Ver por todos, DINAMARCO, Cândido Rangel. Instituições de direito processual civil, cit., v. 2, esp. p. 111 e ss. e 185 e ss.

${ }^{156}$ DINAMARCO, Cândido Rangel. Instituições de direito processual civil, cit., v. 2, p. 185.

${ }^{157}$ Não obstante o inciso III da mesma norma referir, de maneira inapropriada, que no dispositivo o juiz resolverá as questões que as partes lhe submeterem. Como se sabe, no dispositivo o juiz somente resolve o mérito propriamente dito, ou seja, o petitum, pois as questões de mérito são enfrentadas (e resolvidas) no fundamento da sentença.

${ }^{158}$ A esse respeito Dinamarco assinala: "É porém absolutamente contrário ao sistema a cisão consistente em apreciar uma das questões postas no processo, sem decidir sobre a procedência ou improcedência da
} 
Cabe fazer uma ressalva quanto a esse aspecto, a fim de diferenciar-se questões de mérito de questões preliminares. Estas últimas podem, ou melhor, devem ser decididas em momento anterior à sentença, e são questões, como o próprio nome indica, que devem ser conhecidas antes da decisão meritória, tais como: condições da ação e pressupostos processuais (são os chamados pressupostos de admissibilidade do julgamento do mérito). Geralmente, tais questões são decididas até o "despacho saneador" (que se trata de decisão interlocutória) 159 .

\section{II.5. Alterações introduzidas pela Lei n. 11.232/05}

Com a introdução do denominado processo sincrético, o legislador pátrio viu-se obrigado, por uma questão de coerência lógica, a alterar o conceito de sentença anteriormente em vigor. A nova lei deixou de conceituar propriamente a sentença, limitando-se a indicar as hipóteses de sua ocorrência, passando o parágrafo primeiro do artigo 162, do Código de Processo Civil, a ter a seguinte redação: "sentença é o ato do juiz que implica alguma das situações previstas nos arts. 267 e 269 desta Lei”.

A primeira crítica que a doutrina fez à nova lei, de forma unânime, foi em relação à imperfeição da terminologia empregada, uma vez que o vocábulo "implica" carece de sentido na frase. Com efeito, Barbosa Moreira esclarece que nenhuma das acepções do vocábulo se aplica à hipótese legal 160 .

Como se verifica, a nova redação do artigo $162, \S 1^{\circ}$ do Código de Processo Civil não seguiu mais o critério topológico, adotando o conteúdo do ato para indicar as hipóteses de sua ocorrência.

demanda ou mesmo pela denegação do julgamento do mérito. Todas as questões relacionadas com o mérito devem ser julgadas em um ato só...” in Instituições de direito processual civil, cit., v. 3, p. 700 e ss. 159

Caso algumas dessas questões sejam acolhidas, darão ensejo à sentença terminativa, não obstante forte corrente doutrinária no sentido de se reconhecer o caráter meritório de decisões a respeito das condições da ação. A respeito, ver COSTA, Susana Henriques da. Condições da ação. São Paulo: Quartier Latin do Brasil, 2005.

${ }^{160}$ "Dentre as acepções em que 'implicar' é transitivo direto, colhem-se nos dicionários duas em que se poderia pensar: uma delas é 'dar a entender, fazer supor, pressupor'; outra, 'trazer como consequência, envolver, importar'. Nenhuma das duas, todavia, permite conclusão positiva sobre o teor emendado do art. $162, \S 1^{\circ}$.

A sentença não 'dá a entender', não 'pressupõe', nem 'traz como conseqüência' ou 'importa' as hipóteses arroladas nos arts. 267 e 269.” "A nova definição...”, p. 174. 
Como já salientado anteriormente no tópico introdutório do presente capítulo (especialmente nota 1), a exposição de motivos da Lei n. 11.232/05 deixou claro que as alterações legislativas, particularmente no que tange ao artigo $162, \S 1^{\circ}$ do Código de Processo Civil, deram-se exclusivamente em razão da introdução do processo sincrético no sistema e, a partir de então, tecnicamente a sentença não mais põe fim ao processo, não sendo mais adequada, a partir de então, a antiga redação do dispositivo legal em comento.

Parece-nos que a exposição de motivos é clara o suficiente ao afirmar que a alteração se fez necessária, única e exclusivamente, por questões de ordem sistemática, uma vez implementada a fase de cumprimento de sentença, a qual se opera sine intervallo, não deixando margens a dúvidas quanto à razão de tal alteração. Ainda que a redação não prime pela clareza e precisão, a exposição de motivos não permite conclusão diversa, a qualquer pretexto.

Assim, a leitura dos termos da exposição de motivos da Lei n. 11.232/05 não autoriza conclusão pela alteração substancial no conceito de sentença, pois não foi esse o escopo da alteração legislativa. Cabe agora analisar se, por algum outro motivo, se pode concluir de forma diversa.

Ademais, caso realmente o legislador pátrio pretendesse fazer alguma alteração de substância em relação às sentenças, no sentido de que estas não necessariamente tivessem que se localizar no final da fase ou processo de conhecimento, podendo ser, como advogam alguns, cindida em várias decisões no curso do processo, deveria também ter excluído a expressão "extingue-se o processo", do artigo 267 do Código de Processo Civil.

Ora, caso fosse mesmo a intenção do legislador que a sentença pudesse ser cindida em tantas decisões quanto fossem os seus capítulos, não importando em que momento fosse proferida, as alterações deveriam ter atingido também o citado artigo, pois poder-se-ia, perfeitamente, imaginar uma demanda com pedidos cumulados, em que, em relação a um desses, fosse proferida uma sentença terminativa no curso do processo.

Mas, se o legislador não agiu dessa maneira, pode-se concluir que a sua intenção não era a de permitir que várias "sentenças" fossem proferidas num mesmo processo (ou fase) de conhecimento, revelando sua intenção de que "sentença" deve, sempre, pôr fim a uma fase ou processo. Assim, a interpretação sistemática do Código revela que o legislador não pretendeu classificar como sentença as eventuais decisões 
proferidas no curso da demanda e que poderiam ter o conteúdo de alguma das matérias do artigo 269, pois, se assim pretendesse, deveria também ter feito em relação às matérias do artigo 267, no qual manteve a expressão “extinção do processo". Seria muito casuísmo fazer-se diferenciação entre as sentenças terminativas e as sentenças de mérito somente pelo aspecto topológico.

Finalmente, outro argumento a favor da interpretação no sentido de que não foi a intenção do legislado de que a sentença de mérito não mais se situaria no final do processo (ou fase) de conhecimento, é que não foi alterada a nomenclatura do Capítulo III, do Título VI do Código de Processo Civil, que continua a ser "Da Extinção do Processo". Caso o legislador pretendesse realmente que a sentença de mérito não pusesse fim à fase de conhecimento, deveria, também, ter alterado a denominação do Capítulo III, o que não fez.

Dessa forma, parece que restou plenamente demonstrado que o propósito do legislado não foi o de provocar alterações de monta no sistema processual brasileiro em relação à conceituação de sentença. Porém, cumpre analisarmos se, apesar disso, existem elementos suficientes que permitam conclusão em sentido contrário, ou seja, de que, na prática, houve alteração.

\section{II.6. Princípio da unicidade da sentença}

Resta-nos examinar, em não sendo essa, entretanto, a real vontade do legislador, se efetivamente, com as novas alterações introduzidas na legislação processual, pode-se concluir pela possibilidade de entender como sentença de mérito as decisões proferidas no curso da demanda e que contenham alguma das matérias previstas no artigo 269 do Código de Processo Civil.

Conclusão nesse sentido não seria possível em razão do "princípio da unicidade da sentença" inserido no nosso ordenamento jurídico. O referido princípio decorre das normas do artigo 458, II e 459 do Código de Processo Civil, que determinam que o juiz deve resolver o mérito e todas as questões a ele pertinentes (de fato e de direito), no mesmo ato.

Neste sentido é o entendimento do professor Dinamarco, que preleciona, "Todas as questões relacionadas com o mérito devem ser julgadas em um ato só, como 
emerge do comando contido no art. 459 do Código de Processo Civil. É na sentença que o juiz acolhe ou rejeita, no todo ou em parte, o pedido formulado pelo autor (art. 459). Essa prática transgride também o disposto no art. 458, inc. II, do Código de Processo Civil, segundo o qual é na motivação da sentença que o juiz deve examinar as questões relativas ao meritum causae. Tal é o princípio da unidade estrutural da sentença, que só pode ser contrariado quando uma específica norma de direito o autorizar (Liebman)."161.

Luiz Guilherme Marinoni também reconhece a incidência do princípio, ao asseverar que, "De lado a tutela antecipatória, não é possível a cisão do julgamento dos pedidos cumulados, ou o julgamento antecipado de parcela do pedido, prevalecendo o princípio chiovendiano 'della unità e unicità della decisione."'162. Porém, aponta como solução à eventual demora do processo, quando um dos pedidos já estiver "maduro" para julgamento e os demais dependerem de dilação probatória, a utilização da técnica da tutela antecipada, com fulcro no artigo 273, $\S 6^{\circ}$, do Código de Processo Civil, lembrando que tal decisão terá caráter provisório e não estará apta a fazer coisa julgada material ${ }^{163}$.

Portanto, o princípio em tela impede entender como possível a cisão da sentença ou mesmo de se entender que, qualquer decisão que verse sobre as matérias do artigo 269 do Código de Processo Civil, antes do julgamento final da demanda, seja classificada como sentença.

Tal entendimento se mostra, inclusive, mais adequado ao atual sistema recursal previsto no ordenamento jurídico, uma vez que não se promoveu qualquer alteração no mesmo, que pudesse conduzir à possibilidade da existência de uma "sentença interlocutória”, pois, tal sentença seria impugnada por meio de apelação (art. 513, CPC) e, visto que a apelação determina a remessa dos autos à instância superior, como se processaria tal recurso, ou ainda, como se conceberia a continuidade do processo em

\footnotetext{
${ }^{161}$ DINAMARCO, Cândido Rangel. Instituições de direito processual civil, cit., v. 3, p. 700 e ss.

${ }^{162}$ MARINONI, Luiz Guilherme. Tutela antecipatória e julgamento antecipado: parte incontroversa da demanda. São Paulo: Ed. Revista dos Tribunais, 2002. p. 139, g.n. Continua o referido autor: "Se o processo deve prosseguir, não obstante a evidência de um direito, a tutela antecipatória (art. $273, \S 6^{\circ}$ ) é o único instrumento, dentro do atual sistema processual, que permite que o procedimento comum atenda ao direito constitucional à tempestividade da tutela jurisdicional, evitando que o autor seja obrigado a esperar indevidamente a tutela de um direito incontrovertido." (p. 157, g.n.).

${ }^{163}$ "No direito brasileiro, em hipóteses como a do exemplo narrado no início deste item, é possível a tutela antecipatória de parcela do direito postulado pelo autor. Trata-se de uma espécie de julgamento antecipado parcial do pedido, que pode ser feito a partir do art. $273, \S 6^{\circ}$, do CPC. A tutela, exatamente porque deve ser concedida nos limites da quantia provada, é fundada em cognição exauriente, e não em cognição sumária, embora possa ser revogada ao final do procedimento (art. 273, § $4^{\circ}$, do CPC)." MARINONI, Luiz Guilherme. Tutela antecipatória e julgamento antecipado: parte incontroversa da demanda, cit., p. 153.
} 
primeira instância? São questões que não foram resolvidas pela legislação, justamente porque este não foi o seu intuito (de instituir a figura da "sentença interlocutória").

Ademais, o sistema de divisão do processo (agora fase) de conhecimento em "subfases", a saber, postulatória, ordinatória, instrutória e decisória, que se distinguem pela predominância da prática de atos característicos em cada uma dessas fases (assim, na fase decisória que se praticam preferencialmente os atos decisórios) e, sendo a sentença um ato decisório por excelência, não haveria lugar para a realização de tal ato em outra fase que não a decisória. Portanto, o momento próprio para a prolação da sentença seria a fase decisória, que se situa no final do procedimento, justamente por ser decorrência lógica e a síntese de todas as fases precedentes.

Assim sendo, conclui-se, da mesma forma, não ser viável a cisão do julgamento em "sentenças intelocutórias", ou mesmo que, qualquer decisão que se situe no curso da demanda fora da decisão final, seja uma sentença de mérito, ainda que verse sobre qualquer das matérias do artigo 269, do Código de Processo Civil, em razão do princípio da unicidade da sentença. Reforçando tal entendimento, ainda, o fato de o sistema recursal vigente não dispor de meios adequados para impugnar as denominadas "sentenças interlocutórias".

\section{II.7. Identificação da sentença de mérito}

O vocábulo sentença, etimologicamente, deriva do verbo latino sentire, ou, mais especificamente, do gerúndio do referido verbo (sentiendo), que originou a expressão sententia no direito romano 164 . O termo indica que a sentença deve conter o modo como o juiz "sente a causa"165. Couture esclarece que quando tomamos nas mãos uma "sentença", temos em mãos somente a documentação do que efetivamente o juiz sentiu da

\footnotetext{
${ }^{164}$ Vale ressaltar os esclarecimentos de Noronha a respeito: "Diante de tal origem, torna-se fácil conceber que a semântica da palavra expressa sentimento ou a sensibilidade de quem se encontra diante de determinado fato para alcançar a inteligência e o conteúdo desse fato." NORONHA, Carlos Silveira. Sentença civil: perfil histórico-dogmatico, cit., p. 274.

${ }^{165}$ Expressão usada por Dinamarco, in Instituições de direito processual civil, cit., v. 2, p. 507.
} 
causa, mas não ela própria, pois "esta, originariamente, é algo que foi sentido, daí seu nome de sentença."166

Tornou-se clássica a definição de sentença de Chiovenda, segundo o qual esta "é a provisão do juiz que, recebendo ou rejeitando a demanda do autor, afirma a existência ou a inexistência de uma vontade concreta da lei que lhe garanta um bem ou respectivamente a inexistência ou existência de uma vontade de lei que garanta um bem ao réu."167. Tal definição refere-se à sentença de mérito, que é a que assume relevo para o presente trabalho.

Sentença, de um modo geral, é definida por Dinamarco como sendo "o ato com o qual o juiz define a causa com ou sem julgamento do mérito. Definir a causa é emitir a solução final referente ao litígio posto em juízo, dissolvendo seu objeto porque a respeito deste é então dada toda a resposta que naquele grau de jurisdição poderia ser dada."168 169 .

Sentença de mérito é aquela que se manifesta sobre o objeto do processo (pretensão), decidindo-o de maneira definitiva, apta a ensejar a extinção da fase de conhecimento.

Uma vez que a sentença de mérito é aquela que se manifesta sobre o objeto do processo, resolvendo a questão de direito material em litígio, conforme anteriormente ressaltado, alguns tribunais usam terminologia imprópria, pois, não raro, embora decidam o mérito da questão (negando provimento ao recurso), consignam não ter conhecido do recurso (terminologia reservada somente às matérias preliminares, portanto, que não analisa o mérito) 170 .

Referido expediente também é muito utilizado nos casos de indenização de acidente de trânsito quando o ofendido propõe a ação contra o antigo proprietário do

${ }^{166}$ COUTURE, Eduardo J. Introdução ao estudo do processo civil, cit., p. 75.

${ }^{167}$ CHIOVENDA, Giuseppe. Instituições de direito processual civil, cit., p. 198.

${ }^{168}$ DINAMARCO, Cândido Rangel. Instituições de direito processual civil, cit., v. 2, p. 508.

${ }^{169}$ Interessante transcrever as palavras de Dinamarco a respeito, em outra passagem: "Ao julgar o mérito nas hipóteses do art. 269 ou ao negar esse julgamento nas do art. 267, o juiz está dando à causa posta em juízo o fim que ela merece - e daí a conceituação de sentença como ato que define a causa." In DINAMARCO, Cândido Rangel. Instituições de direito processual civil, cit., v. 3, p. 681.

${ }^{170}$ A questão reflete diretamente na matéria da ação rescisória e é objeto da Súmula 249/STF, que possui a seguinte redação: "É competente o Supremo Tribunal Federal para a ação rescisória, quando, embora não tendo conhecido do Recurso Extraordinário, ou havendo negado provimento ao agravo, tiver apreciado a questão federal controvertida." 
veículo, que ainda consta nos registros dos órgãos oficiais. Na realidade, seria a hipótese de improcedência da demanda, uma vez que o direito material impõe o dever de indenizar pelo dano causado em razão de acidente, ao proprietário do veículo e não o ex-proprietário. Porém, algumas decisões acabam por julgar a demanda extinta por ilegitimidade de parte, solução em desacordo com a técnica processual.

Tratando da questão, Humberto Theodoro Júnior ressalva que: “ $O$ que importa, destarte, é verificar se o juiz examinou ou não o pedido, sendo irrelevante a forma verbal com que o acolheu ou rejeitou. Assim, por falta de técnica, é muito comum na praxe forense sentenças que declaram o autor carecedor da ação justamente porque não conseguiu provar a existência do direito material reclamado na propositura da causa, ou mesmo porque restou demonstrado que o autor não é o titular do mesmo direito."171.

Outra questão de relevo para a disciplina da ação rescisória são as chamadas “falsas sentenças de mérito"172 173, ou seja, aquelas em que, de fato, o juiz não decide o mérito, no entanto, a lei estipula como se de mérito fossem, pois, efetivamente, o pronunciamento judicial não se debruça sobre o mérito da causa, ou seja, sobre a pretensão deduzida em juízo.

Tais sentenças, enumeradas no artigo 269 do Código de Processo Civil, são as que homologam o reconhecimento da procedência do pedido pelo réu (inciso II), homologam transação das partes (inciso III), pronunciam a decadência ou a prescrição (inciso IV) e homologam a renúncia ao direito do autor (inciso V).

Sendo assim, para caracterização da sentença de mérito, devem concorrer duas condições: (a) que esta tenha por conteúdo uma das hipóteses previstas no inciso do artigo 269 do Código de Processo Civil e (b) que ponha fim à fase de conhecimento. Verifica-se, portanto, que existe um critério misto para que o ato seja classificado como sentença de mérito, utilizando-se tanto do critério topológico, como do conteúdo do ato. Tais sentenças são aptas a fazer coisa julgada material e estão sujeitas à ação rescisória.

\footnotetext{
${ }^{171}$ THEODORO JÚNIOR, Humberto. Curso de direito processual civil, cit., p. 465. E continua o renomado autor: "Num caso como o figurado, para efeito de ação rescisória e de exceção de coisa julgada, a sentença terá de ser examinada e considerada como decisão de mérito, malgrado o emprego de termos e expressões inadequados pelo respectivo prolator." (p. 466).

${ }^{172}$ Ver a respeito, DINAMARCO, Cândido Rangel. Instituições de direito processual civil, cit., v. 3, p. 263 e ss.

${ }^{173} \mathrm{Ou}$ "sentenças de mérito atípicas", segundo terminologia usada por Teresa Wambier, in Nulidades de processo e da sentença. São Paulo: Ed. Revista dos Tribunais, 1997. p. 91 e ss.
} 
De outra parte, as decisões proferidas no curso do processo, ainda que decidam (equivocadamente) sobre o mérito (especialmente, v.g. que acolhem parcialmente a prescrição ou a decadência) e que, não põem fim à fase de conhecimento, não podem ser conceituadas como sentença, tratando-se de decisão interlocutória e, inclusive no que concerne ao regime recursal, devem sujeitar-se ao agravo de instrumento. Quanto à possibilidade de rescisão dessas decisões, examinaremos mais adiante. 


\title{
III.3. DEMAIS DECISÕES
}

\author{
III.1. Execução
}

Tradicionalmente, a execução é concebida como "a atividade desenvolvida pelos órgãos judiciários para dar a atuação à sanção"174, ou seja, para realizar praticamente a regra sancionadora, constituindo método destinado à obtenção da tutela satisfativa, razão pela qual a doutrina afirma que na execução existe um desfecho único, favorável ao exeqüente (nunca favorável ao executado), pois "todos os atos do procedimento destinam-se a preparar um provimento satisfativo do direito do exequente" 175 .

Nesse sentido é que sempre se afirmou que não existe julgamento do mérito na execução, pois a demanda executiva não se presta a julgamento algum, diversamente do processo de conhecimento. Porém, como ressalva Dinamarco, não significa que inexista mérito no processo executivo, nem se concebe a existência de um processo sem pretensão, a qual, na execução, é a satisfação de um interesse. O que não tem lugar na execução é exclusivamente o julgamento do mérito, assim, a sentença na execução jamais seria passível de fazer coisa julgada material ${ }^{176}$.

No entanto, gradativamente, a doutrina e a jurisprudência foram admitindo a alegação de matérias relacionadas ao mérito do processo de execução, dentro do próprio processo de execução, notadamente através da denominada "exceção de préexecutividade".

A exceção de pré-executividade é comumente aceita para veicular matérias passíveis de serem conhecidas de ofício, referentes às condições da ação, pressupostos processuais, e matérias que possuam provas pré-constituídas, ou seja, que não demandem dilação probatória, como, por exemplo, pagamento, novação, prescrição etc. Detarte,

\footnotetext{
${ }^{174}$ LIEBMAN, Enrico Tullio. Processo de execução. São Paulo: Saraiva, 1980. p. 4.

${ }^{175}$ DINAMARCO, Cândido Rangel. Execução civil, cit., p. 150-151.

${ }^{176}$ Em sentido contrário, Sérgio Rizzi, que se apóia em doutrina de José Frederico Marques, para quem a sentença proferida no processo de execução com fulcro nos incisos do art. 794 do CPC, trata-se de "sentença definitiva que incide sobre relação jurídica material, e cujos efeitos se tornam imutáveis, quando houver a coisa julgada.", in "RIZZI, Sérgio. Ação rescisória. São Paulo: Ed. Revista dos Tribunais, 1979. p. 17.
} 
forçoso reconhecer que, através do instrumento em tela, acabou-se por permitir a introdução de matéria de mérito na demanda executiva e, dessa forma, possibilitou-se a existência de julgamento do mérito na ação de execução que acarretará, via de consequência, a ocorrência de coisa julgada material nessas hipóteses, com todas as implicações dela decorrentes, tais como a possibilidade de ação rescisória contra a decisão nela proferida, efeito preclusivo etc.

Araken de Assis manifesta opinião contrária, basicamente por entender não haver cognição suficiente à formação da coisa julgada na execução, bem como por conceber que a sentença seria meramente extintiva da ação executiva177, o que não procede, pois, tratando-se de matéria exclusivamente de direito, a prova pré-constituída se mostra suficiente para o julgamento do mérito, tal qual no próprio processo de conhecimento, nos casos de julgamento antecipado, havendo decisão a respeito do mérito da execução. Negar o efeito da coisa julgada nessas hipóteses seria contra o sistema da coisa julgada que, atualmente, é perfeitamente aplicável à execução.

Barbosa Moreira entende que, somente em casos excepcionais a sentença de execução terá aptidão para produzir coisa julgada material, por exemplo, nas hipóteses de indeferimento da inicial quando se verificar, de plano, a prescrição 178 .

Ainda no que tange a eventual introdução de mérito no processo de execução (isto é, fase de cumprimento de sentença), parte da doutrina entende que a impugnação no cumprimento da sentença (do art. 475-J, $\S 1^{\circ}, \mathrm{CPC}$ ), instituída pela Lei $\mathrm{n}^{\mathrm{o}}$ 11.232/2005, constitui mero incidente processual à atual fase de cumprimento de sentença 179 , sendo que, para esses doutrinadores, passaria a haver mérito na fase de cumprimento de sentença, podendo esta revestir-se de coisa julgada material, nas hipóteses

\footnotetext{
${ }^{177}$ ASSIS, Araken de. Manual da execução. São Paulo: Ed. Revista dos Tribunais, 2009. p. 451 e ss. O autor gaúcho entende não haver a formação da coisa julgada nem nas hipóteses de julgamento da denominada exceção de pré-executividade, asseverando que: "apesar de rejeitada a exceção, ao devedor figurar-se-á lícito alegar a matéria, outra vez, nos embargos. É que, em caso de rejeição, só ocorrerá a preclusão, fenômeno interno ao processo executivo, jamais a eficácia da coisa julgada (art. 467), inexistente, sob qualquer circunstância, nos domínios executivos." (p. 1161 e ss.).

${ }_{179}^{178}$ BARBOSA MOREIRA, José Carlos. Comentários ao Código de Processo Civil, cit., p. 112.

${ }^{179}$ Filiam-se a essa corrente Athos Gusmão Carneiro e Teori Albino Zavascki. Segundo Carneiro: “...não mais assistirá ao devedor por título judicial a possibilidade de defender-se através de uma ação de embargos do devedor (com a natureza de "ação de conhecimento" intercalada), mas sim mediante impugnação aos atos executórios, isto é, mediante atividade meramente incidental, cuja apresentação, no prazo de quinze dias, não conduz a uma "nova" relação jurídica processual." in CARNEIRO, Athos Gusmão. Cumprimento da sentença civil. Rio de Janeiro: Forense, 2007. p. 67.
} 
em que decidir questão de mérito (veiculada através da impugnação), mesmo que proferida no curso da execução, ou seja, por decisão interlocutória 180 .

Conclui-se que as decisões proferidas no curso da execução (ou cumprimento de sentença) que versem sobre matéria meritória, são aptas a produzir a coisa julgada material, sujeitando-se, dessa forma, à ação rescisória, mesmo que não se trate de decisão final (sentença) ${ }^{181}$, quer se trate de decisões proferidas em razão da denominada "exceção de pré-executividade", quer proferidas no âmbito da impugnação ao cumprimento de sentença, quando se entender que esta constitui mero incidente à ação de execução, ou mesmo na sede da própria execução, quando a decisão proferida decidir a relação de direito material e, portanto, tiver aptidão a formar a coisa julgada 182 .

\section{III.2. Ação monitória}

Nas ações monitórias, o réu é citado, pode oferecer embargos, que se processarão pelo rito ordinário ${ }^{183}$. Caso o réu não pague nem ofereça embargos, “constituir-se-á de pleno direito o título executivo judicial, convertendo-se o mandado inicial em mandado executivo"184. Assim, surge a questão de se saber qual a natureza jurídica da decisão proferida em tais hipóteses, isto é, quando o réu permaneceu inerte, convertendo-se o mandado monitório em título executivo, uma vez que a decisão liminar é proferida inaudita altera parte e em sede de cognição sumária.

\footnotetext{
180

Para Zavascki: "Em qualquer hipótese, não interposto o adequado recurso ou esgotada a cadeia recursal, a matéria decidida estará definitivamente preclusa no processo. Mesmo quando enfrentada por decisão interlocutória, fará coisa julgada, o que significa que, decidindo o mérito, só poderá ser reformada ou anulada por ação rescisória, nos casos do art. 485 do CPC." In ZAVASCKI, Teori Albino. Defesas do executado. In: RENAULT, Sergio et al. (Coord.). A nova execução de títulos judiciais: comentários à lei 11.232/05. São Paulo: Saraiva, 2006. p. 143.

${ }^{181}$ É o caso, por exemplo, de acolhimento parcial da prescrição ou de reconhecimento de pagamento parcial da dívida.

${ }^{182}$ A essa mesma conclusão chega Flavio Yarshell, partindo das seguintes premissas para que a decisão proferida em sede de execução possa ser rescindida: (i) que haja cognição sobre a relação material; (ii) que essa cognição seja apta a exaurir os termos da controvérsia; (iii) declaração de direito com eficácia muito mais do que meramente processual, passível de se projetar para fora do processo, tornando-se estável (coisa julgada); e (iv) constituindo, assim, em julgamento do mérito, rejeitando a pretensão do exequente. (YARSHELL, Flávio Luiz. Ação rescisória: juízos rescindente e rescisório, cit., n. 69, p. 211 e ss.).

${ }^{183}$ Art. $1.102 \mathrm{c}, \S 2^{\circ}$, do CPC.

${ }^{184}$ Conforme caput do art. $1.102 \mathrm{c}$, do CPC.
} 
A doutrina é controvertida a respeito. Teresa Arruda Alvim Wambier e José Miguel Garcia de Medina ponderam que referida decisão não seria apta à formação da coisa julgada em razão de a cognição exercida neste momento ser apenas parcial, nessa medida, superficial ${ }^{185}$. Porém, a razão parece estar com Antonio Carlos Marcato, segundo o qual, ainda que a cognição seja sumária e o mandado emitido sem a oitiva da parte contrária, o mandado monitório "adquire eficácia similar àquela da sentença condenatória obtida no processo de cognição plena somente se e quando o réu se omitir"186, concluindo que o provimento jurisdicional proferido nessa situação possui natureza idêntica ao proferido no processo condenatório. Ademais, não é necessário para a formação da coisa julgada, que tenha havido efetivamente a cognição plena e exauriente, bastando que se tenha conferido oportunidade à parte contrária de inferir no julgamento ${ }^{187}$.

\section{III.3. Ações sobre relações continuativas}

Normalmente, o sistema processual não admite o julgamento de obrigações futuras, ainda não vencidas, pois não se pode aceitar o julgamento de fatos futuros. Porém, em relação às obrigações de trato sucessivo, a coisa julgada atinge tais obrigações, quando se relacionam com as obrigações presentes e exigíveis. O inciso I, do artigo 471 do Código de Processo Civil determina que, em se tratando de relação jurídica continuativa, sobrevindo modificação no estado de fato ou de direito, a parte poderá pedir revisão do quanto decidido, concluindo-se, portanto, que a coisa julgada atinge as prestações futuras, enquanto não alterado o estado de fato ou de direito.

$\mathrm{Na}$ realidade, havendo alteração no estado de fato ou mesmo de direito, haverá alteração da causa de pedir, sendo possível, dessa forma, a propositura de nova ação, diversa da anterior, com base na nova realidade que se instituiu, não se tratando de verdadeira revisão da ação ou da coisa julgada, mas de nova ação, que regulará a nova situação então vigente. Não se trata, portanto, de coisa julgada submetida à condição rebus

\footnotetext{
${ }^{185}$ In WAMBIER, Teresa Arruda Alvim; MEDINA, José Miguel Garcia. O dogma da coisa julgada: hipóteses de relativização. São Paulo: Ed. Revista dos Tribunais, 2003. p. 121 e ss.

${ }^{186}$ MARCATO, Antonio Carlos. O processo monitório brasileiro. São Paulo: Malheiros Ed., 1998. p. 81.

${ }^{187}$ À semelhança do que ocorre, por exemplo, nos processos de conhecimento que versem exclusivamente sobre direitos disponíveis em que o réu permanece revel, nem por isso a sentença deixará de ser revestida pela coisa julgada.
} 
sic stantibus, pois não haverá verdadeira "revisão" da coisa julgada que se formou anteriormente, mas a parte veiculará nova pretensão, com base em nova causa de pedir ${ }^{188}$, não abrangida pela coisa julgada que se formou na ação anterior. Também é imprecisa a redação do artigo 15 da Lei de Alimentos ao determinar que "a decisão judicial sobre alimentos não transita em julgado e pode a qualquer tempo ser revista, em face da modificação da situação financeira dos interessados", pois, do mesmo modo, haverá alteração da causa de pedir, e não revisão da decisão anterior, proferida com base nas condições existentes à época de sua prolação ${ }^{189}$.

Em relação à matéria tributária, é de se destacar a redação da Súmula 239 do Supremo Tribunal Federal que determina que a "decisão que declara indevida a cobrança de imposto em determinado exercício não faz coisa julgada em relação aos posteriores". No entanto, referida Súmula tem sua razão de ser em virtude da regra de que os motivos da sentença não fazem coisa julgada (artigo 469, I do CPC). Assim, se determinada decisão estabeleceu que uma certa norma que instituiu a cobrança de certo imposto é ilegal e, portanto, o imposto é indevido, tal decisão não impede a cobrança do referido imposto, do mesmo sujeito, nos exercícios subsequentes. Porém, a solução não se aplica caso a parte requeira que, sobre a questão da legalidade da norma, o judiciário se manifeste em ação declaratória incidental, nos termos do artigo $5^{\circ}$ e 470 do Código de Processo Civil, ou então, que o pedido de declaração de ilegalidade faça parte do pedido principal do requerente, pois, em tais hipóteses, a coisa julgada atinge, sem qualquer óbice, a declaração de ilegalidade da norma instituidora do tributo.

Como corolário do entendimento supra, conclui-se que, para haver a efetiva "revisão" da coisa julgada que se forma nas ações de estado, é possível (ou melhor, necessária) a propositura da ação rescisória, desde que presentes os requisitos previstos no artigo 485 e seguintes do Código de Processo Civil, uma vez que estas se submetem plenamente ao regime da coisa julgada material, a despeito da imprecisão contida nos textos legais, não se podendo interpretá-los de maneira literal, pois o que a lei ressalva, não é a "revisão" da coisa julgada que anteriormente se formara, mas a propositura de nova demanda.

\footnotetext{
188Neste sentido, TALAMINI, Eduardo. Coisa julgada e sua revisão, cit., p. 90.

${ }^{189}$ Aliás, como bem observa Flavio Yarshell, revisão e rescisão são conceitos completamente diversos. (Ação rescisória: juízos rescindente e rescisório, cit., n. 55, p. 174).
} 


\section{III.4. Ações de estado}

O artigo 472 do Código de Processo Civil determina que, nas causas relativas ao estado de pessoas, se houverem sido citados no processo, em litisconsórcio necessário, todos os interessados, a sentença produzirá coisa julgada em relação a terceiros. A primeira ressalva que se deve fazer ao texto legal concerne ao fato de que, se os "terceiros" foram citados no processo, em litisconsórcio, deixaram de ser qualificados como terceiros, passando a ser partes, sofrendo, assim, normalmente os efeitos da sentença, como parte que passaram a ser, estando sujeitos, outrossim, à coisa julgada que se formar no processo em que atuaram como partes e, por certo, possuem legitimidade para rescindir a coisa julgada à que se sujeitaram.

Quanto aos demais, terceiros efetivamente em relação à demanda que verse sobre ação de estado, não serão atingidos pela coisa julgada, porém, caso não tenham legítimo interesse, não poderão se opor legitimamente à formação da coisa julgada. Por exemplo, não poderão se opor à coisa julgada formada no divórcio do casal, os filhos havidos do casamento dissolvido, por total falta de interesse de agir. Do mesmo modo, caso algum filho havido fora do casamento mova ação de investigação de paternidade contra o pai ainda vivo, após o falecimento do pai, os demais filhos não podem se opor à condição de filho daquele que teve seu direito reconhecido por sentença transitada em julgado, pois, na época da demanda, o legitimado primário era o pai (então vivo), que teve plenamente garantido seu exercício de defesa de seus interesses, na demanda investigatória. Assim, no inventário dos bens deixados pelo pai, os filhos havidos do casamento não podem contestar a condição do filho havido de relacionamento com outra mãe e, portanto, não possuem legitimidade para propor a demanda rescisória.

\section{III.5. Processo cautelar}

Como é corrente na doutrina, os processos cautelares visam exclusivamente assegurar o resultado de outro processo, sendo entendidos como instrumentos dos instrumentos, pois se prestam a resguardar a utilidade de outro processo, justamente por isso, como é curial, a cognição exercida no âmbito da ação cautelar é superficial, pois se contenta com o fumus boni iuris. Dessa forma, os efeitos das sentenças nele produzidas são 
de natureza meramente processual, não estando, via de consequência, aptos a fazer coisa julgada material ${ }^{190}$. E, como o objeto da ação rescisória é justamente a sentença sobre a qual se operou a coisa julgada material, as sentenças proferidas nos processos cautelares não se sujeitam à impugnação por meio da ação rescisória.

Porém, existem algumas ações propostas sob o procedimento cautelar que, efetivamente, atuam sobre a relação material de forma definitiva, desvirtuando o real escopo das ações cautelares. São as denominadas cautelares "satisfativas". Nesse caso, tendo em vista que o intuito da medida não foi o meramente assecuratório, pode-se vislumbrar uma decisão de mérito em tais hipóteses e, assim, apta a fazer coisa julgada, passível de desconstituição via ação rescisória.

Outra hipótese que pode viabilizar a ação rescisória da sentença proferida em processo cautelar é quando esta acolher alegação de decadência ou prescrição do direito do autor, com fulcro na parte final do artigo 810, do Código de Processo Civil, decidindo matéria de natureza substancial ${ }^{191}$.

\section{III.6. Processos coletivos}

O regime da coisa julgada nos processos coletivos segue a regra estatuída nos artigos 103 e 104 do Código de Defesa do Consumidor, ou seja, fazem coisa julgada erga omnes no caso de interesses difusos, limitado ao grupo, categoria ou classe, na hipótese de ações coletivas stricto sensu e para beneficiar a vítima e seus sucessores nos casos de direitos individuais homogêneos, sendo que, nos dois primeiros casos, a rejeição da ação por insuficiência de provas, segundo entendimento de autorizada doutrina, não faz coisa julgada material ${ }^{192}$.

Assim, em princípio, a ação rescisória só será cabível nas hipóteses em que se verificar a ocorrência da coisa julgada material e só terão legitimidade para tanto as pessoas sobre as quais ela recair. Porém, nos casos em que a ação coletiva tenha sido

\footnotetext{
${ }^{190}$ Ver a respeito: DINAMARCO, Cândido Rangel. Instituições de direito processual civil, cit., v. 3, p. 312; BARBOSA MOREIRA, José Carlos. Comentários ao Código de Processo Civil, cit., p. 113.

${ }^{191}$ Neste mesmo sentido RIZZI, Sérgio. Ação rescisória, cit., p. 12 e ss.

${ }^{192}$ Ver a respeito, GRINOVER, Ada Pellegrini et al. Código brasileiro de defesa do consumidor comentado pelos autores do anteprojeto. Rio de Janeiro: Forense Universitária, 2007. esp. comentários aos arts. 103 e 104.
} 
julgada improcedente por insuficiência de provas (parte final dos incisos I e II do art. 103 do CPC), que prevê a possibilidade de propositura de nova ação, a coisa julgada somente não se formará quando a nova demanda se fundar em prova nova. Assim, mesmo em tais hipóteses, quando não se cuidar de nova prova, viável será o manejo da ação rescisória para atacar tais sentenças.

Nesse aspecto, cabe lembrar que, nos termos do artigo 16 da Lei de Ação Civil Pública (Lei $\mathrm{n}^{0}$ 7.347/85), não obstante as severas críticas que a sua redação sofreu 193 (acertadas, por sinal ${ }^{194}$ ), determinou-se que as sentenças proferidas com fulcro na referida lei, farão coisa julgada erga omnes nos limites da competência territorial do órgão prolator, salvo se o pedido for julgado improcedente por insuficiência de provas, quando a ação poderá ser reproposta, com base em prova nova. Tal situação deve ser considerada para fins da ação rescisória, pois somente aquelas pessoas atingidas pela coisa julgada terão legitimidade para propositura da ação rescisória.

\section{III.7. Decisões monocráticas proferidas com base no art. 557 do CPC}

A partir da edição da Lei ${ }^{0}$ 9756/98, que alterou a redação do artigo 557 do Código de Processo Civil e de seus parágrafos, passou-se a admitir que o relator pudesse, em certos casos, apreciar diretamente o mérito do recurso, para negar provimento ao mesmo. Cumpre ressaltar que, nas hipóteses de o relator entender tratar-se de recurso manifestamente inadmissível ou prejudicado, certamente não haverá julgamento do mérito. Nas demais hipóteses, poderá ocorrer o julgamento do mérito, desde que a matéria tratada no recurso cujo seguimento é negado, seja de mérito ${ }^{195}$.

\footnotetext{
${ }^{193}$ Ver a respeito as críticas da professora Ada Pellegrini Grinover, nos comentários ao art. 103 do CDC, especialmente n. 2A, p. 939 e ss., in Código brasileiro de defesa do consumidor comentado pelos autores do anteprojeto, cit.

${ }^{194}$ Não obstante as severas críticas que a alteração legislativa sofreu da doutrina (que alterou a redação do art. 16 da Lei de Ação Civil Pública inserindo a atual restrição territorial), em sede liminar na Ação Direta de Inconstitucionalidade $\mathrm{n}^{\circ} 1576 / \mathrm{DF}$, o Supremo Tribunal Federal entendeu pela constitucionalidade da norma. Todavia, a referida ação não teve seu mérito apreciado por falta de atendimento à determinação de aditamento da inicial.

${ }^{195}$ A terminologia empregada pode ensejar alguma dúvida, na medida em que a expressão "negar seguimento" imprime uma idéia de que o mérito do recurso não é examinado. Mas é justamente o contrário, somente analisando o mérito do recurso é que o relator poderá chegar à conclusão de cuidar-se de recurso manifestamente improcedente ou em confronto com súmula ou com jurisprudência dominante.
} 
Assim, se por qualquer razão a decisão do relator proferida com base no artigo 557 do Código de Processo Civil, sobre o mérito, transitar em julgado, não se exclui a possibilidade de se intentar ação rescisória. Conforme bem observado por Flavio Yarshell, a solução causa certa perplexidade, na medida em que, contra referida decisão não seria possível a interposição dos recursos especial e extraordinário, pois não estaria atendido ao requisito do esgotamento das vias ordinárias, o que não se exige para a ação rescisória 196.

\section{III.8. Decisões interlocutórias}

Com relação à possibilidade de se propor ação rescisória contra decisão interlocutória, há uma certa divergência na doutrina. Com efeito, como se disse anteriormente, a ação rescisória constitui um remédio excepcional e, justamente por isso, suas hipóteses de cabimento não podem ser interpretadas extensivamente ${ }^{197}$. Assim é que, conforme redação do caput do artigo 485 do Código de Processo Civil, estabeleceu-se como primeiro pressuposto para viabilizar a ação rescisória, que a decisão a ser rescindida fosse uma sentença de mérito.

Da mesma forma, afirmou-se que, não obstante o rol do artigo 485 do Código de Processo Civil tratar-se de rol taxativo, o fato não impediria que se desse interpretação extensiva aos termos da lei, a fim de revelar o verdadeiro alcance da norma.

Assim é que, em determinadas circunstâncias excepcionalíssimas, parte da doutrina entende ser possível a ação rescisória contra decisão interlocutória, quando essa, indevidamente, versar sobre mérito ou questão de mérito, apta, portanto, a influir na relação de direito material, assemelhando-se a uma sentença de mérito.

Com efeito, também restou esclarecido que, tanto o mérito da demanda (petitum) quanto as questões de mérito (antecedentes lógicos da decisão final) ${ }^{198}$, devem ser resolvidos na sentença. Todavia, pode ocorrer que, inadvertidamente, seja proferida alguma decisão no curso do processo, sobre questão de mérito, a qual acaba por influenciar o direito material das partes. A hipótese mais comum é a de rejeição da prescrição ou o reconhecimento da prescrição com relação a somente uma das partes constantes no

\footnotetext{
${ }^{196}$ YARSHELL, Flávio Luiz. Ação rescisória: juízos rescindente e rescisório, cit., n. 53, p. 166, nota 21.

${ }^{197}$ Vide capítulo II, da parte 2, do presente estudo.

${ }^{198}$ Ver a respeito capítulo II.4, da parte 3, do presente trabalho.
} 
litisconsórcio, excluindo-a e prosseguindo a demanda em face dos demais réus. Nessa medida, não havendo a extinção do processo, não se tratará de sentença 199 .

Para solucionar a questão, parte da doutrina entende que, a decisão proferida nesses termos se trata de uma "anomalia", já que o sistema não previu a solução de questões de mérito por decisão interlocutória 200 e, sendo assim, desde que presentes os demais requisitos, idealiza como solução a possibilidade de manejo da ação rescisória contra a decisão interlocutória em tais hipóteses excepcionais 201 , pois apesar de o ato judicial vazado nesses termos ser considerado formalmente como uma decisão interlocutória, substancialmente, em razão da matéria tratada, terá o teor de uma sentença.

Flavio Yarshell é de opinião diversa, asseverando não ser possível a demanda rescisória contra decisão interlocutória no caso específico de a decisão haver rejeitado alegação de prescrição ou decadência (ou que resolva qualquer "questão de mérito), pois, não obstante a lei tratar tais matérias como sendo de mérito, conforme artigo 269, IV, do Código de Processo Civil, não haverá, propriamente dita, apreciação do pedido, mas mera rejeição de matéria defensiva, não sendo possível qualificar tal decisão como "de mérito" para fins de ação rescisória. No entanto, em tais casos, entende ser viável a ação rescisória contra a sentença final, se contrária aos interesses a quem a prescrição ou a decadência aproveitaria. Antes disso, alega que não haveria sequer interesse da parte em aforar a demanda rescisória, visto que a demanda originária pode, por outras razões, ser rejeitada, tornando desnecessária a rescisão da sentença202 203.

\footnotetext{
${ }^{199}$ Ressalvado entendimento em contrário, daqueles que vislumbram que, com a nova redação do art. 162 do CPC, alterado pela Lei $\mathrm{n}^{\circ} 11.232 / 05$, o sistema passou a permitir a "sentença parcial" ou "sentença interlocutória", posição da qual discordamos (vide capítulo II da parte 3). Para quem se filia a essa corrente, o problema não existirá, pois entenderá que o ato judicial lavrado nesses termos cuida-se de sentença de mérito, não havendo os óbices do caput do art. 485 do CPC, ora apontados.$$
200
$$

Como bem observa Dinamarco, "Não passaria pela cabeça de ninguém, como não passou pela do legislador, que o juiz pudesse, ao longo do procedimento, ir selecionando as questões de mérito sobre as quais formasse sucessivamente seu convencimento, para de modo gradual eliminá-las uma a uma negando a compensação logo ao despachar a contestação, rejeitando o pagamento quando aprecia o requerimento de provas, afastando a prescrição ao sanear o processo etc." (DINAMARCO, Cândido Rangel. Nova era do processo civil. São Paulo: Malheiros Ed., 2003. n. 148, p. 285).

${ }^{201}$

Nesse sentido: DINAMARCO, Cândido Rangel. Nova era do processo civil, cit., p. 280 e ss; NERY JUNIOR, Nelson; NERY, Rosa Maria de Andrade. Código de processo civil comentado e legislação processual civil extravagante em vigor: atualizado até 15.03.200, cit., comentário ao art. 485, p. 800

202YARSHELL, Flávio Luiz. Ação rescisória: juízos rescindente e rescisório, cit., n. 64, esp. p. 201.

${ }^{203}$ Argumenta, ainda, em abono de sua tese, que não é necessário, para manejo da ação rescisória, que o vício alegado esteja na própria sentença passível de desconstituição, o que autorizaria, ou melhor, recomendaria, que a rescisória só fosse proposta ao final da demanda, contra a sentença. (Ação rescisória: juízos rescindente e rescisório, cit., n. 39, p. 129).
} 
Nesse contexto, impende ressaltar que o citado autor entende que nas hipóteses em que capítulos do mérito venham a ser apreciados no curso do processo (tais como, que aprecie: reconvenção, ação declaratória incidental, incidente de falsidade etc.), haverá verdadeira cisão da sentença (o ato terá julgado pedido - mérito -, e não questão de mérito), e assim, parece-lhe possível a desconstituição do ato, via ação rescisória, seja feita, igualmente, de forma desvinculada ${ }^{204}$, ou seja, contra a "decisão interlocutória" que se manifestou sobre o mérito.

\section{III.9. Decisões que decretam a carência de ação}

A questão das condições da ação ainda traz muitas dúvidas tanto na doutrina como na jurisprudência. O nosso Código de Processo Civil, adotando a teoria de Liebman 205 , estabelece que, ausentes quaisquer das condições da ação, o processo deve ser extinto, sem julgamento do mérito, considerando-as como "condições de admissibilidade do julgamento do pedido, ou seja, como condições essenciais para o exercício da função jurisdicional com referência à situação concreta deduzida em juízo"206.

Predomina na doutrina entendimento de que a verificação das condições da ação é feita à luz da relação de direito material ${ }^{207}$, ou seja, é a partir da relação material que se fará a verificação do preenchimento das condições da ação, sendo um ponto de contato do direito processual com o substancial 208 .

Nessa medida, a sentença de extinção do processo, por ausência das condições da ação, não estaria apta a formação da coisa julgada e, assim, essa sentença não

\footnotetext{
${ }^{204}$ YARSHELL, Flávio Luiz. Ação rescisória: juízos rescindente e rescisório, cit., p. 184 e ss.

${ }^{205}$ Ver a respeito nota do professor Dinamarco (nota 106, p. 160), no Manual de direito processual civil, cit. de Enrico Tullio Liebman, que esclarece que Alfredo Buzaid, discípulo de Liebman, incluiu as conhecidas três condições da ação hauridas das lições de Liebman, porém, um pouco antes da entrada em vigor do Código de 1973, o mestre reformulou a sua teoria sobre as condições da ação, excluindo dessa relação a possibilidade jurídica do pedido, que passou a ser encarado como ausência de interesse de agir.

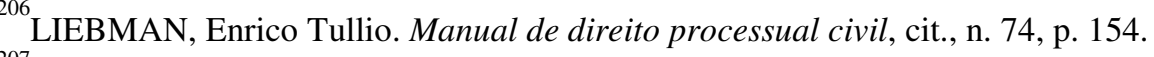

${ }^{207}$ Bedaque esclarece: "os dados para a verificação das condições da ação são todos fornecidos pelo direito material. Examinar condições da ação significa voltar os olhos para a relação jurídica de direito material”. (Direito e processo: influência do direito material sobre o processo, cit., p. 74).

${ }^{208}$ Neste sentido: DINAMARCO, Cândido Rangel. Instituições de direito processual civil, cit., v. 2, n. 542, p. 307.
} 
se sujeitaria à impugnação pela via rescisória, pois, não havendo julgamento do mérito, não haveria nenhum óbice a repropositura da mesma demanda. Porém, não é este o entendimento que parte da doutrina 209 e da jurisprudência 210 vem conferindo à figura das condições da ação.

Com efeito, vem ganhando espaço, tanto em sede doutrinária como jurisprudencial, a teoria no sentido de que as condições da ação configuram verdadeiro julgamento do mérito, pois seriam casos de manifesta improcedência ${ }^{211} \mathrm{e}$, sendo assim, configuraria julgamento de mérito, idôneo à formação da coisa julgada e, nessa medida, passível de impugnação pela demanda rescisória, o que nos afigura mais correto.

Nesse aspecto, não nos parece correto afirmar que a possibilidade da formação da coisa julgada dependerá da profundidade da cognição realizada no processo em que a decisão foi proferida 212 , pois não é esse o critério utilizado pela lei processual, visto que existem outras hipóteses em que, não obstante tenha havido cognição superficial 213 , a lei outorga à decisão o caráter de definitiva, reconhecendo a formação da coisa julgada.

Dessa forma, parece-nos possível afirmar que a decisão que extingue o processo por ausência de quaisquer das condições da ação, é apta a formar coisa julgada e, portanto, pode sujeitar-se ao controle da ação rescisória.

\footnotetext{
${ }^{209}$ Ver a propósito a obra de COSTA, Susana Henriques da. Condições da ação, cit.

${ }^{210}$ Vide, por exemplo, o entendimento esposado no Resp. n ${ }^{\circ}$ 278.598/MG, rel. Min. José Arnaldo da Fonseca, DJ 10/06/02, p. 242.

${ }^{211}$ Conforme bem observa Susana Costa, Condições da ação, cit. "As condições da ação têm um caráter eminentemente instrumental, pois identificam situações em que a pretensão do autor se mostra manifestamente improcedente. Em virtude dessa improcedência manifesta do pedido do autor, legitima-se o conhecimento do juiz de ofício da ausência dessas condições e o consequiente julgamento do mérito da demanda, com a solução definitiva do litígio e a pacificação social, fim último do direito processual.” (p. 98).

${ }^{212}$ Neste sentido, YARSHELL, Flávio Luiz. Ação rescisória: juízos rescindente e rescisório, cit., n. 51, esp. p. 162 e ss.

${ }^{13}$ Por exemplo, nas hipótese em que o juiz reconhece, de plano, a ocorrência da prescrição ou decadência, ou nos casos de julgamento antecipado da lide, em razão da revelia do réu.
} 


\section{III.10. Decisões do Juizado Especial Cível, decisões nas ações diretas de constitucionalidade e inconstitucionalidade e nas arguições de descumprimento de preceito fundamental}

Por expressa determinação legal 214 , não se admite ação rescisória das decisões proferidas na sede dos Juizados Especiais Cíveis. Tal disposição se deve em razão de ser o caráter excepcional da ação rescisória incompatível com a celeridade do trâmite imposto no âmbito do procedimento especial dos Juizados.

Nos casos em que a decisão de mérito do Juizado Especial Cível tenha sido proferida com algum dos vícios arrolados pelo artigo 485 do Código de Processo Civil, admite-se a impetração do mandado de segurança para o tribunal local, como forma de controle do ato 215 , inclusive, afastando em tais hipóteses, a incidência da Súmula 268 do Supremo Tribunal Federal, para viabilizar o direito de acesso à justiça à parte lesada 216 .

Não é cabível também a ação rescisória das decisões que declara a constitucionalidade ou a inconstitucionalidade da lei ou ato normativo em ação direta ou em ação declaratória 217 , bem como a decisão que julga procedente ou improcedente o pedido em arguição de descumprimento de preceito fundamental 218 .

No entanto, caso se verifique algum dos graves vícios enumerados nos incisos do artigo 485 do Código de Processo Civil, nas decisões proferidas nas ações acima referidas, não se deve pré-excluir outras formas de controle de tais decisões 219 que possam padecer de vícios de natureza tão grave, a ponto de comprometer seriamente o resultado do julgamento tão relevante para a nossa ordem jurídica.

\footnotetext{
${ }^{214}$ Art. 59, da Lei ${ }^{\circ}$ 9099/95.

${ }^{215}$ Neste sentido: STJ, RMS 30.170/SC, relatora Ministra Nancy Andrighi, DJe 13/10/10.

${ }^{216}$ A respeito, impende ressaltar que a Reclamação ao Superior Tribunal de Justiça, à qual não consta nenhuma restrição na lei dos Juizados Especiais Cíveis, não se presta ao papel de sucedâneo da ação rescisória, não sendo permitido seu uso nas hipóteses de trânsito em julgado da decisão reclamada.

${ }^{217}$ Art. 26, da Lei $n^{\circ} 9.868 / 99$.

${ }^{218}$ Art. 12 , da Lei $n^{\circ} 9.882 / 99$.

${ }^{219}$ Quer por mandado de segurança, quer por ação declaratória ou outra medida que se entender cabível.
} 


\section{III.11. Decisões homologatórias}

As sentenças homologatórias não são verdadeiras sentenças de mérito, pois, em tais hipóteses o juiz não aprecia a pretensão do autor, declarando a procedência ou improcedência da demanda, falando a doutrina em falsas sentenças de mérito ${ }^{220}$, porém, a lei processual atribui a essas sentenças o caráter de imutabilidade 221 , cunhando-as como sentenças de mérito, passíveis de receberem a autoridade da coisa julgada.

Destarte, recaindo sobre as mesmas a auctoritas rei judicatae, as sentenças homologatórias são passíveis de ação rescisória ${ }^{222}$. Porém, deve-se distinguir que, em semelhantes casos, haverá dois atos judiciais, os atos negociais, que põem fim ao litígio, e a sentença homologatória, sendo que somente esta última adquire a força da coisa julgada e, nessa medida, somente esta pode ser rescindida. Os atos das partes, como já asseverado anteriormente $^{223}$, podem ser desconstituídos, como os atos jurídicos em geral, nos termos da lei civil, através das vias ordinárias, através das quais se poderão alegar os vícios internos ao ato homologado.

Ainda no que tange às sentenças homologatórias, de acordo com autorizada doutrina, é possível rescindir-se também as decisões confirme ou negue homologação à sentença estrangeira ${ }^{22}$, pois não há nenhuma norma que estabeleça qualquer restrição a respeito.

\section{III.12. Jurisdição voluntária}

É noção corrente na doutrina que as ações de jurisdição voluntária não são aptas a produzir coisa julgada, uma vez que, nessas ações, não haveria conflito entre os

\footnotetext{
${ }^{220}$ Ver a propósito, DINAMARCO, Cândido Rangel. Instituições de direito processual civil, cit., v. 3, esp. n. 928 , p. 263 e ss.

${ }^{221}$ Uma vez que previstas nos incisos do art. 269, do CPC.

${ }^{222}$ Neste sentido: BARBOSA MOREIRA, José Carlos. Comentários ao Código de Processo Civil, cit., n. 82 e ss., p. 140 e ss; e DINAMARCO, Cândido Rangel. Instituições de direito processual civil, cit., v. 3, n. 928 e ss., p. 263 e ss.

${ }^{223}$ Vide capítulo I, da parte 2.

${ }^{224}$ BARBOSA MOREIRA, José Carlos. Comentários ao Código de Processo Civil, cit., n. 69. p. 116.
} 
sujeitos a ser decidido pelo juiz, inexistindo lide 225 e, nessa medida, não estariam sujeitas à ação rescisória 226.

Com relação à sentença proferida em sede de jurisdição voluntária, o artigo 1.111 do Código de Processo Civil determina que esta poderá ser modificada, sem prejuízo dos efeitos já produzidos, se ocorrerem circunstâncias supervenientes.

Como já visto em outras hipóteses, o fato de poder a sentença ser modificada por circunstâncias supervenientes não significa que estas não produzam coisa julgada, pois, havendo alteração na situação de fato e ensejar nova demanda, não se cuidará da mesma demanda, mas de outra em razão da alteração na causa de pedir 227 .

Diverge do entendimento majoritário da doutrina o professor Flavio Yarshell, pois, segundo seu entendimento, na jurisdição voluntária há atividade jurisdicional, contraditório, relação jurídica processual e mérito, bem como apreciação da situação substancial, o que seria apto a produzir coisa julgada e, como a sentença só poderia ser alterada no caso de nova causa de pedir, nas hipóteses em que esta nova causa inexistir, conclui o renomado autor que na dita jurisdição voluntária, a apreciação do seu mérito é apta a projetar efeitos para fora do processo, podendo adquirir um certo grau de estabilidade, a justificar a ação rescisória 228 , posição com a qual concordamos.

Ressalva ainda o professor das arcadas, a possibilidade de o próprio juiz, afastando a preclusão que se formou sobre sua decisão, com base no permissivo contido no artigo 1.109 do Código de Processo Civil, rever a decisão anterior, sanando eventual vício, sem que seja necessário para tanto ajuizar demanda rescisória, porém, tal procedimento nem sempre será possível de se realizar para sanar alguns dos vícios elencados nos incisos do artigo 485 do Código de Processo Civil, especialmente quando se tratar dos incisos I e II, em que os motivos do vício são imputáveis ao próprio julgador.

\footnotetext{
${ }^{225}$ Ver a respeito, Dinamarco, Instituições de direito processual civil, cit., v. 3, p. 312, porém, o próprio autor ressalva que, não há que se falar em inexistência de mérito, pois, não se poderia conceber um processo sem mérito, isto é, sem objeto.

${ }^{226}$ Neste sentido, BARBOSA MOREIRA, José Carlos. Comentários ao Código de Processo Civil, cit., n. 69 , p. 111.

Tal se dá à semelhança do que ocorre quando há alteração no estado de fato ou de direito a ensejar a "revisão do quanto decidido. Vide supra, n. 2, parte 3.

${ }^{228} \mathrm{O}$ autor ainda afasta a distinção entre as sentenças homologatórias da jurisdição voluntária, das sentenças homologatórias da jurisdição voluntária, igualando-as. (YARSHELL, Flávio Luiz. Ação rescisória: juízos rescindente e rescisório, cit., n. 56, esp. p. 179 e ss.).
} 


\section{BREVES CONSIDERAÇÕES SOBRE A AÇÃO RESCISÓRIA NO ANTEPROJETO DO CÓDIGO DE PROCESSO CIVIL}

Na exposição de motivos do anteprojeto do Código de Processo Civil, a comissão estabelecida para sua elaboração deixou bem clara a preocupação em conferir ao sistema uma maior coesão, (pois, diante das constantes e recentes alterações do ordenamento processual, ocorreu uma ruptura no sistema), bem como os valores pelos quais os trabalhos legislativos se pautaram, ressaltando, principalmente, a importância da questão da segurança jurídica.

Assumiu grande relevo o princípio da segurança jurídica na elaboração do anteprojeto, o que refletiu na disposição de vários mecanismos para sua proteção. Em particular, no que tange ao tema do presente trabalho, o princípio em questão trouxe como consequências práticas a não rescindibilidade de sentenças transitadas em julgado, baseadas em orientação abandonada pelo tribunal e a redução, em regra, do prazo decadencial da ação rescisória para um ano 229 230. Também constou na exposição de motivos, que para "desfazer "nós" do sistema", deixou claras as hipóteses de cabimento da ação rescisória e da ação anulatória, prevendo que todas as sentenças homologatórias somente seriam impugnáveis por ação anulatória.

Passando especificamente aos dispositivos que interessam ao presente trabalho, inicialmente parece que o anteprojeto resolveu a questão de saber se seria possível a cisão formal da sentença, proferindo julgamentos de mérito no curso da lide, revestidos do caráter de sentença, estabelecendo, no parágrafo primeiro do artigo $158^{231}$, que a sentença é o pronunciamento por meio do qual o juiz põe fim à fase cognitiva do procedimento comum, bem como extingue a execução. Assim, a nova legislação proposta

\footnotetext{
${ }^{229}$ Transcreve-se expressamente os termos da exposição de motivos: "Esse princípio tem relevantes consequências práticas, como, por exemplo, a não rescindibilidade de sentenças transitadas em julgado baseadas na orientação abandonada pelo Tribunal. Também em nome da segurança jurídica, reduziu-se para um ano, como regra geral, o prazo decadencial dentro do qual pode ser proposta a ação rescisória". Apesar de ter constado a impossibilidade de rescisão de sentença transitado em julgado com base em orientação abandonada pelo tribunal, a princípio, s.m.j., não localizamos referida regra no anteprojeto do $\mathrm{CPC}$.

O entendimento se liga intimamente à orientação contida na Súmula 343/STF, segundo a qual: "Não cabe ação rescisória por ofensa a literal disposição de lei, quando a decisão rescindenda se tiver baseado em texto legal de interpretação controvertida nos tribunais". Assim, a contrario sensu, é cabível a ação rescisória se a orientação não era mais controvertida à época da decisão rescindenda $(\mathrm{AgRg}$ na $\mathrm{AR}$ 4.439/PR, rel. Min. Luiz Fux, DJe 01/10/10).

${ }^{231} \mathrm{O}$ qual passou a ser o art. 170, após a aprovação do anteprojeto pelo Plenário do Congresso.
} 
põe fim à discussão acerca da possibilidade de cisão formal da sentença, pois esta deverá ser proferida sempre ao final da fase de conhecimento ou da execução.

A coisa julgada (material) vinha definida no artigo $483^{232}$, o qual, após a aprovação pelo Senado, passou a ser o artigo 489, que a conceitua como "a autoridade que torna imutável e indiscutível a decisão de mérito não mais sujeita a recurso" e, no artigo $487^{233}$ (que passou a ser artigo 493 após o trâmite no Senado), ao fixar os limites subjetivos da sentença, não incorre no mesmo erro do vigente Código de Processo Civil, que determina, contraditoriamente que, nas causas relativas ao estado de pessoas, se houver a citação de todos os interessados, a sentença faz coisa julgada em relação "a terceiros" 234 .

No anteprojeto, a ação rescisória vem disciplinada nos artigos 884 e seguintes 235 , com poucas alterações em relação ao Código de Processo Civil atualmente vigente. A primeira alteração que se faz sentir é quanto ao caput do próprio artigo $884^{236}$ que prescreve, de maneira mais adequada, que também o acórdão de mérito, transitado em julgado, pode ser rescindido. Essa alteração se deu somente para adequar a redação da regra ao quanto se verifica na prática, pois, mesmo com o texto atual, não há qualquer dúvida de que o acórdão (geralmente é o que mais ocorre na prática), também pode ser rescindido.

Todavia, a nova regra ainda peca pela imprecisão, pois deixou de lado a decisão monocrática proferida pelo relator com fulcro nos incisos III, IV e V, do artigo $853^{237}$, com o agravante de que, com a imposição de multa ao recurso de agravo interno contra essa decisão que for considerado "manifestamente inadmissível" (parágrafo segundo do mencionado artigo), constituindo um desestímulo ao oferecimento de impugnação dessas decisões, poderá ocorrer com maior frequência o trânsito em julgado dessas decisões monocráticas.

\footnotetext{
${ }^{232}$ Correspondente ao art. 467 do CPC.

${ }^{233}$ Equivalente ao art. 472 do CPC.

${ }^{234}$ Vide a respeito, Capítulo III.3, parte 3, deste trabalho.

${ }^{235}$ Após a aprovação pelo Senado, o artigo 884 do anteprojeto passou a ser o artigo 919.

${ }^{236}$ Que corresponde ao art. 485 do CPC.

${ }^{237}$ Que passou a ser o art. 888 após o trâmite no Senado e cuja redação é a seguinte: “Art. Incumbe ao relator: [...] III - negar seguimento a recurso inadmissível, prejudicado ou que não tenha atacado especificamente os fundamentos da decisão ou sentença recorrida; IV - negar provimento a recurso que contrariar: [...]; V dar provimento ao recurso se a decisão recorrida contrariar: [...]"
} 
Quanto aos incisos do artigo 884, destacamos as mudanças de maior relevo. Já no inciso II, o anteprojeto havia excluído das hipóteses de ação rescisória, as decisões finais proferidas por juízes absolutamente incompetentes. Porém, ao ser aprovado pelo Plenário do Senado, este inciso sofreu alteração, mantendo a hipótese de rescisória por decisão dada por juiz absolutamente incompetente. De qualquer sorte, ainda que fosse mantida a redação originária, possivelmente o julgamento por algum órgão absolutamente incompetente afrontaria alguma norma constitucional a respeito (v.g. art. 109 ou 114 que dispõem sobre a competência da justiça federal e trabalhista, respectivamente). Assim, se é possível o manejo da ação rescisória por violação à lei federal, muito mais razão haverá para se propor ação rescisória contra julgado que contrarie dispositivo constitucional e, por se tratar de nulidade absoluta, não passível de preclusão, nem sujeita à "sanatória geral" 238 da coisa julgada, passando o vício a ser motivo de rescisão, após o trânsito em julgado, desde que preenchidos os demais requisitos.

Alterou-se a redação do inciso V (atualmente, violar literal disposição de lei) que passou a ser: [a sentença ou o acórdão... podem ser rescindidos quando] "violarem manifestamente a norma jurídica", a qual se mostra mais adequada ao entendimento doutrinário e jurisprudencial, que preconizam que se deve dar um entendimento lato ao que se entende por lei, estando a redação sugerida em conformidade com o entendimento mais amplo que se deve atribuir ao texto legal.

Foi suprimida, no anteprojeto, a possibilidade de rescisão "quando houver fundamento para invalidar confissão, desistência ou transação, em que se baseou a sentença", pois, como já adiantado na exposição de motivos, a alteração visa conferir maior clareza na distinção entre o uso da ação rescisória e da ação de anulação, sendo tais vícios suscetíveis de impugnação via ação anulatória 239 .

Especificamente no que tange ao erro de fato para a ação rescisória, o anteprojeto corrige falha de redação do vigente inciso IX, do artigo 485 do Código de Processo Civil, que é transcrição (incorreta, como adiante se verá) do $\operatorname{artigo~} 395, \mathrm{n}^{\circ} 4$, do

\footnotetext{
${ }^{238}$ Vide Capítulo II, da parte 2, do presente estudo.

${ }^{239}$ "Art. 894. Os atos de disposição de direitos, praticados pelas partes ou por outros participantes do processo e homologados pelo juízo estão sujeitos à anulação, nos termos da lei. Parágrafo único: São anuláveis também atos homologatórios praticados no curso do processo de execução" (art. 929 após a aprovação pelo Senado).
} 
"Codice di Procedura Civile" italiano 240 , tendo o anteprojeto procedido às adequações de redação para melhor compreensão do texto, que passou a ter a seguinte redação:

“Art. 884: A sentença ou o acórdão de mérito, transitados em julgado, podem ser rescindidos quando:

$[\ldots]$

VIII - fundada em erro de fato verificável do exame dos autos.

Parágrafo único. Há erro quando a decisão rescindenda admitir um fato inexistente ou quando considerar inexistente um fato efetivamente ocorrido, sendo indispensável, num como noutro caso, que não tenha havido controvérsia, nem pronunciamento judicial sobre o fato." 241

A nova redação se mantém mais fiel ao artigo 395 do "Codice di Procedura Civile" italiano, que serviu de inspiração para a nossa ação rescisória por erro de fato, pois, o legislador de 1.973, quando da tradução do original italiano, equivocou-se ao traduzir a expressão "atti", que tanto pode significar atos ou autos, porém, no texto original italiano, "atti" está empregado por autos e não atos, como equivocadamente constou no texto de $1.973^{242}$. Finalmente, no anteprojeto adotou-se uma redação mais concisa, agrupando os dois parágrafos atinentes ao atual inciso IX, num parágrafo único.

Quanto ao processamento da ação rescisória, houve poucas alterações. A primeira delas consiste na explicitação de que as autarquias e fundações de direito público foram isentadas do depósito prévio da multa de cinco por cento 243 , bem como a isenção conferida no benefício da gratuidade da justiça, alcança o depósito em questão ( $\$ 1$ do art. 886) -, o que já estava pacificado em sede doutrinária e jurisprudencial 244.

240Consoante BARBOSA MOREIRA, José Carlos. Comentários ao Código de Processo Civil, cit., n. 5, p. 146.

241Lembrando que, após a aprovação pelo Senado, o art. 884 do anteprojeto passou a ser art. 919.

${ }^{242}$ Ver a respeito, BARBOSA MOREIRA, José Carlos Comentários ao Código de Processo Civil, cit., n. 85, p. 146 e ss.

Nesse aspecto, o art. 24-A, da Lei n ${ }^{\circ}$ 9028/95, já isentava as autarquias e Fundações da União, bem como o FGTS e a pessoa jurídica que o representa (parágrafo único) do recolhimento da multa em tela. A Súmula 175 do STJ também já dispensava o INSS do referido recolhimento.

${ }^{244}$ Conforme julgamento proferido na $\mathrm{AR} \mathrm{n}^{\mathrm{o}} 3828 / \mathrm{SP}$, relatada pelo Ministro Felix Fisher, publicado no DJe 07/05/10. 
O parágrafo segundo do artigo 886 deixa explícita a possibilidade de rejeição liminar da demanda rescisória, com base no artigo 317245 . Há recomendação para que a escolha do relator e do revisor da ação rescisória recaia, sempre que possível, em juiz que não haja participado do julgamento rescindendo 246 , preocupação que se mostra louvável, pois nem sempre o juiz que participou do julgamento a ser rescindido terá isenção suficiente para analisar a ação rescisória de seu julgado.

Finalmente, o artigo 893 (artigo 928 após o trâmite no Senado) reduz o prazo decadencial da ação rescisória para um ano, contado do trânsito em julgado, à exceção das ações rescisórias fundadas em prevaricação, concussão e corrupção do juiz e fundadas em prova falsa, quando o prazo decadencial se iniciará do trânsito em julgado da sentença penal que assim definir. Essa alteração não nos parece adequada, pois o método utilizado para coibir abusos é a previsão do depósito prévio da multa, e a redução do prazo não contribuirá para o aperfeiçoamento do sistema, ao qual também interessa o expurgo de vícios indesejáveis. A mudança vai de encontro às necessidades da ciência processual, que acabou por desenvolver a teoria da "relativização da coisa julgada" justamente para contornar casos em que a gravidade do vício existente no caso julgado era inaceitável, porém, os prazos para a ação rescisória já havia se escoado.

Ao menos, dever-se-ia ter incluído na exceção quanto ao início do prazo, a hipótese de obtenção de documento novo, de forma a minimizar a utilização da teoria da “desconsideração", prevendo o sistema um mecanismo mais eficiente para tais casos.

\footnotetext{
${ }^{245}$ "Art. 317. Independentemente de citação do réu, o juiz rejeitará liminarmente a demanda se: I manifestamente improcedente o pedido, desde que a decisão proferida não contrarie entendimento do Supremo Tribunal Federal ou do Superior Tribunal de Justiça, sumulado ou adotado em julgamento de casos repetitivos; II - o pedido contrariar entendimento do Supremo Tribunal Federal ou do Superior Tribunal de Justiça, sumulado ou adotado em julgamento de casos repetitivos; III - verificar, desde logo, a decadência ou prescrição; [...]".

${ }^{246}$ Atualmente, a matéria é regulada, de um modo geral, pelos regimentos internos dos tribunais, contendo restrições semelhantes: art. $67, \S 8^{\circ}$, do RISTF, arts. 78 e 79 do RISTJ e arts. 233 a 236 do RITJSP.
} 
D - PARTE QUARTA 


\section{O ERRO COMO FUNDAMENTO DA AÇÃO RESCISÓRIA}

\section{I.1. Introdução}

Inicialmente, cumpre-nos fazer algumas considerações sobre o erro, na forma como é tratado pelo direito material (civil) a fim de identificarmos se há pontos de convergência ou de divergência entre o erro como fundamento para a ação rescisória e o erro no direito civil e, caso positivo, em que medida.

O erro, no direito civil, quando substancial, é motivo de anulação do negócio jurídico, por defeituoso (Código Civil, art. 138). Porém, a disciplina de nulidades e de defeitos do direito material, não se aplica à ciência processual, pois esta difere neste aspecto, tendo em vista que, no direito processual, há a participação do Estado-juiz, que impõe, de modo imperativo, as suas decisões às partes, as quais devem sujeitar-se às mesmas, o que não ocorre no direito material, em que ambas as partes encontram-se em situação de igualdade em relação à celebração do negócio.

Tanto é assim que, nos negócios entre particulares, a vontade das partes é que conta para sua formação 247 , o que não se dá em relação aos atos do Poder Judiciário, justamente por emanarem de um órgão estatal, no exercício de uma função e poder 248 , impondo sua vontade às partes na relação jurídica processual.

A noção de erro no direito substancial aplicada ao negócio jurídico, inspirou-se basicamente na teoria da vontade, levando em consideração, antes de mais nada, a vontade do declarante e, em respeito a ela é que a se concebeu a anulação do ato quando esta estiver eivada por erro 249 .

\footnotetext{
${ }^{247}$ Ver a respeito, Sílvio S. Venosa, in Direito civil: parte geral. São Paulo: Atlas, 2007. v. 1, p. 365: “A vontade é a mola propulsora dos atos e dos negócios jurídicos. Essa vontade deve ser manifestada de forma idônea para que o ato tenha vida normal na atividade jurídica e no universo negocial. Se essa vontade não corresponder ao desejo do agente, o negócio jurídico torna-se suscetível de nulidade ou anulação."

${ }^{248}$ Conforme ensina Dinamarco, jurisdição é a "função exercida pelo Estado através de agentes adequados (os juízes), com vista à solução imperativa de conflitos interindividuais ou supra-individuais e aos demais escopos do sistema processual." (DINAMARCO, Cândido Rangel. Instituições de direito processual civil. 2. ed. São Paulo: Malheiros Ed., 2002. v. 1, n. 117, p. 309). Esclarece, ainda, que a característica da imperatividade se deve à presença do poder estatal (p. 310), existindo uma relação de autoridade e sujeição entre o Estado e os particulares, no exercício da jurisdição (p. 312).

${ }^{249}$ RODRIGUES, Silvio. Dos vícios do consentimento. São Paulo: Saraiva, 1979. p. 55.
} 
A primeira ressalva que se faz é que o erro, segundo o direito material, constitui um dos mais importantes vícios do consentimento na realização de negócio jurídico, tornando-o anulável250. Já, segundo os termos do artigo 485 caput e inciso IX, do Código de Processo Civil, para que haja a rescisão por erro, é necessário que a sentença tenha sido fundada em erro de fato. Assim, o erro que fundamenta a ação rescisória, é aquele que provém do órgão prolator da decisão rescindenda, e não das partes. Portanto, não se pode falar de vício do consentimento, pois não há que se falar em "consentimento" na prolação de decisão judicial, pois esta não depende da vontade, propriamente dita, de seu "agente" 251 .

O consentimento, segundo o direito material, é o reflexo da manifestação volitiva $^{252}$ e, quando este está inquinado de algum vício que o macula, tornando o ato defeituoso, a lei substancial permite a anulação do ato, a fim de proteger quem o manifestou 253 . Aí reside a segunda divergência entre a regulamentação do erro no direito substancial e aquela permitida para a ação rescisória, posto que a alegação do erro para a ação rescisória não se dá em favor do prolator da decisão eivada de erro, no caso, o órgão judiciário, mas da parte prejudicada por aquela decisão. No entanto, não se deve descartar a semelhança existente no fato de que o erro, se efetivamente verificado, nas duas situações, aproveita a quem o alega, ao menos em princípio.

O erro, no direito material, é conceituado pela doutrina como a falsa noção que alguém tem da realidade, ou ainda, a "compreensão psíquica errônea da realidade, ou seja, a incorreta interpretação de um fato"254. A própria lei processual, por seu turno, já se adiantou em definir no que consistiria o erro de fato que pode fundamentar a ação rescisória, nos seguintes termos: "há erro quando a sentença admitir um fato inexistente, ou quando considerar inexistente um fato efetivamente ocorrido." (Código de Processo Civil, artigo 485, IX, $\left.\S 1^{\circ}\right)$. Nesse aspecto, verifica-se que há convergência entre os conceitos confrontados, pois ambos representam a falsa concepção da realidade, ou seja, dos fatos.

\footnotetext{
${ }^{250}$ Art. 138 do CC.

${ }^{251}$ Como observado, a sentença não é um ato de consentimento mas do modo como o juiz sente a causa (vide tópico I.2.7 na parte 3).

${ }^{252}$ Neste sentido, RODRIGUES, Silvio. Dos vícios do consentimento, cit., p. 10.

${ }^{253}$ RODRIGUES, Silvio. Dos vícios do consentimento, cit., p. 10.

${ }^{254}$ VENOSA, Sílvio de Salvo. Direito civil: parte geral, cit., p. 368.
} 
Quanto ao erro de direito, pode-se dizer que este está inserido no inciso V, do artigo 485 do Código de Processo Civil, que vem definido como violação à literal disposição de lei. No caso, pode configurar como erro de direito a incorreta aplicação da lei, mas não sua má interpretação (como se verá adiante). De qualquer forma, o direito material também considera o erro de direito como passível de viciar o negócio jurídico, desde que não implique recusa na aplicação da lei (inciso III, do artigo 139, do Código Civil).

O direito substancial diferencia, outrossim, o erro da ignorância. Enquanto o erro é a noção equivocada dos fatos, a ignorância é o seu total desconhecimento 255 , informando a doutrina que as duas figuras, ontologicamente, não se confundem, porém, ressalva que, juridicamente a distinção é irrelevante, pois pouco importa se o ato é defeituoso pelo conhecimento equivocado da realidade ou se por seu total desconhecimento dela 256 .

No campo do direito processual, também surge essa diferença e, igualmente, na lei processual, pouco importa se a sentença foi dada por desconhecimento total de um fato ou somente de com base em entendimento de forma equivocada sobre esse fato, desde que a sentença admita um fato inexistente (noção equivocada dos fatos, tal como no erro) ou considere inexistente fato efetivamente ocorrido (como no caso de ignorância, ou seja, a sentença ignora a ocorrência de determinado fato). Qualquer das hipóteses é suficiente para a revisão da decisão por ação rescisória.

A doutrina que examinou a questão do erro no direito substancial distingue, outrossim, o erro escusável do erro não escusável, havendo divergência quanto à real necessidade de o erro ser escusável para anular o ato, uma vez que a legislação substancial nada disse a esse respeito 257 . O erro não escusável seria o erro grosseiro, facilmente perceptível ao homem comum, de diligência normal. A maior parte da doutrina parece inclinar-se pela necessidade de o erro ser escusável para poder ser alegado de forma proveitosa, pois, do contrário, qualquer um que não agisse com a diligência e a prudência esperada para o negócio, ou que deixasse passar erro grosseiro, poderia requerer,

\footnotetext{
${ }^{255}$ "A ignorância é ausência de conhecimento, falta de noção a respeito de um assunto; não há na ignorância nem mesmo a representação imperfeita, porque inexiste qualquer representação mental ou conhecimento psíquico." (VENOSA, Sílvio de Salvo. Direito civil: parte geral, cit., n. 22.2, p. 376).

256Ver a respeito, PEREIRA, Caio Mário da Silva. Instituições de direito civil. rev. e atual. por Maria Celina Bodin de Moraes. Rio de Janeiro: Forense, 2006. v. 1, p. 517.

${ }^{257}$ Neste sentido, RODRIGUES, Silvio. Dos vícios do consentimento, cit., p. 59 e ss.
} 
posteriormente, a nulidade do ato, com base no erro, em prejuízo do contratante de boa-fé. Assim, o erro que permite a anulação do negócio jurídico deve ser escusável ${ }^{258}$, o que ocorre quando o erro não provém de "extraordinária ignorância"259. Porém, com promulgação do novo Código Civil, o que se põe em relevo para a anulação pelo erro, é a diligência empregada na consecução do negócio, deixando-se a escusabilidade para segundo plano 260 .

Tais considerações, por certo, não se aplicam ao erro na ação rescisória, por ser este proveniente de um ato judicial e não um ato negocial, em que o negócio é celebrado no interesse das partes contratantes. A decisão judicial é proferida por terceiro, no caso, o Estado-juiz, imparcial ao quanto decidido, e espera que este empregue sempre a diligência necessária ao proferir suas decisões, não se podendo falar em falta de diligência, até porque, ainda que esta fique apurada, não é em benefício próprio que o Estado-juiz profere suas decisões e, eventual falta de diligência na execução de suas tarefas, irá prejudicar as partes envolvidas no litígio e não aquele que praticou o ato sem se valer da diligência esperada (em última análise, o próprio Estado), não sendo relevante, portanto, tratar-se de erro escusável ou não 261 .

Resta, ainda, analisar as hipóteses legais da incidência do erro regida pela legislação material para verificar sua eventual aplicabilidade ao direito processual. A lei material prevê que o erro que permite a anulação do negócio jurídico é o erro substancial e nos incisos do artigo 139 do Código Civil enumera as hipóteses de sua ocorrência. Em contrapartida, o artigo 142 da legislação material determina que o erro de identificação quanto à indicação da pessoa ou da coisa a que se referir a declaração de vontade, não viciará o negócio entabulado, quando estes forem identificáveis, por tratar-se de erro acidental ou incidental.

Assim, o direito material exige, para que se possa anular o ato, que o erro seja substancial ou essencial. Erro essencial é "o que tem papel decisivo na determinação da vontade do declarante, de modo que, se conhecesse o verdadeiro estado de coisas, não

\footnotetext{
${ }^{258}$ Ver a respeito: RODRIGUES, Silvio. Dos vícios do consentimento, cit., p. 62 e ss., e VENOSA, Sílvio de Salvo. Direito civil: parte geral, cit., p. 370 e ss.

${ }^{259}$ VENOSA, Sílvio de Salvo. Direito civil: parte geral, cit., p. 371.

${ }^{260}$ Neste sentido, VENOSA, Sílvio de Salvo. Direito civil: parte geral, cit., p. 371.

${ }^{261}$ Não se poderia tolher da parte prejudicada o direito à ação rescisória se o juiz não tivesse adotado as mínimas diligências necessária na realização de seu ofício.
} 
teria desejado, de modo nenhum, concluir o negócio."262. Ao erro essencial contrapõe-se o erro acidental ou incidental, que não se mostra suficiente para anular o negócio e recai sobre os motivos ou as qualidades secundárias do negócio.

Como no caso do erro para a rescisão da sentença não há que se falar em declaração de vontade, não se aplica nenhuma das hipóteses enumeradas nos inciso do artigo 139 do Código Civil ao erro de fato descrito na norma processual apto a ensejar a rescisão da sentença.

Finalmente, o disposto no artigo 144 do Código Civil determina que o erro não prejudica a validade do negócio quando a parte a quem se dirige se compromete a executálo de acordo com a vontade real do manifestante. Também não se cogita da aplicação dessa regra ao ato judicial, pois não há acordo de vontades nas decisões judiciais, mas a imposição da vontade concreta da lei ao caso examinado.

Constata-se, portanto, que a sistemática do erro no Código Civil não pode ser totalmente transportada para o direito processual, mais especificamente para o erro de fato como fundamento para a ação rescisória, por se tratar de situações completamente diversas, especialmente tendo em vista que, o erro na legislação material cuida da hipótese do erro aplicável ao negócio jurídico, travado notadamente entre particulares, sendo que o negócio somente se concretiza pela vontade das partes, enquanto que o erro da legislação processual ora em análise, refere-se ao erro incidente no ato judicial, praticado pelo Estado-juiz, no exercício da função e do poder jurisdicional, dotado de imperatividade, sujeitando as partes ao referido ato, não se cogitando da existência (e, portanto, validade) da vontade das partes, mas somente da vontade concreta da lei ao caso em exame, aplicada de forma imperativa e vinculante às partes envolvidas no litígio. Aproveitam-se somente os conceitos estabelecidos pela legislação material.

A respeito do tema, Salvatore Satta possui interessante posicionamento. Partindo claramente do conceito de sentença desenvolvido por Chiovenda ${ }^{263}$, o autor afirma que a "revocazione" italiana 264 possui como caráter distintivo em relação aos

\footnotetext{
${ }^{262}$ VENOSA, Sílvio de Salvo. Direito civil: parte geral, cit., p. 372.

${ }^{263}$ Como sendo "a provisão do juiz que, recebendo ou rejeitando a demanda do autor, afirma a existência ou a inexistência de uma vontade concreta de lei que lhe garanta um bem ou respectivamente a inexistência ou existência de uma vontade de lei que garanta um bem ao réu." (CHIOVENDA, Giuseppe. Instituições de direito processual civil. Tradução da 2. ed., por Paolo Capitano. Campinas: Bookseller, 2000. v. 1, p. 198).

${ }^{264} \mathrm{Na}$ qual o legislador pátrio se inspirou para incluir a ação rescisória por erro de fato, conforme adiante se verá.
} 
outros meios de impugnação, o fato de haver um "vício de vontade" no pronunciamento judicial, esclarecendo, ainda, que esse vício de vontade não exprime tanto uma vontade do juiz, que possa ser comparável à vontade do particular existente na formação do negócio jurídico, mas diz respeito à "vontade da norma", que é materializada por meio do pronunciamento judicial e conclui que, a "revocazione" não é senão um meio de impugnação através do qual se faz valer um especial motivo de anulação da sentença, qual seja, o vício de vontade do juiz 265266.

Continuando sua exposição, Satta observa que os motivos que dão azo ao vício da vontade do juiz são os motivos elencados como fundamentos para a "revocazione"267, distintos, portanto, dos motivos da lei material.

\section{I.2. Exame da justiça das decisões}

O anterior Código de Processo Civil prescrevia que a injustiça da sentença e a má apreciação da prova ou errônea interpretação do contrato não autorizavam o exercício da ação rescisória 268 , orientação que, embora não constasse do Código de Processo Civil em vigor, acabou acolhida pela doutrina 269 e pela jurisprudência 270 atual. Com efeito, tanto a doutrina como a jurisprudência atual repetem a regra da impossibilidade de exame da justiça da decisão, pela ação rescisória, o que não deixa de ser um paradoxo, pois como anteriormente ressaltado 271 , o escopo da ação rescisória é justamente o de resguardar o valor da justiça das decisões em detrimento do valor segurança.

No âmbito da doutrina italiana admite-se que a ação rescisória possa cumprir a função de eliminação de injustiça nas decisões revistas.

\footnotetext{
${ }^{265}$ In SATTA, Salvatore. Diritto processuale civile, cit., p. 355.

${ }^{266}$ Ao discorrer sobre a competência para a "revocazione", que na Itália, diferentemente da nossa ação rescisória, é sempre do juiz que proferiu a sentença impugnada, Satta esclarece que assim deve ser, pois não se trata propriamente de corrigir um erro, mas de reparar um juízo que não pode ser mantido, em razão do vício da vontade do juiz (SATTA, Salvatore. Diritto processuale civile, cit., p. 360 e ss.).

${ }^{267}$ SATTA, Salvatore. Diritto processuale civile, cit., p. 356.

${ }^{268}$ Art. 800 do CPC/39.

${ }^{269}$ Neste sentido, afirmando que a norma subsiste "implícita”, BARBOSA MOREIRA, José Carlos. Comentários ao Código de Processo Civil, cit., p. 147.

${ }^{270}$ V.g., STJ, AgRg na AR 4325/PR, rel. Min. Luiz Fux, DJe 25/11/09.

${ }^{271}$ Vide capítulo II.1, parte 2.
} 
Com efeito, Chiovenda, discorrendo sobre a diferença entre a "revocazione" e o "recurso per cassazione", afirma: "Assim, a demanda de revogação é restrita a determinadas causas de injustiça de fato da sentença (arts. 494 e segs.); e o recurso de cassação só é cabível quanto aos erros sobre a questão de direito da sentença e quanto às nulidades (arts. 517 e segs.)"272. Também C. Mandrioli certifica o caráter de preservação da justiça ao se permitir a revisão do provimento impugnado via "revocazione"273. Calamandrei, cita, ainda, a hipótese específica de "revocazione" por erro de fato como uma exceção ao princípio segundo o qual a validade da sentença passada em julgado não depende da sua justiça 274 . Satta também ressalta que o vício atacado pela "revocazione" é elemento sintomático da injustiça 275 .

$\mathrm{Na}$ doutrina nacional, o professor Dinamarco também já ressaltou a íntima ligação existente entre a ação rescisória e a preservação do valor justiça, não obstante o caráter extraordinário do instituto, que tem por último escopo o aprimoramento da justiça no caso concreto 276 .

Tendo em vista a inexistência de prescrição legal no sentido da impossibilidade da revisão da justiça das decisões por meio da ação rescisória, não há razão para se excluir, a priori, a revisão da justiça das decisões por meio da ação rescisória, tendo em vista que, em última análise, uma sentença que contenha os vícios do artigo 485 do Código de

CHIOVENDA, Giuseppe. Instituições de direito processual civil, cit., v. 1, p. 201.

${ }^{273}$ "La revocazione è in sostanza un'impugnzione a critica vincolata, ma che, tuttavia, in quanto investe il giudizio di fatto sulla base di motivi che solo eccezionalmente implicano una nullità, coinvolge la giustizia e non (almeno direttamente) la legalità del provvedimento impugnato." (MANDRIOLI, Crisanto. Corso di diritto processuale civile: il processo di cognizione, cit., v. 2, p. 298).

${ }^{274}$ Vale destacar as palavras do mestre a respeito do tema: "Questo speciale caso di revocazione, ch non si può neppure considerare come un caso di vera actio nullitatis, perchè il difetto che ne costituisce la causa non ha la natura di un error in procedendo, è un dei più caratteristici esempi di quella annulabilità per difetto di giudizio che talora le legislazioni ammettono come eccezione al principio secondo il quale la validità della sentenza passata in diudicato non dipende della sua giustizia." (CALAMANDREI, Piero. La cassazione civile. Torino: Fratelli Bocca: Italian Book Co., 1920. p. 226 e ss.).

${ }^{275}$ SATTA, Salvatore. Diritto processuale civile, cit., p. 355.

${ }^{276}$ Vale transcrever as lúcidas palavras do professor das arcadas: "Não comungo da idéia de que ação rescisória, recurso especial e recurso extraordinário fossem institutos voltados exclusivamente à estabilidade da ordem jurídico-positiva e outros escopos de ordem pública, sem guardar relação com as aspirações dos sujeitos em conflito ou com o valor do justo. [...]. Diante disso e a ninguém sendo lícito ignorar o caráter extraordinário dos institutos da ação rescisória e daqueles recursos, o que proponho é o trato de todos eles pelo duplo aspecto de seu valor perante a ordem pública e da utilidade como modo de aprimoramento da justiça em casos concretos. A estabilidade dos julgados, prestigiada pela garantia da auctoritas rei judicatae, tem seu inegável valor mas o valor que ela tem não é maior que o da necessidade de fazer justiça." (DINAMARCO, Cândido Rangel. Fundamentos do processo civil moderno., cit., v. 2, p. 999 e ss., g.n.). 
Processo Civil não deixa de ser uma sentença injusta 277 . O que não se permite por meio da ação rescisória é a revisão das questões de fato debatidas e resolvidas na decisão rescindenda, por ocasião do ius rescissorium, ou seja, a impossível a reapreciação dos fatos, a não ser nos casos expressamente autorizados em lei 278 .

\section{I.3. Erro de fato}

\section{I.3.1. Origem}

Como é notório, o legislador pátrio se inspirou no "Codice di Procedura Civile" italiano para introduzir o erro de fato como causa de pedir para a ação rescisória no inciso IX, do artigo 485 do Código de Processo Civil, pois, como se verifica na redação do citado dispositivo, ele é quase que uma transposição literal do "articolo 395, n 4" italiano, que possui a seguinte redação:

“Art. 395

\section{(Casi di Revocazione)}

Le sentenze pronunciate in grado di appello o in unico grado possono essere impugnate per revocazione:

\section{$[\ldots]$}

4) se la sentenza è l'effetto di un errore di fatto risultante dagli atti o documenti della causa. Vi e' questo errore quando la decisione è fondata sulla supposizione di un fatto la cui veritá è incontrastabilmente esclusa, oppure quando è supposta l'inesistenza di un fatto la cui veritá è positivamente stabilita, e tanto nell'uno quanto nell'altro caso se il fatto non costitui' un punto controverso sul quale la sentenza ebbe a pronunciare;"

Como já adiantado, ao proceder à tradução do referido texto legal, o legislador pátrio cometeu um equívoco, pois a expressão "atti", que tanto pode significar atos ou

\footnotetext{
${ }^{277}$ Não está aqui a se defender simplesmente a total revisão das decisões por meio da ação rescisória, que só é possível nos estritos casos previamente estabelecidos pelo legislador no art. 485 do CPC, mas o que se pretende é que não se furte de analisar determinado vício eventualmente constante em uma decisão, por meio de ação rescisória, simplesmente sob alegação de não ser viável a verificação da "justiça da decisão". ${ }^{278}$ Assim, por exemplo, reapreciação do conjunto probatório, com exclusão da prova falsa, no caso do inciso VI, do art. 485, CPC, ou ainda, considerar o fato tido por inexistente, mas que já estava provado, no caso no inciso IX, do mesmo artigo.
} 
autos, no texto original (italiano) está por autos, porém, ao proceder a tradução, o legislador acabou por incluir o termo atos, o que subtraiu um pouco do sentido da redação final da norma nacional 279 .

\section{I.3.2. Pressupostos}

O vício que pode fundamentar a rescisória, nessa hipótese específica do erro de fato, tem necessariamente que fazer parte da sentença, pois assim determina o inciso IX do artigo 485 do Código de Processo Civil e, tanto pode ter havido erro que permite utilização da via rescisória, quando a sentença afirma entender ter havido certo fato que não houve, ou de ter ignorado a ocorrência de fato que efetivamente se constatou ter havido.

Como bem observado pela doutrina e acima mencionado, a disciplina do erro de fato para a ação rescisória encontra suas raízes no direito italiano, sendo legítimo valermo-nos dos ensinamentos doutrinários e entendimentos jurisprudenciais daquele país para elucidação das mais variadas questões que podem surgir com respeito ao instituto em estudo, mas não sem ressalvas, pois os sistemas processuais italiano e brasileiro possuem vários pontos divergentes, conforme advertido por Sydney Sanches 280 , não sendo oportuno simplesmente "importar" as soluções encontradas na península, pois, muitas vezes se mostram inadequadas ao nosso ordenamento e cultura jurídica.

\section{a) caracterização}

Para que se abra a via da rescisória com fundamento no erro de fato (inciso IX), antes de tudo é preciso que o erro seja cometido pelo órgão do poder judiciário, não se podendo alegar erro da parte para viabilizar a rescisória 281 , o que decorre dos próprios termos da lei, pois a sentença é que deve se fundar em erro de fato. E mais, é preciso que o

\footnotetext{
${ }^{279}$ Ver a respeito, BARBOSA MOREIRA, José Carlos. Comentários ao Código de Processo Civil, cit., n. 85, p. 146, que aponta, também, a insurreição na tradução do termo "risultante", que no texto italiano significa "que transparece, que emerge, que ressalta". Assim, a tradução mais correta seria: "[...] é efeito de erro de fato que transparece dos autos ou documentos da causa".

${ }^{280}$ In SANCHES, Sydney. Ação rescisória por erro de fato. Revista de Processo, São Paulo, ano 11, n. 44, p. 65, out./dez. 1986.

${ }^{281}$ Neste sentido: ALESSIO, Giovanni. La revocazione delle sentenze civili, cit., p. 77
} 
erro recaia sobre um fato, ou seja, é necessário que o erro se dê sobre a ocorrência ou não do fato em si.

Muito controvertida é a doutrina italiana sobre a conceituação do erro de fato que pode embasar a "revocazione"282. Segundo pondera Chiovenda, este consiste num erro relativo a um fato considerado pelo juiz, "mais ou menos irrefletidamente", não se podendo assim considerar um "simples erro dos sentidos", tendo em vista que se trata de um "defeito de reflexão e, consequentemente, do raciocínio"283. Calamandrei, por sua vez, reputa haver erro de fato quando há um defeito de percepção ou de reflexão 284 .

Andrioli, recorrendo a vários autores, ressalta a opinião contrastante de cada um: conforme D'Onofrio, trata-se não de uma falsa expressão, mas de um pensamento inexato, por um falso pressuposto, sendo determinado por defeito de reflexão e não por erro de sentidos; esclarece que, na opinião de Satta, a falsa representação da realidade é provocada não por um erro de juízo, mas por um erro dos sentidos 285 ; ressalta que, Liebman fala em insuficiente reflexão ou desatenção do juiz; e que Redenti, mais realista, fala em engano grosseiro ou mero equívoco do juiz na leitura dos autos da causa. E conclui: se o erro, concebido como falsa representação de um objeto, pressupõe um contraste entre duas representações divergentes do mesmo objeto, e exige-se um critério através do qual deve prevalecer uma representação sobre a outra e, no caso do erro de fato para a "revocazione", e uma representação emerge da sentença e outra dos autos e documentos do caso, normalmente a primeira deve prevalecer, mas há uma inversão se a primeira representação é fruto de uma "suposição" e não de juízo e a segunda representação emerge de forma irrefutável e não é objeto de controvérsia 286.

Colesanti define o erro de fato por exclusão, afirmando que não estão compreendidos no erro de fato, o erro de direito, bem como o erro no juízo de fato derivado de uma violação de uma norma jurídica (por exemplo, de índole probatória) e o erro material 287 . De outra parte, a jurisprudência italiana considera que o erro de fato

\footnotetext{
${ }^{282}$ Vittorio Colesanti enfatiza que, a respeito do tema, "Pochi, invero, sono i punti incontroversi [...]." (COLESANTI, Vittorio. Sentenza civile (revocazione della), cit., p. 1168).

${ }^{283}$ CHIOVENDA, Giuseppe. Instituições de direito processual civil, cit., v. 1, p. 277 e ss.

${ }_{285}^{284}$ CALAMANDREI, Piero. La cassazione civile, cit., p. 226.

${ }^{285}$ Satta enfatiza, ainda, que mesmo os fatos notórios podem ser motivo de "revocazione", dentro dos limites que poderiam ser conhecidos a seu tempo (SATTA, Salvatore. Diritto processuale civile, cit., p. 358).

${ }^{286}$ ANDRIOLI, Virgilio. Commento al codice di procedura civile. Napoli: E. Jovene, 1960. v. 2, p. 395.

${ }^{287}$ COLESANTI, Vittorio. Sentenza civile (revocazione della), cit., p. 1168.
} 
consiste num erro de percepção ou num mero engano material que tenha induzido o juiz a supor a existência de um fato inexistente ou considerar inexistente um fato efetivamente ocorrido, verificável na comparação dos autos e documentos da causa 288 .

Parece-nos mais acertado o entendimento de que o erro de fato se caracteriza pela desatenção do juiz no exame e leitura dos autos, não estando compreendido no erro de fato, obviamente, o erro de direito, nem o erro material, o equívoco na qualificação jurídica dos fatos ${ }^{289}$, bem como a errônea interpretação ou valoração da prova ${ }^{290}$, ou seja, tudo aquilo que, no âmbito do mérito do processo, é deixado à valoração discricionária do juiz 291 .

Para distinguir o erro material do erro de fato, Chiovenda afirma que, este último, diversamente do erro de fato, não trata de um erro dos sentidos, mas se refere somente à manifestação "exterior" da vontade do juiz. Como bem observam Frederico Carpi e Michele Tarufo, o erro de fato distingue-se do erro material, na medida em que este emerge do próprio texto da sentença, havendo, portanto, fundamento textual, enquanto que, para verificação do erro de fato, se faz mister o exame dos autos ou documentos da causa, possuindo, assim, fundamento fora do texto da sentença 292 .

\section{b) nexo de causalidade}

A doutrina italiana é mais pacífica no que se refere ao pressuposto no nexo de causalidade entre o erro de fato e a decisão para a "revocazione". Com efeito, para que seja viável a "revocazione" por erro de fato, é necessário que exista uma relação de causalidade entre o erro e o provimento, ou seja, este deve ser essencial ou decisivo para a decisão adotada, no sentido de que, se eliminado o erro, cai por terra o pressuposto no qual se

${ }^{288}$ CARPI, Federico; TARUFFO, Michele. Commentario breve al codice di procedura civile. Padova: Cedam, 2002. p. 1172.

${ }^{289}$ Neste sentido, BARBOSA MOREIRA, José Carlos. Comentários ao Código de Processo Civil, cit., p. 148 .

${ }^{290}$ BARBOSA MOREIRA, José Carlos. Comentários ao Código de Processo Civil, cit., p. 152.

${ }^{291}$ Conforme MANDRIOLI, Crisanto. Corso di diritto processuale civile: il processo di cognizione, cit., p. 243.

${ }^{292}$ In CARPI, Federico; TARUFFO, Michele. Commentario breve al codice di procedura civile, cit., p. 1173. No mesmo sentido, PISANI, Andrea Proto. Lezioni di diritto processuale civile. Napoli: E. Jovene, 1999. p. 570. 
funda a decisão 293 . Tal entendimento implica que, existindo o nexo de causalidade direito entre a circunstância denunciada como motivo de "revocazione" e o conteúdo da decisão, não é permitido que se proceda a novo exame dos fatos para proferir a nova decisão 294 , pois a mudança no entendimento anteriormente firmado, é consequência direta da reparação do erro cometido.

A doutrina nacional também entende necessário que exista o nexo de causalidade entre o erro e a decisão para viabilizar a ação rescisória por erro de fato, declarando ser imprescindível que o erro seja determinante para a conclusão contida no mérito da sentença rescindenda 295.

\section{c) erro aparente}

Outro requisito para a configuração do erro de fato como causa de revogação da sentença, é que o erro resulte de forma irrefutável dos documentos e autos do processo $^{296}$. O erro deve resultar, de modo muito claro, dos documentos dos autos, sendo, pois, evidente 297 . Assim, o erro de fato deve despontar imediatamente e resultar simples e diretamente dos autos, sem que para sua constatação seja necessário argumentação indutiva ou indagações hermenêuticas 298 .

Nesta seara, não se admite a produção de qualquer outra prova para demonstrar o erro ou para fazer valer as razões de seu interesse no juízo rescisório, pois o erro deve ser apurado de acordo com os elementos já existentes na demanda principal (caso houvesse a necessidade de se produzir novos documentos, não teria havido erro do juiz, que teria julgado conforme os documentos então existentes).

\footnotetext{
${ }^{293}$ Vide CARPI, Federico; TARUFFO, Michele. Commentario breve al codice di procedura civile, cit., p. 1171.

${ }^{294}$ Ver a respeito, COLESANTI, Vittorio. Sentenza civile (revocazione della), cit., p. 1168.

${ }^{295}$ De acordo com Flavio Yarshell, Tutela jurisdicional, cit., p. 339 e Barbosa Moreira, Comentários ao Código de Processo Civil, cit., p. 148. Sydney Sanches é textual ao afirmar: "é preciso que a sentença seja efeito do erro de fato; que haja entre aquela e este um nexo de causalidade." In Ação rescisória por erro de fato, cit., p. 57.

${ }^{296}$ A propósito, ANDRIOLI, Virgilio. Commento al codice di procedura civile, cit., p. 630.

${ }^{297}$ Consoante CALAMANDREI, Piero. La cassazione civile, cit., p. 226 e CARPI, Federico; TARUFFO, Michele. Commentario breve al codice di procedura civile, cit., p. 1171.

${ }^{298}$ V. CARPI, Federico; TARUFFO, Michele. Commentario breve al codice di procedura civile, cit., p. 1172.
} 
Neste mesmo sentido segue a doutrina nacional, conforme ensina Barbosa Moreira, um dos pressupostos para ação rescisória por erro de fato é "que o erro seja apurável mediante simples exame dos documentos e mais peças dos autos, não se admitindo de modo algum, na rescisória, a produção de quaisquer outras provas tendentes a demonstrar que não existia o fato admitido pelo juízo, ou que ocorrera o fato por ele considerado inexistente" 299 .

\section{d) fatos que podem ensejar a ação rescisória}

Há uma certa discussão na doutrina italiana acerca de quais fatos seriam passíveis de caracterizar o erro a fim de viabilizar a ação rescisória: somente os fatos de direito material, ou fatos "da vida", ou também os fatos que pertencem ao direito processual. Entendimento no sentido de que tanto pode ser um fato de direito substancial ou um elemento do procedimento, é manifestado por Comoglio, Ferri e Taruffo ${ }^{300}$. Em sentido contrário, afirmando que o fato sobre o qual incide o erro, deve ser externo ao processo, é o entendimento de Salvatore Satta ${ }^{301}$, posição que parece ser minoritária.

De qualquer modo, no âmbito da nossa doutrina parece não haver controvérsias a respeito, sendo possível a ação rescisória por erro de fato tanto referente ao direito material como ao direito processual, até porque não há na legislação qualquer restrição a esse respeito.

\section{e) ausência de controvérsia}

Para que o erro de fato seja hábil a permitir a "revocazione", é necessário que o fato sobre o qual recai o erro, não tenha constituído um ponto controverso na causa, sobre o qual a sentença tenha feito alguma apreciação 302 .

\footnotetext{
${ }^{299}$ In BARBOSA MOREIRA, José Carlos. Comentários ao Código de Processo Civil, cit., p. 148. No mesmo sentido, SANCHES, Sydney. Ação rescisória por erro de fato, cit., p. 57.

${ }^{300}$ In COMOGLIO, Luigi Paolo; FERRI, Corrado; TARUFFO, Michele. Lezioni sul processo civile, cit., p. 860, bem como por Carpi e Taruffo, "Commentario breve al codice di procedura civile, cit., p. 1172.

${ }^{301}$ Conforme mencionado por Colesanti, in Sentenza civile (revocazione della), cit., p. 1168.

${ }^{302}$ CARPI, Federico; TARUFFO, Michele. Commentario breve al codice di procedura civile, cit., p. 1172.
} 
Porém, nesse caso, não nos parece adequado simplesmente adotar a solução italiana, pois, como bem lembrado por Sydney Sanches, “[...] é preciso não se perder de vista que o sistema nacional pode não ser o mesmo, referentemente ao ônus de impugnação de afirmações contidas no processo", o que, conforme ressalta o autor, pode gerar grandes diferenças de tratamento 303 .

Mas não é só. Além de eventual diferença no sistema dos ônus de impugnação, no direito italiano existe a previsão de outro remédio para as hipóteses de pontos de fato "em que tenha havido controvérsia", que é o "ricorso per cassazione", como notado por Proto Pisani, que ressalta justamente a exigência de ausência de controvérsia feita para a "revocazione" "a differenza del punto di fatto di cui all'art. 360, n. 5" [ricorso per cassazione $]^{304}$, na qual não se exige a ausência de controvérsia.

Ademais, não nos parece lógico que, caso a parte tenha permanecido inerte (agindo até com desídia), possa valer-se da ação rescisória, enquanto que a outra que tenha sido mais combativa, atacando o ponto de fato (e não obstante tal controvérsia, o juiz, agindo de modo equivocado, tenha se mantido inerte) seja tolhida da possibilidade de ajuizar demanda rescisória, apesar do erro judicial existente. Demais disso, como se disse, o erro de fato é cometido pelo juiz, não pelas partes e, dessa forma, não pode assumir relevo a atitude das partes na verificação do erro de fato para a ação rescisória, pois se trata de ato exclusivamente do juiz. Seria impor à parte um prejuízo (vedando-lhe a utilização da ação rescisória para verificação de um erro de fato supostamente existente na sentença), por um equívoco a que não deu causa (pois dependente somente do ato do juiz que proferiu a decisão viciada).

Conclusão em sentido contrário, ou seja, vedando o uso da ação rescisória por erro quando houvesse controvérsia entre as partes, só poderia ser admitida, caso fosse disponibilizada à parte, outra ferramenta para defesa de seus direitos, tal como no direito italiano.

De qualquer forma, não parece ser apropriado suprimir da parte a possibilidade de propositura da ação rescisória por erro de fato, tão somente porque tenha havido controvérsia entre as partes em relação ao fato, especialmente se nada tiver ficado resolvido, a respeito da questão, na decisão rescindenda.

\footnotetext{
${ }^{303}$ SANCHES, Sydney. Ação rescisória por erro de fato, cit., p. 60.

${ }^{304}$ PISANI, Andrea Proto. Lezioni di diritto processuale civile, cit., p. 570.
} 
Solução que se afigura mais adequada, a fim de não contrariar a expressa determinação legal que impõe como requisito a ausência de controvérsia sobre o fato, parece ser no sentido de que, havendo controvérsia sobre determinado fato e, não tendo o juiz se pronunciado sobre o mesmo, então não terá havido mero erro de fato, mas erro de direito $^{305}$, o que eventualmente poderia ensejar a demanda rescisória por violação à literal disposição de lei 306 .

\section{f) ausência de pronunciamento judicial}

Ainda que não seja esse, na doutrina italiana, um dos aspectos mais controvertidos do instituto, no direito brasileiro é o ponto que mais suscita dúvidas na doutrina e nos operadores do direito.

Conforme noticia Sydney Sanches, a exigência da ausência de pronunciamento judicial sobre $o$ fato recebeu severas críticas da doutrina, valendo destacar, em especial, a dúvida suscitada por Luís Antônio de Andrade: “Como se irá atacar a sentença, dizendo que ela supôs um fato que na verdade não existiu, ou que considerou inexistente um fato que ocorreu, se sobre o fato a sentença não se pronunciou?"307 308.

A respeito do tema, é conhecida a opinião de Barbosa Moreira, segundo o qual $^{309}$ :

“o que precisa haver é incompatibilidade lógica entre a conclusão enunciada no dispositivo da sentença e a existência ou inexistência do fato, uma ou outra provada nos autos mas porventura não colhida pela percepção do juiz, que, ao decidir, pura e simplesmente saltou por sobre o ponto sem feri-lo. Se, ao contrário, o órgão judicial, errando na

${ }^{305}$ Uma vez que o juiz não teria resolvido uma questão de fato controvertida, como deveria a teor do artigo 458, II e III do CPC.

${ }^{306}$ Porém, acreditamos que nem sempre será possível alegar-se erro de direito, nos moldes previstos na lei. Poderíamos pensar, por exemplo, num litígio entre as partes envolvendo vários negócios jurídicos e vários contratos firmados entre as partes, sucessivos e que regulam as situações existentes entre as mesmas. Caso tenha havido um contrato posterior revogando total ou parcialmente as disposições de um outro contrato anterior e o juiz não tenha atentado para esse último contrato, julgando com base nas disposições revogadas do contrato anterior, só por ter havido controvérsia entre as partes, nos termos da lei, não se poderia alegar erro de fato para a ação rescisória, porém, tal fato não nos parece consistir, igualmente, em erro de direito, nos termos do inciso $\mathrm{V}$, do art. 485, do CPC.

${ }^{307}$ SANCHES, Sydney. Ação rescisória por erro de fato, cit., p. 60.

${ }^{308}$ No mesmo sentido foram as críticas à redação do texto legal, por ocasião da aprovação do Código de Processo Civil de 1973, conforme noticia Sydney Sanches (Ação rescisória por erro de fato, cit., p. 49 e ss).

${ }^{309}$ BARBOSA MOREIRA, José Carlos. Comentários ao Código de Processo Civil, cit., p. 151 e ss. 
apreciação da prova, disse que decidia como decidiu porque o fato ocorrera (apesar de provada nos autos a não ocorrência), ou porque o fato não ocorrera (apesar de provada a ocorrência), não se configura o caso do inciso IX. A sentença, conquanto injusta, não será rescindível.

O pensamento da lei é o de que só se justifica a abertura de via para a rescisão quando seja razoável presumir que, se houvesse atentado na prova, o juiz não teria julgado no sentido em que julgou."

Como se disse, a controvérsia parece inexistir no direito italiano e, tal se deve, em razão do modo diverso como a questão é enfrentada na península, ou por outro equívoco na tradução do texto original italiano, tão ou mais relevante que os anteriormente apontados.

No que tange à exigência de ausência de pronunciamento judicial, consta expressamente no texto legal italiano: "[...] se il fatto non constituì un punto controverso sul quale la sentenza ebbe a pronunciare." Ou seja, se o fato não constitui ponto controverso sobre o qual a sentença teve que se pronunciar. Portanto, a ausência de pronunciamento judicial, refere-se à controvérsia e não ao fato (admitido como existente pela sentença, se inexistente ou tido como inexistente pela sentença, se efetivamente existente) ${ }^{310}$.

Realmente, colhe-se da doutrina italiana, que esta não considera um pressuposto independente a ausência de pronunciamento judicial, estando sempre este ligado à ausência de controvérsia. A respeito cabe transcrever as palavras dos professores Federico Carpi e Michele Tarufo: “[...] non deve aver costituito un punto controverso in causa, sul quale la sentenza (della quale è chiesta la revocazione) si sia pronunciata"311.

Assim, também não nos parece correta a observação final feita por Barbosa Moreira, no trecho supra transcrito, quando refere, em abono de sua tese, que o pensamento da lei ao exigir a ausência de pronunciamento judicial sobre o ponto ou sobre $o$ fato, seria a desatenção do juiz sobre a prova. Ora, se o juiz afirmou existir fato, que se verificou inexistente, ou vice-versa, efetivamente não atentou para as provas. Destarte,

\footnotetext{
${ }^{310}$ Neste sentido a conclusão de Sydney Sanches, in Ação rescisória por erro de fato, cit., p. 61 e ss.

${ }^{311}$ In CARPI, Federico; TARUFFO, Michele. Commentario breve al codice di procedura civile, cit., p. 1172, grifos no original. No mesmo sentido: CALAMANDREI, Piero. La cassazione civile, cit., p. 226; SATTA, Salvatore. Diritto processuale civile, cit., p. 358; COMOGLIO, Luigi Paolo; FERRI, Corrado; TARUFFO, Michele. Lezioni sul processo civile, cit., p. 860; CHIOVENDA, Giuseppe. Instituições de direito processual civil, cit., v. 3, p. 278.
} 
justamente o pronunciamento judicial errôneo sobre o fato é que configura o erro de percepção do juiz no exame dos autos (e das provas nele produzidas).

A incorreta interpretação da norma quanto à ausência de pronunciamento judicial leva a soluções contraditórias, pois como bem lembrado por Flávio Yarshell, o exemplo típico de erro de fato colhido da jurisprudência é o não conhecimento do recurso por suposta intempestividade. Porém, como adverte o próprio autor, como tal hipótese atenderia o pressuposto da ausência de manifestação sobre o fato se a decisão se pronunciou sobre a intempestividade? 312

Ademais, conforme afirmado anteriormente 313 , a lei processual refere-se a duas hipóteses: de erro propriamente dito (na admissão de fato inexistente pela sentença, como existente) e de ignorância (ao afirmar como inexistente, fato efetivamente ocorrido). Nesse contexto, a eventual ausência de manifestação sobre o fato, somente pode-se dar no caso da ignorância ${ }^{314}$, pois na hipótese de erro propriamente dito, necessariamente haverá manifestação (errônea), na sentença, sobre o fato.

Ainda no que tange à ausência de pronunciamento judicial sobre a controvérsia (como corretamente deve ser entendido o alcance da norma em tela), é de se indagar se, no caso de julgamento colegiado, caso tenha havido pronunciamento sobre esta somente no voto vencido 315 , se será possível a ação rescisória por erro de fato? Entendemos que não, pois a questão não terá passado desapercebida pelo órgão julgador, visto que, por ocasião do proferimento do voto vencido, todos os demais componentes terão tomado conhecimento da controvérsia e se mantiveram seu entendimento, é porque não entenderam que o ponto era relevante para alterá-lo, tratando-se, quando muito, de má apreciação da prova, o que não dá ensejo à ação rescisória 316 .

\footnotetext{
${ }^{312}$ In YARSHELL, Flávio Luiz. Ação rescisória voltada contra decisão que reconhece a inadmissibilidade do recurso. In: DIDIER JR., Fredie (Coord.). Execução civil: estudos em homenagem ao professor Paulo Furtado. Rio de Janeiro: Lúmen Júris, 2006. p. 378.

${ }^{313}$ Na parte introdutória do presente capítulo, item I.1, parte 4.

${ }^{314}$ Se bem que, pela literalidade da norma, nunca o juiz poderá ter "saltado" sobre o ponto, pois, ou ele deverá admitir fato inexistente (portanto, houve pronunciamento - ainda que equivocado - sobre o fato) ou deverá considerar inexistente um fato efetivamente ocorrido (de novo, deveria haver pronunciamento judicial no sentido da inexistência do fato). Tal entendimento esvaziaria totalmente o conteúdo da norma, razão pela qual não pode ser admitido.

${ }^{315}$ Ou mesmo somente no voto de um ou alguns dos componentes da turma julgadora.

${ }^{316}$ Neste sentido, MOREIRA, Carlos Roberto Barbosa. Pronunciamento judicial sobre o fato e julgamento colegiado: interpretação do art. 485,§ $2^{\circ}$, do CPC. Revista de Processo, São Paulo, ano 26, n. 104, p. 150163, out./dez. 2001. Em sentido contrário: YARSHELL, Flávio Luiz. Tutela jurisdicional, cit., p. 340.
} 
Outra questão que pode provocar controvérsias a respeito da ausência de pronunciamento judicial é quando, não obstante a decisão rescindenda tenha se manifestado sobre certo documento em que se funda a controvérsia (um contrato, por exemplo), deixa de considerar uma certa cláusula (ignorando-a), ou considera como existente cláusula que efetivamente não se encontra redigida naquele contrato (agindo em erro). Nesse caso, deve-se permitir o manejo da ação rescisória por erro, pois presentes todos os pressupostos legais, visto que, não obstante ter se apercebido do documento que embasa a controvérsia, considerou fato (cláusula) inexistente como se escrita tivesse (ou vice-versa), ou seja, o erro é fruto da desatenção do juiz, não se cuidando de má apreciação da prova $^{317}$, pois a controvérsia sobre o ponto deve ser direta e específica 318 .

\section{I.3.3. Casos de erro de fato na jurisprudência italiana}

Somente a título ilustrativo, passaremos a elencar alguns dos casos considerados ou não como erro de fato passível de ensejar a "revocazione" pela jurisprudência italiana.

Conforme informado por Carpi e Taruffo, a jurisprudência italiana admite como erro de fato a ensejar a ação revocatória: em relação à prova testemunhal, o erro de fato só se configura da leitura e percepção literal e lógica do depoimento tomado e não na atividade posterior ao depoimento, qual seja, na interpretação e valoração do conteúdo do depoimento; a incorreta menção no acórdão acerca da notificação da sentença de primeiro grau, quando o contraste ficar evidente com os elementos dos autos; a omissão sobre existência ou inexistência de circunstâncias fáticas de naturezas decisivas, alegados pelo réu, quando se verificar que tais circunstâncias pudessem ser percebidas mediante a leitura

\footnotetext{
${ }^{317}$ Haveria má apreciação da prova, caso a decisão interpretasse errônea ou equivocadamente a cláusula em questão, situação que não permitiria a utilização da via rescisória.

${ }^{318}$ Neste sentido, Alessio que ressalta, exemplificando: “[...] e la controversia dev'essere diretta, direi quase specifica, altrimenti più che falso giudizio vi sarà sempre falso supposto. Ponete che le parti abbiano discusso se siasi verificata o no una prescrizione, a causa della validità o meno di un atto interruttivo. Il giudice rigetta l'eccezione di prescrizione, ritenendo l'invalidità dell'interruzione, ma aggiungendo mancare ad ogni modo lo spazio di tempo voluto dalla legge; però egli ha equivocato sulla data del titolo. Ebbene vi è senza dubbio luogo a revocazione, perciocchè, sebbene siasi discusso sulla prescrizione, non si era mai fatto quistione della data. Opportunamente la legge richiede che si tratti di un punto controverso, e non di un capo o di una quistione della causa." (ALESSIO, Giovanni. La revocazione delle sentenze civili, cit., p. 84).
} 
dos documentos; a incompleta valoração de um documento da causa; a falta de notificação à parte, da data da audiência 319 .

Não são considerados erro de fato para a ação de revogação: erro que se refira à atividade valorativa do juiz das situações processuais; é considerado erro de direito a questão relativa à idoneidade do ato notificatório que determina o prazo inicial para impugnação; a errônea interpretação de um contrato 320 .

Outro caso interessante analisado pela jurisprudência italiana, colacionado por Colesanti ${ }^{321}$, não obstante não se cuidar especificamente de erro de fato, diz respeito a um determinado caso em que a decisão havia sido proferida tendo como fundamento único outra decisão precedente, a qual, posteriormente, havia sido revogada. Conforme aponta o autor, solução estritamente formal seria considerar a segunda sentença inatacável, por não haver nenhuma previsão legal sobre tal situação. Mas, tal seria inaceitável. A solução encontrada pela jurisprudência foi revogar a segunda sentença pelo mesmo motivo pelo qual a primeira havia sido revogada, sob argumento de que, a parte conseguira vitória com seu comportamento doloso e, tal comportamento persistira no segundo julgamento, em que se utilizou a decisão anterior que estava viciada.

\section{I.4. Erro de direito}

\section{I.4.1. Introdução}

O meio típico para arguição do erro de direito é o previsto, de modo genérico, no inciso V, do artigo 485 do Código de Processo Civil, ao qual o presente trabalho se circunscreve 322 .

\footnotetext{
${ }^{319}$ In CARPI, Federico; TARUFFO, Michele. Commentario breve al codice di procedura civile, cit., p. 1172 ${ }_{320}$ e ss.

In CARPI, Federico; TARUFFO, Michele. Commentario breve al codice di procedura civile, cit., p. 1172 e ss.

${ }^{321}$ In COLESANTI, Vittorio. Sentenza civile (revocazione della), cit., p. 1170.

${ }^{322}$ Mas isso não significa que o inciso V é o único do art. 485 que prevê a rescisória por erro de direito, pois, em, pelo menos, nos incisos II e IV também haverá erro de direito, isso, sem mencionar nas possíveis hipóteses que se pode alegar também erro de direito para os demais incisos, como por exemplo, no caso do inciso I, certamente o juiz terá violado, pelo menos, alguma norma de direito penal, ou ainda, no caso do
} 
Com relação à ação rescisória por "violação a literal disposição de lei", a doutrina já assentou entendimento de que cabe ao autor da rescisória indicar a norma tida por violada, embora não seja necessário precisar especificamente o artigo ou parágrafo violado, bem como pode ser relevado eventual equívoco ao mencioná-los 323 .

\section{I.4.2. Violação à literal disposição de lei}

\section{a) prequestionamento}

Não se mostra indispensável que a norma tida por violada tenha sido suscitada no processo em que se proferiu a decisão rescindenda, dispensando-se o prequestionamento, pois conforme observa Barbosa Moreira, cumpria ao órgão judiciário que proferiu a decisão rescindida a correta aplicação da lei ao caso concreto, mesmo no silêncio das partes (iura novit curia) ${ }^{324}$. Porém, não cabe ação rescisória se a matéria não pude ser conhecida de ofício e não foi alegada oportunamente pela parte interessada (v.g. as exceções processuais e a compensação), na medida em que, nesse caso, a decisão rescindenda não terá incidindo em erro, visto estar defesa de conhecer da matéria de ofício 325 .

\section{b) sentido do termo "literal"}

A doutrina majoritária se posiciona no sentido de que a expressão literal não exige que a lei (ou a norma) deva estar escrita 326 , ou que deva constar literalmente de

inciso III, as partes podem ter infringido algum dispositivo de direito material etc, mas se fôssemos imaginar todas as hipóteses possíveis, isso tornaria o trabalha vago e impreciso, não sendo proveitoso, razão pela qual iremos nos cingir à análise do inciso $\mathrm{V}$, do art. 485 do $\mathrm{CPC}$, nessa parte.

${ }^{323}$ Neste sentido: PONTES DE MIRANDA, Francisco Cavalcanti. Tratado da ação rescisória das sentenças $e$ de outras decisões. Rio de Janeiro: Forense, 1976. p. 292, BARBOSA MOREIRA, José Carlos. Comentários ao Código de Processo Civil, cit., p. 132.

${ }^{324}$ Ver a respeito: BARBOSA MOREIRA, José Carlos. Comentários ao Código de Processo Civil, cit., p. 132.

${ }^{325}$ A propósito, PONTES DE MIRANDA, Francisco Cavalcanti.Tratado da ação rescisória das sentenças $e$ de outras decisões, cit., p. 293 e 300.

${ }^{326}$ Em sentido contrário, RIZZI, Sérgio. Ação rescisória, cit., p. 105 e PEREIRA, Rosalina Pinto da Costa Rodrigues. O art. 485, V, do Código de Processo Civil. Revista de Processo, São Paulo, ano 22, n. 86, p. 126, abr./jun. 1997, entendendo pela necessidade de a norma estar escrita, apesar de, mais adiante (p. 127 e ss.) admitirem a ação rescisória contra princípio geral do direito não escrito. 
texto algum. Também não significa que a interpretação que se deva dar à norma, para que se configure a violação passível de ação rescisória, deva ser literal, pois, dessa forma, estar-se-ia reduzindo o alcance da norma.

Não se exige, outrossim, que a lei seja "clara", pois sendo esta obscura, deverá o intérprete extrair o seu comando, o seu sentido, e verificar se a decisão que se pretende rescindir violou ou não este comando 327 . A propósito, vale transcrever as sábias palavras do mestre Pontes de Miranda, segundo o qual, "O esforço que possa custar ao juiz para obter a interpretação certa não importa. Iura novit curia. O juiz tem de saber e de dizer a lei: se o não diz, ou se entende que lhe vai custar muito encontrar o senso da lei, não interessa à ordem jurídica. O defeito, a deficiência, a defecção é dele"328.

Despiciendo, ainda, que a violação seja expressa, flagrante, pois a norma é que deve ser expressa. Verifica-se que, na maioria das vezes, a violação se dá de modo dissimulado, velado, usando o órgão prolator da decisão de subterfúgios ou raciocínios viciados, que visam a amparar a sua decisão, ocorrendo a violação de modo inconsciente, não intencional. Raras serão as hipóteses em que se verificará a violação frontal e explícita da norma 329330 . Convém citar os esclarecimentos do professor Dinamarco a respeito do tema, que enfatiza, com propriedade: "Diretamente e em sã consciência nenhum juiz nega vigência a uma lei, ou transgride de modo descarado e confesso o que ela dispõe. Mas tão ingênuo quanto seria o juiz que o fizesse, seria também o tribunal que negasse a revisão de sentenças ou acórdãos, iludido por dissimulações"331. E o mestre continua, citando interessante passagem de Aliomar Baleeiros, segundo o qual o juiz só nega vigência a uma lei quando aplica mal uma norma de direito intertemporal ou de direito internacional privado, ou em caso de loucura furiosa.

${ }^{327}$ Assim PONTES DE MIRANDA, Francisco Cavalcanti. Tratado da ação rescisória das sentenças e de outras decisões, cit., p. 267.

${ }^{328}$ Tratado da ação rescisória das sentenças e de outras decisões, cit., p. 276.

${ }^{329}$ Conforme doutrina Pontes de Miranda: “A violação independe das simulações e dissimulações dos juízes, das suas tiradas eruditas, das suas referências e louvaminhas ao próprio texto que vai violar ou já violou. A violação aprecia-se in concreto." (Tratado da ação rescisória das sentenças e de outras decisões, cit., p. 302).

${ }^{330}$ A propósito, Liebman, tecendo comentários sobre lei brasileira, cita uma decisão do Supremo Tribunal Federal, de 1941, atestando que este tribunal teria afirmado, em relação à violação da lei para a ação rescisória, que o intérprete e o juiz não devem tanto se preocupar de modo direto ou indireto, declarado ou implícito, da ofensa ao teor da lei, mas, ao contrário, devem considerar a extensão e a gravidade desta ofensa, admitindo a ofensa ao direito expresso somente quando esta for grave, flagrante, não suscetível de dúvida ou incerteza, o que não nos parece ser a orientação mais adequada sobre o tema. (LIEBMAN, Enrico Tullio. Problemi del processo civile. Napoli: Morano, 1962. p. 513).

${ }^{331}$ In DINAMARCO, Cândido Rangel. Fundamentos do processo civil moderno, cit., v. 2, p. 998. 


\section{c) extensão do termo "lei"}

A doutrina 332 é uníssona em afirmar que deve se atribuir um sentido amplo ao termo "lei", abrangendo não só a lei sem sentido estrito, mas todas as normas de uma maneira geral. A acepção que se deve dar à expressão "lei" é a mais ampla possível, entendida esta como o direito em tese, o sistema legal, importando a proteção a qualquer norma, regra ou princípio abarcados pelo sistema, formado por todo o ordenamento jurídico. O conceito deve ser entendido sob a ótica do escopo social da jurisdição, que visa à eliminação do conflito mediante critérios justos 333 . Assim, cada vez que esses critérios pré-estabelecidos pelo sistema não forem observados, deve-se entender viável a ação rescisória por violação à literal disposição de lei. Caso contrário, não se atingirá a desejada pacificação social, permitindo-se a disseminação de injustiças através do meio estatal de solução de controvérsias, contrariando seus escopos.

Também não se deve fazer qualquer distinção quanto ao tipo de norma passível de ensejar a ação rescisória, podendo tanto ser norma de caráter federal, estadual ou municipal, ou até mesmo internacional (quando aplicável), bem como norma de direito material ou processual, pois não há qualquer restrição nesse sentido no texto legal.

Como bem observado por Pontes de Miranda, muito provavelmente o direito objetivo seria irrealizável se baseado exclusivamente na lei, não somente em razão da inevitabilidade das lacunas, bem como a solução dessas e as imperfeições do sistema pressupõem a atuação dos princípios gerais 334 .

Nessa medida, é pacífica a concepção na doutrina de que estariam compreendidos no termo os princípios gerais do direito, entendendo-se que a violação a um princípio, em razão do papel que desempenham no sistema, conferindo valores e

\footnotetext{
${ }^{332}$ V. PONTES DE MIRANDA, Francisco Cavalcanti. Tratado da ação rescisória das sentenças e de outras decisões, cit., p. 266 e ss., BARBOSA MOREIRA, José Carlos. Comentários ao Código de Processo Civil, cit., p. 130 e ss., YARSHELL, Flávio Luiz. Tutela jurisdicional, cit., p. 323 e ss.

${ }^{333}$ Vide capítulo II, da parte 1 do presente trabalho.

${ }^{334}$ Conforme PONTES DE MIRANDA, Francisco Cavalcanti. Tratado da ação rescisória das sentenças e de outras decisões, cit., p. 269.
} 
orientações axiológicas genéricas, é muito mais nociva ao sistema do que a ofensa a dispositivos legais 335 .

Mais controvertida é a questão da possibilidade de ação rescisória com base no inciso V, do artigo 485 do Código de Processo Civil quando houver violação ao costume ou à uma regra por analogia, inclinando-se a maioria da doutrina pela sua possibilidade, pois, nos termos do artigo $4^{\circ}$ da Lei de Introdução ao Código Civil e do artigo 126 do Código de Processo Civil, tais institutos integram o sistema legal, o que se nos afigura mais correto 336 .

Questão mais complexa existe em relação à violação de súmula jurisprudencial. A doutrina parece sempre ter se inclinado no sentido de não admitir a ação rescisória por violação de lei quando a decisão contrariar entendimento sumulado, pois estes não estariam abrangidos pelos artigos supra mencionados e, principalmente, em razão de estes não possuírem caráter vinculante, tratando-se de simples orientações ou parâmetros para interpretação e aplicação das normas 337 .

Todavia, a discussão ganhou novos contornos com a promulgação da Emenda Constitucional 45/2004, que introduziu a súmula vinculante no nosso ordenamento, determinando expressamente que a súmula editada nesses termos possui "efeito vinculante em relação aos demais órgãos do Poder Judiciário e à administração pública direta e indireta, nas esferas federal, estadual e municipal”. Nesses termos, a súmula vinculante preenche todos os requisitos para ser tratada como norma jurídica, visto que de caráter geral e abstrato e vinculante; portanto, a sua violação deve abrir caminho à ação rescisória por violação à literal disposição de lei, desde que preenchidos os demais requisitos 338 .

\footnotetext{
${ }^{335}$ Assim se manifestaram WAMBIER, Teresa Arruda Alvim; MEDINA, José Miguel Garcia. $O$ dogma da coisa julgada: hipóteses de relativização, cit., p. 170 e ss.

${ }^{336}$ Conforme o mestre Pontes de Miranda, toda regra, de qualquer procedência que seja, desde que realizável na prática deve ser considerada direito e como tal, sua violação torna possível o manejo da ação rescisória, com base no inciso V, do art. 485, do CPC (PONTES DE MIRANDA, Francisco Cavalcanti. Tratado da ação rescisória das sentenças e de outras decisões, cit., p. 271).

${ }^{337}$ Ver por todos, BARBOSA MOREIRA, José Carlos. Comentários ao Código de Processo Civil, cit., p. 132.

${ }^{338}$ Neste sentido, Izabelle Maia, Violação à súmula vinculante e cabimento de ação rescisória. In: FUX, Luiz et al. (Coord.). Processo e Constituição: estudos em homenagem ao professor José Carlos Barbosa Moreira. São Paulo: Ed. Revista dos Tribunais, 2006. p. 240 e ss.
} 


\section{d) error in procedendo e error in iudicando}

O error in procedendo é qualificado por autorizada doutrina como vícios de invalidade relativos ao procedimento, e os errores in iudicando como erros de juízo, podendo dizer respeito a erros de interpretação, aplicação ou de subsunção dos fatos à norma, ou ainda, na incorreta valoração dos fatos controversos, redundando ambos (tanto erros de direito como erros de fato) na injustiça da decisão 339 . Os primeiros são os vícios de atividade, que levam à nulidade da sentença, enquanto que os segundo são vícios de juízo, determinando a injustiça da decisão.

Como já se disse, não é necessário para a viabilização da ação rescisória, que o vício esteja na sentença, podendo estar presente no curso do processo, sendo que seus efeitos podem propagar-se para a sentença, inquinando-a de nulidade ${ }^{340}$. Porém, não são todas as nulidades incorridas no curso do processo que atingem a sentença. Com efeito, os atos seguem o regime das nulidades aplicáveis ao processo ${ }^{341}$, ou seja, se se tratar de vício sanável e ocorrer a preclusão no curso no processo, este não poderá ser alegado como fundamento para ação rescisória, só as nulidades insanáveis, até porque, como já se disse, a coisa julgada funciona como uma "sanatória geral" do processo, somente sobrevivendo a ela as nulidades absolutas e, mesmo estas, após o decurso do prazo decadencial de dois anos, não podem mais ser alegadas 342 .

Nesse aspecto, cumpre esclarecer que não mais se concebe a antiga discussão que existia na doutrina em torno da possibilidade ou não do manejo da ação rescisória para denunciar os errores in procedendo. Tal se dava por razões históricas do instituto, tendo em vista que, originariamente, no direito romano, os errores in procedendo acarretavam a nulidade (inexistência) das decisões, enquanto que os errores in iudicando eram atacáveis por meio de recurso próprio (appellatio). Assim, os errores in procedendo, não cabendo no instrumento típico da appellatio podiam ser combatidos através da querela nullitatis, que

${ }^{339}$ Conforme COMOGLIO, Luigi Paolo; FERRI, Corrado; TARUFFO, Michele. Lezioni sul processo civile, cit., p. 782 e ss.

${ }^{340}$ Conforme capítulo I.1, parte 3.

${ }^{341}$ A esse respeito vigem os princípios da instrumentalidade das formas, ausência de prejuízo e da economia processual, conforme arts. 243 e seguintes do CPC. Ver a respeito, BEDAQUE, José Roberto dos Santos. Efetividade do processo e técnica processual. São Paulo: Malheiros Ed., 2007. esp. p. 408 e ss.

${ }^{342}$ Neste sentido, GONÇALVES, Daniella Zagari. A violação de literal disposição de lei como fundamento da ação rescisória no direito brasileiro. 2000. Dissertação (Mestrado) - Faculdade de Direito, Universidade de São Paulo. São Paulo, 2000. p. 267 e ss. 
poderiam ser sanabilis ou insanabilis, sendo que, no direito europeu, a primeira foi absorvida pela apelação e a segunda deixou de existir. Contudo, a possibilidade de controle dos errores in procedendo não está excluída da via rescisória no nosso ordenamento.

\section{e) Súmula 343 do STF}

Ainda no que concerne à ação rescisória por literal violação de lei, o Supremo Tribunal Federal editou sobre a matéria, Súmula 343, segundo a qual "não cabe ação rescisória por ofensa à literal disposição de lei, quando a decisão rescindenda se tiver baseado em texto legal de interpretação controvertida nos tribunais". Ou seja, se houver controvérsia a respeito da norma, não se abre a via rescisória para aquele que se sentir prejudicado, em razão da posterior orientação contrária à decisão que se formou no processo proferido ao tempo da controvérsia, uma vez que não se considera violação literal da lei quando houver interpretação razoável da norma, de um de seus sentidos possíveis. Argumenta a jurisprudência que, caso assim não fosse, a ação rescisória se transformaria em recurso "ordinário", com prazo de interposição de dois anos. Tal súmula não se aplica se, quando do julgamento originário, a controvérsia já tiver sido superada.

Referida súmula sempre recebeu muitas críticas da doutrina em razão de ir esta contra os princípios da legalidade e o da isonomia, visto que a lei é uma só e deve ser aplicada igualmente para todos que se veem na mesma situação diante da norma 343 . Porém, doutrina e jurisprudência têm afastado a incidência da Súmula 343 quando se tratar de violação de norma constitucional, pois não seria lícito falar em interpretação razoável do texto constitucional ${ }^{344}$.

Ocorre que, recentemente, os tribunais superiores vêm manifestando entendimento no sentido de abrandar ou afastar a incidência da Súmula 343, sinalizando

\footnotetext{
${ }^{343}$ Ver a respeito, Teresa Wambier, "Sobre a súmula 343”, tachando a referida súmula de inconstitucional justamente por violar os princípios constitucionais citados.

${ }^{344}$ Conforme pondera Ada Pellegrini Grinover, a posição majoritária do Supremo Tribunal Federal é no sentido de se entender cabível a ação rescisória, afastando a súmula 343, quando a declaração de inconstitucionalidade se der através de ação direita, com efeitos ex tunc, ou ainda, na hipótese de, no controle difuso, havendo suspensão da lei pelo Senado, de acordo com entendimento do Supremo Tribunal Federal, este poderia se dar ex tunc, viabilizando também a ação rescisória. Nos demais casos em que a declaração possui efeitos ex nunc ou ainda, na declaração de constitucionalidade, que nada nulifica, perfeitamente aplicável à súmula 343. (GRINOVER, Ada Pellegrini. Ação rescisória e divergência de interpretação em matéria constitucional. In: Universitária, 2000. p. 14 e ss). - A marcha do processo. São Paulo: Forense
} 
uma disposição em rever o texto da referida súmula. Com efeito, conforme pondera o ministro Teori Albino Zavascki ${ }^{345}$, com a promulgação da Constituição de 1988, que conferiu função institucional ao Superior Tribunal de Justiça como guardião da legislação federal, zelando pela sua correta e uniforme aplicação, este não pode mais contentar-se com interpretação de lei "menos exata". Argumenta, ainda, que não se pode abrir mão da isonomia em nome da segurança jurídica, bem como que o entendimento da interpretação razoável está na contra-mão do movimento evolutivo do nosso direito, que caminha cada vez mais no sentido de conferir maior relevo vinculativo aos precedentes dos Tribunais Superiores.

Nessa medida, conclui que é plenamente justificável a revisão da súmula 343, demonstrando que existe, pelo menos, certa oscilação na aplicação da referida súmula, com tendência cada vez maior no sentido de entendê-la inaplicável.

\section{I.5. Erro material e erro de cálculo}

Nos termos do artigo 463, I, do Código de Processo Civil, após a publicação da sentença, o juiz poderá, de ofício ou a requerimento da parte, corrigir inexatidões materiais (erro material) ou erros de cálculo. As inexatidões materiais ou erros de cálculos emergem do próprio texto da sentença. Nas palavras de Chiovenda, o erro material refere-se somente à manifestação exterior da vontade do juiz e não à própria vontade ${ }^{346}$; consiste, assim, num erro de forma (de exteriorização) de julgamento e não no conteúdo do mesmo ${ }^{347}$.

Consiste em mero erro material, por exemplo, a grafia incorreta do nome das partes, erros de data, condenar o autor nas verbas de sucumbência, quando a demanda for julgada totalmente procedente, a inclusão de um zero a mais no valor da condenação etc. $O$ erro de cálculo são equívocos aritméticos, que "levam o juiz a concluir por valores mais elevados ou mais baixos"348 do que o devido. Ambos devem ser caracterizados e

\footnotetext{
${ }^{345}$ In ZAVASCKI, Teori Albino. Ação rescisória: a súmula n. 343-STF e as funções institucionais do Superior Tribunal de Justiça. In: SUPERIOR Tribunal de Justiça: doutrina: edição comemorativa, 20 anos. Brasília/DF: STJ, 2009. p. 80 e ss.

${ }^{346}$ In CHIOVENDA, Giuseppe. Instituições de direito processual civil, cit., v. 3, p. 278.

${ }^{347}$ Ver a propósito, Eduardo Talamini, Coisa julgada e sua revisão. São Paulo: Ed. Revista dos Tribunais, 2005. p. 527.

${ }^{348}$ DINAMARCO, Cândido Rangel. Instituições de direito processual civil, cit., v. 3, p. 718.
} 
corrigidos a partir de critérios objetivos, bastando a simples leitura da decisão para que sejam constatados.

Não se incluem no erro de cálculo eventuais erros dos critérios estabelecidos para elaboração do cálculo, ou seja, erros de escolha, os quais, quando muito, podem caracterizar-se como error in iudicando, não incluídos na hipótese em tela. Assim, não se qualifica como erro material ou erro de cálculo a fixação de determinado índice de correção monetária, taxa de juros etc.

Os referidos erros não se sujeitam a preclusão nem a coisa julgada, podendo ser corrigidos a qualquer tempo, inclusive na execução, até porque, não importam propriamente em alteração da decisão (e assim, ofensa a coisa julgada), ao contrário, corrigindo-os, faz-se com que a vontade do julgador seja corretamente observada. Trata-se de expressão do princípio geral da razoabilidade ${ }^{349}$.

Conforme bem observou Flávio Yarshell, não há necessidade sequer de se abrir o contraditório para correção de tais erros (os quais, como se adiantou, podem ser corrigidos até de ofício), posto não se tratar propriamente de alteração do julgamento ${ }^{350}$, atendendo, referida regra, ao princípio da economia processual, pois seria contrária ao mesmo a solução que exigisse a interposição dos meios de impugnação para que a parte prejudicada pelo erro pudesse fazer valer o seu direito 351 .

\footnotetext{
${ }^{349}$ Neste sentido, TALAMINI, Eduardo. Coisa julgada e sua revisão, cit.,, p. 531.

${ }^{350}$ YARSHELL, Flávio Luiz. Tutela jurisdicional, cit., p. 56.

${ }^{351}$ Tutela jurisdicional, cit., p. 62. Mais adiante no texto, continua o autor a analisar a questão do erro material,quando este importe na total desconstituição da sentença, afirmando ser necessário estabelecer um limite temporal para que o órgão prolator casse sua própria sentença. Porém, na hipótese aventada pelo autor, s.m.j., não nos parece tratar-se de erro material, pois este, como visto, é erro na manifestação da vontade, e a sua correção importa na correta observação da sentença, nunca na sua desconstituição. O autor dá como exemplo, um caso em que fora decretada extinção da execução fiscal com base em pagamento da dívida, por sentença proferida há mais de quatro anos, vindo a parte a verificar, posteriormente que o termo de quitação juntado aos autos não se referia àquela dívida executada. Nessa hipótese, não nos parece tratarse de erro material, pois não seria o caso de o juiz querer dizer uma coisa e dizer outra, haveria, se presentes os demais requisitos, fundamento para ação rescisória por erro de fato (Tutela jurisdicional, cit., p. 63 e ss.). A correção do erro de fato não pode implicar na desconstituição da sentença, ao contrário, visa justamente a conduzir a sua exata observância.
} 


\section{DIFERENCIAÇÃO ENTRE ERRO DE FATO, ERRO DE DIREITO E DEMAIS CAUSAS DE PEDIR}

Nesse aspecto, cabe lembrar que a ação rescisória possui um elenco fechado em relação às possíveis causas de pedir passíveis de embasar a ação rescisória, conforme relação contida no artigo 485 do Código de Processo Civil.

Barbosa Moreira 352 esclarece que cada um dos incisos do artigo 485 da lei processual corresponde a uma causa de pedir e que, portanto, trata-se, em sua totalidade, de questões de fato (inclusive a relativa à violação de literal disposição de lei) a serem narradas pelo autor da ação rescisória como fundamento do seu pedido. E, como se sabe, as questões de fato devem ser sempre alegadas pelo interessado, sendo vedado, nesta sede, o conhecimento de ofício pelo juiz de fatos não alegados, conforme regra do artigo 128 do Código de Processo Civil, uma vez que o juiz deve se ater aos fatos suscitados pelas partes, estando impedido de trazer questões novas à lide.

Aplica-se, outrossim, à ação rescisória o princípio do iura novit curia, ou seja, não é incumbência do autor indicar o inciso em que esta estaria lastreada 353 ou não haveria problema em que este houvesse indicado inciso incorreto. Assim, a incorreta indicação do inciso ou até mesmo a sua falta, não induz à extinção ou improcedência da ação rescisória.

Porém, a parte deve indicar precisamente os fatos que embasam o seu pedido, isto é, que seriam suficientes para a rescisão do julgado. Dessa forma, cumpre ao autor indicar, por exemplo, a norma violada pela decisão de mérito (art. 485, V, do CPC), ou o erro de fato em que o decisum se baseou (art. 485, IX, do CPC).

Cada um dos incisos do artigo 485 do Código de Processo Civil representa uma causa de pedir para a ação rescisória, independentes e autônomas entre si. Contudo, nada obsta que, presentes os requisitos, a parte cumule várias causas de pedir para a ação rescisória, originárias de fatos diversos, ou ainda, que um mesmo fato (causa de pedir

\footnotetext{
${ }^{352}$ BARBOSA MOREIRA, José Carlos. Considerações sobre a causa de pedir na ação rescisória. In: Temas de direito processual: $4^{\mathrm{a}}$ série. São Paulo: Saraiva, 1988. p. 210 e ss.

${ }^{353}$ Neste sentido: CRUZ E TUCCI, José Rogério. A causa petendi no processo civil. São Paulo: Ed. revista dos Tribunais, 2001 e BARBOSA MOREIRA, José Carlos. Comentários ao Código de Processo Civil, cit.
} 
remota) dê azo a mais de um fundamento (causa de pedir próxima) para uma ação rescisória.

Para a ação rescisória por erro de direito é indiferente se as partes tenham ou não discutido acerca da norma tida por violada, pois, como anteriormente asseverado, não se exige o prequestionamento (iura novit curia), enquanto que, para a ação rescisória por erro de fato, de lege lata, é necessário que não tenha havido controvérsia sobre o fato. Quanto ao pronunciamento judicial, a violação pode ter havido por inaplicação de norma que deveria incidir, aplicação de outra norma ou incorreta interpretação da norma. No que tange ao erro de direito, viu-se que não pode ter havido pronunciamento judicial acerca da controvérsia fática.

Pode ocorrer, ainda, que ao dar por existente algum fato ou por inexistente fato ocorrido (erro de fato), pode o juiz ter violado alguma norma (por exemplo, de qualificação jurídica ou regra de interpretação da prova ${ }^{354}$ ) e, assim, possibilitar a ação rescisória também por erro de direito. Nesse aspecto, cumpre lembrar que, a exigência de inexistência de pronunciamento judicial sobre a controvérsia somente vige para o erro de fato, destarte, caso ocorra o pronunciamento judicial (equivocado, na hipótese) sobre a controvérsia, exclui-se somente a possibilidade de ação rescisória por erro de fato, mas não por erro de direito.

Com relação às demais causas de pedir, provavelmente, na hipótese do inciso I (prevaricação, concussão ou corrupção do juiz) o julgador pode ter violado alguma norma de direito penal ou da lei orgânica da magistratura nacional, podendo-se cumular as causas de pedir do inciso I e do inciso V, do artigo 485 do Código de Processo Civil, para um mesmo fato. O mesmo pode se dar com relação aos incisos II (juiz impedido ou absolutamente incompetente) e IV (ofensa à coisa julgada) do citado dispositivo legal, cabendo, também, a ação rescisória por duplo fundamento.

No caso da sentença ter se baseado em prova falsa e esta prova ter levado o juiz a admitir fato inexistente ou vice-versa, só será possível a ação rescisória com base no inciso VI e não no inciso IX, uma vez que não terá havido erro do juiz propriamente dito, pois ele terá pronunciado decisão com base nos documentos então existentes.

\footnotetext{
${ }^{354}$ Que permite a ação rescisória por violação à literal disposição de lei, conforme DINAMARCO, Cãndido Rangel. Fundamentos do processo civil moderno, cit., v. 2, p. 988 e ss.
} 
Finalmente, na hipótese do inciso VII (documento novo), igualmente não se confunde com o erro de fato, pois, como é curial, no caso de erro de fato o documento já deve constar dos autos na ação originária (em que se proferiu a decisão rescindenda), o que não se dá na hipótese de documento novo. Novamente, caso com o documento novo se comprove que fato admitido na sentença não existiu, ou vice-versa, não será possível o manejo da ação rescisória com base em erro de fato pelo mesmo motivo do inciso VI, ou seja, não terá havido erro do juiz. 


\section{A POSIÇÃO DOS TRIBUNAIS SUPERIORES A RESPEITO DA RESCISÓRIA FUNDADA EM ERRO}

Nesse capítulo, iremos analisar como os tribunais superiores (Superior Tribunal de Justiça e Supremo Tribunal Federal) se posicionam frente às questões mais polêmicas apresentadas no presente trabalho, com ênfase à ação rescisória por erro.

Com relação à admissibilidade da ação rescisória contra sentença ou decisão proferida em processo de execução, a jurisprudência dos tribunais superiores é maciçamente favorável a sua admissão, sendo que em muitas das decisões, nem sequer há discussão sobre seu cabimento. A respeito, vale destacar o posicionamento constante da seguinte ementa:

"1. A sentença que extingue a execução tem conteúdo declaratório (art. 795 do CPC), nela ficando reconhecida a ocorrência do fato jurídico que deu causa ao encerramento da execução.

2. No caso dos autos, a execução foi extinta pelo pagamento (art. 794, I, do CPC), sendo que o crédito cuja extinção se declarou por sentença é aquele relativo à reparação por danos morais, no valor de quarenta salários-mínimos. Sobre esse fato jurídico recai a qualidade de coisa julgada material, sendo vedado ao credor, como não poderia deixar de ser, ingressar com nova execução para exigir o adimplemento dessa mesma obrigação." ${ }^{355}$

No que tange ao entendimento do que consiste sentença de mérito, passível de ensejar a ação rescisória, os tribunais superiores também têm entendimento amplo, entendendo possível a ação rescisória de qualquer decisão que tenha decidido o mérito da controvérsia, inclusive decisão interlocutória, utilizando como critério tratar-se de decisão substancialmente de mérito, conforme a seguinte ementa:

"1. "Sentença de mérito" a que se refere o art. 485 do CPC, sujeita a ação rescisória, é toda a decisão judicial (= sentença em sentido estrito, acórdão ou decisão interlocutória) que faça juízo sobre a existência ou a inexistência ou o modo de ser da relação de direito material objeto da demanda.

\footnotetext{
${ }^{355}$ STJ, REsp. no 691785/RJ, rel. Min. Raul Araújo, DJe 20/10/10. No mesmo sentido: EDcl no REsp 1143471/PR, rel. Min. Luiz Fux, DJe 19/08/10; AgRg no REsp 1173662/RS, rel. Min. Castro Meira, DJe 17/05/10, REsp 15622/SP, rel. p/ acórdão Min. Demócrito Reinaldo, DJ 13/03/95, REsp 100902/BA, rel. Min. Cesar Asfor Rocha, DJ 29/09/97 e REsp 147735/SP, rel. Min. Vicente Leal, DJ 12/06/00. Em sentido contrário, entendendo não ser possível ação rescisória de decisão em execução, porém, em razão de ter sido extinta por acordo homologado: AR 774/SP, rel. Min. Eliana Calmon, DJ 19/06/00.
} 
2. Está sujeito a ação rescisória, portanto, o acórdão que indefere pedido de redirecionamento da execução fiscal contra sócio por entender inexistente a sua responsabilidade tributária." 356

Quanto à possibilidade de ação rescisória contra decisão homologatória de sentença estrangeira, o Supremo Tribunal Federal já se posicionou favoravelmente, conforme decisão proferida na AR 1169/SP, de relatoria do Ministro Eros Grau, julgado em 03/08/09.

No que tange à aplicabilidade do princípio iura novit curia à ação rescisória, ou seja, quando o autor tenha proposto a rescisória com base em um dos incisos do artigo 485 do Código de Processo Civil, mas na realidade ficar caracterizado tratar-se de outra hipótese, os tribunais superiores entendem possível o enquadramento na hipótese correta, desde que o autor tenha feito corretamente a descrição dos fatos, porém, os tribunais não podem conhecer, de ofício, de causa que não tenha sido alegada pelo autor, não obstante verificarem existir outra causa para a rescisória357. Porém, em sentido contrário à aplicação do princípio, decidiu o Supremo Tribunal Federal, no julgamento da AR 1037/SP, relatada pelo Ministro Alfredo Buzaid, julgada em 03/05/84, tendo os ministros expressamente declarado que, não obstante o autor ter proposto a ação rescisória com base no inciso V, por violação a literal texto de lei, seria a hipótese de erro de fato (inciso IX) e, caso o autor tivesse enquadrado os fatos corretamente no inciso citado, seria a hipótese de procedência da demanda rescisória, mas, ante o fundamento jurídico incorretamente suscitado, negou-se provimento à ação em tela, vencido o Ministro revisor, Oscar Corrêa.

Outra importante questão relativa à ação rescisória diz respeito ao âmbito de sua atuação, especialmente quanto à possibilidade de revisão da justiça da decisão rescindenda, não existindo consenso na jurisprudência sobre o tema. Em sua maioria, as decisões declaram não ser possível a revisão da "justiça das decisões" pela via rescisória, chegando-se até a afirmar, de maneira equivocada, não ser possível o exame do error in iudicando por meio da rescisória, conforme a seguinte decisão:

\footnotetext{
${ }^{356}$ STJ, REsp 784799/PR, rel. Min. Teori Albino Zavascki, DJe 02/02/10. No mesmo sentido: REsp 100902/BA, rel. Min. Cesar Asfor Rocha, DJ 29/09/97, AR 2099/SE, rel. Min. Arnaldo Esteves Lima, DJ 24/09/07 e REsp 628464/GO, rel. Min. Nancy Andrighi, DJ 27/11/06.

${ }^{357}$ Neste sentido: STJ, AR 3760/PR, rel. Min. Luiz Fux, DJe 10/09/10, entendeu não incidente o princípio, pois não tinham sido narrados os fatos para conhecimento da rescisória por inciso diverso do pleiteado; AR 4446/SP, rel. Min. Eliana Calmon, DJe 10/09/10 e AR 3565/PR, rel. Min. Felix Fischer, DJe 30/06/08, aplicaram princípio, pois o autor havia narrado os fatos corretamente, somente indicando o inciso do art. 485, CPC de forma equivocada.
} 
"Imperioso, ainda, assentar que o julgamento supostamente injusto (error in judicando), não autoriza o manejo da Ação Rescisória, por isso que o fundamento da coisa julgada não é a justiça da decisão nem o seu conformismo com a verdade (pro veritate habetur), mas antes compromisso político com a segurança social.",358

Porém, o próprio Ministro Luiz Fux, relator do acórdão da ementa supra transcrita, em outra oportunidade, admitiu expressamente a possibilidade de se denunciar a existência de error in iudicando através da ação rescisória, in verbis:

"O art. 485 do CPC prevê, em numerus clausus, as causas de rescindibilidade viabilizadoras da propositura da ação rescisória, dentre as quais encontra-se incluída a violação de literal disposição de lei que pode decorrer tanto de error in judicando como de error in procedendo." ${ }^{359}$

Não obstante a maior parte das decisões consignar expressamente a inviabilidade da ação rescisória para exame da justiça da decisão ${ }^{360}$, existem outras tantas decisões que, ora de forma implícita, ora de forma explícita, admitem manejo da ação rescisória com escopo (não único, pois este efetivamente não é o escopo da rescisória, porém, não é causa excludente) de revisão do valor justiça ${ }^{361}$ existente na decisão rescindenda.

De fato, admitem expressamente a análise da justiça da decisão rescindenda:

"1. Há de ser reformado acórdão que entendeu não ser cabível a via rescisória com intuito de desconstituir julgado que não apreciou o mérito da demanda (apenas declarou a intempestividade do agravo de instrumento interposto). Porquanto o acórdão rescindendo não tenha enfrentado o mérito, consoante pressupõe o caput do art. 485 do CPC, o seu inciso IX admite a rescisória fundada em erro de fato.

$[\ldots]$

\footnotetext{
${ }^{358}$ STJ, AgRg na AR 4439/PR, rel. Min. Luiz Fux, DJe 01/10/10, no mesmo sentido: REsp. 954.720/RJ, com a mesma redação; AR 1084/SP, rel. Min. Mauro Campbell Marques, DJe 15/03/10.

${ }^{359}$ STJ, AgRg no REsp 707363/MG, DJ 03/04/06. Pela possibilidade da verificação do error in iudicando, também: REsp 91.999/SP, rel. Min. Hamilton Carvalhido, DJ 19/12/02.

${ }^{360}$ Além das decisões supra transcritas, entendem inviável o exame da justiça das decisões por meio da rescisória: REsp. 1.128.929/PR, rel. Min. Nancy Andrighi, DJe 06/10/10; REsp. 1.105.134/PR, rel. Min. Massami Uyeda, DJe 22/06/10; STJ, AgRg na AR 3509/PR, rel. Min. Luiz Fux, DJ 25/09/06 e STJ, AR 464/RJ, rel. Min. Barros Monteiro, DJ 19/12/03.

${ }^{361}$ Não se está aqui a defender a viabilidade da ação rescisória exclusivamente para revisão da justiça da decisão, pois efetivamente a ação rescisória não se presta a tal função, porém, o que se pretende ressaltar é que, estando preenchidos os demais requisitos da ação rescisória, não fica pré-excluída a verificação da justiça da decisão rescindenda, ao contrário, estar-se-á fazendo justiça ao caso concreto, não sendo este, portanto, um critério válido para verificação da possibilidade ou não da ação rescisória.
} 
4. Se de um lado é dever do advogado ser diligente, protocolizando oportunamente suas peças processuais, do outro é obrigação do julgador, na sua missão constitucional de dizer o direito ao caso concreto, utilizarse de critérios conducentes à decisão mais justa possível, proporcionando ao jurisdicionado a certeza de que a tutela foi efetivamente prestada." ${ }^{362}$

Existem outros casos em que igualmente decidiu-se pela procedência da ação rescisória para prevalecer o valor justiça no caso concreto, não obstante não ter sido consignado expressamente tal escopo e, em muitos casos, até contra legem por não estarem presentes todos os requisitos da ação rescisória, o que deixa ainda mais evidente a proteção do valor justiça através da via rescisória, in verbis:

"I - Certidão de Casamento constando a profissão de lavrador do marido caracteriza documento novo capaz de atestar o início de prova material da atividade rurícola.

II - Nos termos da assentada jurisprudência da Corte, considerando as condições desiguais vivenciadas pelo trabalhador rural, e adotando a solução pro misero, a prova, ainda que preexistente à propositura da ação originária, deve ser considerada para efeito do art. 485 , VII, do CPC."

O que se verifica é que, nas hipóteses em que os tribunais superiores alegam não ser possível o exame da justiça da decisão por meio da ação rescisória, são casos de improcedência do pedido, por não restar caracterizada a violação à literal disposição de lei 364 .

Quanto ao error in procedendo existe interessante decisão do Superior Tribunal de Justiça, no sentido de que, alegada a sua existência na sentença, não há que se falar em substituição desta pelo acórdão proferido em grau de recurso, admitindo a

\footnotetext{
${ }^{362}$ STJ, REsp 562334/SP, rel. Min. José Delgado, DJ 19/12/03. Sintomático o entendimento lançado no citado acórdão que, até mesmo contra legem, vez que afirmou não se tratar de decisão de mérito, deu provimento à ação rescisória para aplicação da justiça ao caso concreto.

STJ, AR 904/SP, rel. Min. Gilson Dipp, DJ 04/08/03. No caso, evidente que certidão de casamento não poderia, a rigor, configurar documento novo nos termos do inciso VII, do art. 485, do CPC, pois não se pode afirmar que a parte ignorava sua existência ou existisse qualquer fato que justificasse a impossibilidade de sua utilização na demanda originária. Portanto, a rescisória, no caso em tela, foi julgada contra legem, ressaltando o caráter da necessidade de se fazer justiça no caso concreto. Existem outras várias decisões no mesmo sentido, destacando-se somente algumas exemplificadamente: AR 1415/MS, rel. Min. José Arnaldo da Fonseca, DJ 02/04/07; AR 1603/SP, rel. Min. Hamilton Carvalhido, DJ 04/08/03 e REsp 189306/MG, Min. p/ acórdão Cesar Asfor Rocha, DJ 14/10/02.

${ }^{364} \mathrm{Ou}$ a causa de pedir alegada pelo autor, mas, no mais das vezes, trata-se da hipótese do inciso V, do art. 485, CPC.
} 
rescisória contra a sentença e não o acórdão, por não ter se operado, na hipótese a substituição, verbis:

“- Quando for suscitado apenas "error in procedendo" no recurso de apelação, não há que se falar em substituição da sentença pelo acórdão prolatado no julgamento do recurso. Nesta hipótese, é viável apontar a sentença como objeto da ação rescisória."365

Em relação ao erro de fato propriamente dito, não existe muita controvérsia em sede jurisprudencial quanto aos pressupostos de seu cabimento, previstos nos parágrafos do inciso IX, do artigo 485 do Código de Processo Civil, destacando-se os seguintes casos em que os tribunais superiores têm entendido restar configurado o erro de fato para a ação rescisória: com relação aos reflexos civis da sentença penal, na hipótese de o acórdão cível ter entendido que não houve condenação na esfera penal por inexistência de autoria, quando, na verdade, a absolvição penal deu-se por ausência de provas suficientes da autoria 366 ; quando o acórdão rescindendo aplicou lei que não vigia à época dos fatos, quer porque a lei tinha sido revogada, quer porque os fatos eram anteriores à edição da lei 367 ; quando o acórdão rescindendo partiu de premissa errônea, pois pressupôs a inexistência de desconto das parcelas de seus empregados a titulo de vale-transporte, quando é incontroverso nos autos que tal fato ocorrera 368 ; se o acórdão rescindendo admitiu a prestação de serviço em determinada cidade, para incidência de certo imposto, quando na realidade esta não ocorreu naquela cidade 369 ; quando a decisão rescindenda aduz que a parte fazia jus a determinado expurgo inflacionário sobre os títulos da dívida pública que possuía, sem fazer a ressalva que tal expurgo só deveria incidir sobre os títulos emitidos em data anterior ao período de incidência da correção devida pelo expurgo 370 ; quando houver erro de digitação ou menção da data do fato e tal correção importe no reconhecimento ou afastamento da prescrição declarada ${ }^{371}$; se a decisão não considerou anotações na CTPS de atividades insalubres para cômputo do prazo de aposentadoria

${ }^{365}$ STJ, REsp 744271/DF, rel. Min. Nancy Andrighi, DJ 19/06/06.

${ }_{367}^{366}$ STJ, REsp 879734/RS, rel. Min. Maria Thereza De Assis Moura, DJe 18/10/10.

${ }^{367}$ STJ, AR 3718/SP, rel. Min. Felix Fischer, DJe 24/09/10; AR 3458/SE, rel. Min. Eliana Calmon, DJe 03/03/08 e AR 3276/SP, rel. Min. Laurita Vaz, DJ 18/02/08.

${ }^{368}$ STJ, AR 3394/RJ, rel. Min. Humberto Martins, DJe 22/09/10.

${ }^{369}$ STJ, AR 3945/GO, rel. Min. Herman Benjamin, DJe 30/06/10.

${ }^{370}$ STJ, AR 475/DF, rel. Min. Mauro Campbell Marques, DJe 15/03/10.

${ }^{371}$ STJ, AgRg no REsp 649353/PR, rel. Min. Luiz Fux, DJe 10/02/10 e AR 1620/SP, rel. Min. Humberto Gomes de Barros, DJ 08/03/06. 
especial $^{372}$; quando a decisão rescindenda proclama extinta a execução pela ocorrência de pagamento, mas este não foi integral 373 ; equívoco quanto a tempestividade recursal 374 ; decisão que atribui à autora objeto social inexistente em seu contrato social, para fins de incidência de determinado tributo 375 ; quando o acórdão rescindendo indeferiu determinado benefício previdenciário por entender inacumulável com outro benefício, quando, na realidade, no período pleiteado não havia dita cumulação 376 ; na hipótese em que a decisão rescindenda havia julgado procedente ação de rescisão contratual pela mora, quando os réus haviam purgado a mora no prazo da contestação 377 .

Existem, ainda, algumas decisões que consideram erro passível de ensejar ação rescisória a incorreta valoração da prova, o que, como se sabe, segundo os termos da lei, não pode ser causa para a ação rescisória por erro de fato. Porém, da leitura dos termos dos votos, transparece que, na realidade, não se trata de erro na valoração da prova, mas ausência de consideração de determinada prova (ausência de exame) no deslinde da questão. Neste sentido, é a seguinte decisão:

\begin{abstract}
"A $3^{\text {a }}$ Seção deste Superior Tribunal de Justiça tem considerado como erro de fato, a autorizar a procedência da ação rescisória com fundamento no artigo 485, inciso IX, do Código de Processo Civil, o erro na valoração da prova, consistente na desconsideração da prova constante nos autos, dadas as condições desiguais vivenciadas pelo trabalhador rural e adotando-se a solução pro misero."378 379
\end{abstract}

${ }^{372}$ STJ, REsp 762288/RS, rel. Min. Laurita Vaz, DJe 08/02/10.

${ }^{373}$ STJ, REsp 201486/SP, rel. Min. Franciulli Netto, DJ 04/04/05.

${ }^{374}$ STJ, REsp 562334/SP, rel. Min. José Delgado, DJ 31/05/04; AR 466/RJ, rel. Min. Ruy Rosado de Aguiar, DJ 06/05/96.

${ }^{375}$ STF, AR 1605/SP, rel. Min. Eros Grau, julgado em 26/03/09 e AR 1607/MS, rel. p/ acórdão Min. Eros Grau, julgado em 30/03/06.

${ }^{376}$ STF, AR 1311/SP, rel. Min. Moreira Alves, julgado em 22/03/91.

${ }^{377}$ STF, RE 106276/SP, rel. Min. Néri da Silveira, julgado em 30/06/88.

${ }^{378}$ STJ, AR 1335/CE, rel. Min. Hamilton Carvalhido, DJ 26/02/07. Como se vê, a decisão não é clara, pois ora fala em erro na valoração da prova, ora fala em desconsideração da prova constante nos autos. Neste mesmo sentido, com a mesma redação: AR 919/SP, rel. Min. Hamilton Carvalhido, DJ 05/03/07.

${ }^{379}$ Ainda no mesmo sentido, com pequena variação na redação da decisão: STJ, AR 2340/CE, rel. Min. Paulo Gallotti, DJ 12/12/05, com a seguinte ementa: "Reconhecendo-se o erro de fato com relação à valoração dos documentos existentes nos autos originais, mostra-se procedente o pedido rescisório, não se exigindo prova documental de todo o período trabalhado, demonstração operada com a ouvida de testemunhas." Efetivamente, no voto do Ministro Paulo Gallotti constou que houve erro na valoração da prova, porém, no voto da Ministra Laurita Vaz constou que houve erro de fato porquanto a decisão rescindenda julgou inexistente prova que existia. Também no mesmo sentido: AR 1240/SP, rel. Min. Laurita Vaz, DJ 25/06/07. 
De outra parte, os tribunais superiores entendem não ter havido erro de fato: alegação de incorreta aplicação de súmula ao caso concreto 380 ; a atribuição de nova qualificação jurídica a compromisso firmado entre as partes ${ }^{381}$; quando a sentença decreta a revelia e admite como verdadeiros os fatos articulados pelo autor 382 ; o incorreto valor da taxa de determinado índice de correção monetária em certo mês, por ser erro material e não erro de fato 383 ; quando a matéria decidida na ação rescindenda for "exclusivamente de direito"384; irregularidade na representação processual da parte, por ausência de procuração ao advogado 385 e erro na fundamentação da decisão rescindenda, evidenciando que se aplica a outra demanda, não à causa decidida 386 .

Em relação ao erro de direito, as controvérsias jurisprudenciais são mais numerosas e maior é o número de questões enfrentadas. $\mathrm{O}$ primeiro ponto que impende destacar é em relação ao entendimento de em que consistiria a "literal violação de lei". Diversamente do entendimento doutrinário, a jurisprudência é maciça no sentido de afirmar que a violação, para caracterizar a hipótese do inciso V, do artigo 485, do Código de Processo Civil, deve ser frontal, atentar contra a literalidade da norma, usando-se expressões como interpretação "aberrante", "esdrúxula", "extravagante"387.

Neste sentido, cabe transcrever a seguinte ementa para ilustrar o entendimento jurisprudencial:

"É cediço na Corte que "para que a ação rescisória fundada no art. 485 , $\mathrm{V}$, do CPC, prospere, é necessário que a interpretação dada pelo decisum rescindendo seja de tal modo aberrante que viole o dispositivo legal em sua literalidade. Se, ao contrário, o acórdão rescindendo elege uma dentre as interpretações cabíveis, ainda que não seja a melhor, a ação rescisória

${ }^{380}$ STJ, AgRg na AR 4367/PR, rel. Min. Castro Meira, DJe 06/04/10.

${ }^{381}$ STJ, AR 701/SP, rel. Min. Ari Pargendler, DJ 22/05/06.

${ }^{382}$ STJ, REsp 472777/PA, rel. Min. Carlos Alberto Menezes Direito, DJ 20/10/03.

${ }^{383}$ STJ, AR 630/DF, rel. Min. Francisco Falcão, DJ 26/05/03.

${ }^{384}$ STJ, AR 590/DF, rel. Min. Ari Pargendler, DJ 15/06/98. Apesar de ter constado na ementa não ser possível a verificação de erro de fato em matéria "exclusivamente de direito" (afirmação com a qual não concordamos, pois mesmo nas demandas que versam sobre questões exclusivamente de direito, existe um suporte fático que as embasa, que podem não ser controvertidos, mas fato sempre há), no voto restou consignado que não se trata de erro de fato, mas de mero erro aritmético, relativo à taxa da correção monetária aplicável à espécie.

${ }^{385}$ STJ, AgRg nos EDcl na AR 2940/PR, rel. Min. Nancy Andrighi, DJ 02/02/04.

${ }_{387}^{386}$ STF, AR 1646/SC, rel. Min. Marco Aurélio, julgado em 27/09/06.

${ }^{387}$ Neste sentido: STJ, REsp 954720/RJ, rel. Min. Luiz Fux, DJe 08/10/10; EDcl no REsp 1104196/RN, rel. Min. João Otávio de Noronha, DJe 02/09/10; AR 3104/RS, rel. Min. Hamilton Carvalhido, DJe 16/04/10; AR 3225/MS, rel. Min. Vasco Della Giustina, DJe 03/02/10; AgRg na AR 3427/PA, rel. Min. Vasco Della Giustina, DJe 19/05/09 e AR 464/RJ, rel. Min. Barros Monteiro, DJ 19/12/03; 
não merece vingar, sob pena de tornar-se 'recurso' ordinário com prazo de interposição de dois anos [...].

A doutrina encampa referido entendimento ao assentar, verbis: "(...) a causa de rescindibilidade reclama 'violação' à lei; por isso, 'interpretar' não é violar. Ainda é atual como fonte informativa que tem sido utilizada pela jurisprudência, a enunciação do CPC de 1939, no seu artigo 800, caput: 'A injustiça da sentença e a má apreciação da prova ou errônea interpretação do contrato não autorizam o exercício da ação rescisória'. Ademais, para que a ação fundada no art. 485, V, do CPC, seja acolhida, é necessário que a interpretação dada pelo decisum rescindendo seja de tal modo teratológica que viole o dispositivo legal em sua literalidade. Ao revés, se a decisão rescindenda elege uma dentre as interpretações cabíveis, a ação rescisória não merece prosperar. [...]”388

De fato, a única decisão em sentido contrário à orientação anteriormente expendida é a constante do REsp 640/SP, relatado pelo Ministro Milton Luiz Pereira, publicado em 15/02/93, in verbis:

\begin{abstract}
"A ação rescisória, diante de objetivas circunstancias da ordem social e econômica, liberta a interpretação construtiva da norma legal na aplicação dinâmica do direito, não se constituindo como instrumento restrito só ao exame de literal violação a disposição de lei, escravizando a ordem jurídica ao formalismo impiedoso ou tecnicista."
\end{abstract}

$\mathrm{Na}$ esteira do entendimento predominante da orientação jurisprudencial, algumas decisões entendem que, não tendo sido suscitada a matéria tida por violada no acórdão rescindendo, não houve violação à sua disposição literal ${ }^{389}$, construção totalmente equivocada. Entendimento contrário consta no seguinte aresto 390 :

"Cabível a desconstituição, pela via rescisória, de decisão com trânsito em julgado que "deixa de aplicar uma lei por considerá-la inconstitucional ou a aplica por tê-la como de acordo com a Carta Magna."

No que tange ao entendimento à abrangência da expressão "lei" há entendimento no sentido de entender admissível a ação rescisória com fulcro no inciso $\mathrm{V}$, do artigo 485 do Código de Processo Civil, quando a decisão rescindenda contrariar

\footnotetext{
${ }^{388}$ STJ, AR 1386/MG, rel. Min. Luiz Fux, DJe 01/07/09.

${ }^{389}$ STJ, AR 3001/MG, rel. Min. Laurita Vaz, DJ 01/02/08.

${ }^{390}$ STJ, AR 870/PE, rel. Min. José Arnaldo da Fonseca, DJ 13/03/00.
} 
princípio não escrito ${ }^{391}$. Nesse aspecto, ainda, existe orientação contrária à viabilidade da ação rescisória com base em divergência jurisprudencial 392.

Outro ponto que suscita dúvidas e levantou acalorada discussão jurisprudencial, refere-se à aplicabilidade da súmula 343 quando não se tratar de violação à norma constitucional. Com efeito, a jurisprudência é pacífica no sentido de afastar a aplicação da súmula 343 nas hipóteses que envolvem matéria constitucional ${ }^{393}$, fazendo a súmula incidir nas demais hipóteses. Porém, recentemente, o Ministro Teori Albino Zavascki proferiu entendimento no sentido de se afastar o verbete contido na mencionada súmula nos casos de violação à lei federal, propondo, inclusive, a revisão da dita súmula, com base nos fundamentos sintetizados na seguinte ementa:

\section{"PROCESSUAL CIVIL. AÇÃO RESCISÓRIA. VIOLAÇÃO À LEI FEDERAL. MATÉRIA CONTROVERTIDA NOS TRIBUNAIS À ÉPOCA DA PROLAÇÃO DA DECISÃO RESCINDENDA. JURISPRUDÊNCIA DO STJ EM SENTIDO CONTRÁRIO. SÚMULA 343/STF. NÃO-APLICAÇÃO. REVISÃO DA JURISPRUDÊNCIA A RESPEITO.}

1. A súmula 343/STF, editada antes da Constituição de 1988 , tem origem na doutrina (largamente adotada à época, inspiradora também da súmula 400/STF) da legitimidade de interpretação razoável da norma, ainda que não a melhor, permitindo assim que a respeito de um mesmo preceito normativo possa existir mais de uma interpretação e, portanto, mais de um modo de aplicação.

2. Ao criar o STJ e lhe dar a função essencial de guardião e intérprete oficial da legislação federal, a Constituição impôs ao Tribunal o dever de manter a integridade do sistema normativo, a uniformidade de sua interpretação e a isonomia na sua aplicação. $O$ exercício dessa função se mostra particularmente necessário quando a norma federal enseja divergência interpretativa. Mesmo que sejam razoáveis as interpretações divergentes atribuídas por outros tribunais, cumpre ao STJ intervir no sentido de dirimir a divergência, fazendo prevalecer a sua própria interpretação. Admitir interpretação razoável, mas contrária à sua própria, significaria, por parte do Tribunal, renúncia à condição de intérprete institucional da lei federal e de guardião da sua observância.

3. Por outro lado, a força normativa do princípio constitucional da isonomia impõe ao Judiciário, e ao STJ particularmente, o dever de dar tratamento jurisdicional igual para situações iguais. Embora possa não atingir a dimensão de gravidade que teria se decorresse da aplicação antiisonômica da norma constitucional, é certo que o descaso à isonomia em face da lei federal não deixa de ser um fenômeno também muito grave e igualmente ofensivo à Constituição. Os efeitos da ofensa ao princípio da

\footnotetext{
${ }^{391}$ No caso, da vedação à reformatio in peius, SJT, AR 3031/DF, rel. Min. Mauro Campbell Marques, DJe 15/03/10.

${ }^{392}$

STJ, REsp 151845/CE, rel. Min. Franciulli Netto, DJ 19/02/01.

${ }^{393}$ V.g., STJ, AR 3382/PR, rel. Min. Arnaldo Esteves Lima, DJe 02/08/10.
} 
igualdade se manifestam de modo especialmente nocivos em sentenças sobre relações jurídicas de trato continuado: considerada a eficácia prospectiva inerente a essas sentenças, em lugar da igualdade, é a desigualdade que, em casos tais, assume caráter de estabilidade e de continuidade, criando situações discriminatórias permanentes, absolutamente intoleráveis inclusive sob o aspecto social e econômico. Ora, a súmula 343 e a doutrina da tolerância da interpretação razoável nela consagrada têm como resultado necessário a convivência simultânea de duas (ou até mais) interpretações diferentes para o mesmo preceito normativo e, portanto, a cristalização de tratamento diferente para situações iguais. Ela impõe que o Judiciário abra mão, em nome do princípio da segurança, do princípio constitucional da isonomia, bem como que o STJ, em nome daquele princípio, também abra mão de sua função nomofilácica e uniformizadora e permita que, objetivamente, fique comprometido o princípio constitucional da igualdade.

4. É relevante considerar também que a doutrina da tolerância da interpretação razoável, mas contrária à orientação do STJ, está na contramão do movimento evolutivo do direito brasileiro, que caminha no sentido de realçar cada vez mais a força vinculante dos precedentes dos Tribunais Superiores.

5. Por todas essas razões e a exemplo do que ocorreu no STF em matéria constitucional, justifica-se a mudança de orientação em relação à súmula 343/STF, para o efeito de considerar como ofensiva a literal disposição de lei federal, em ação rescisória, qualquer interpretação contrária à que lhe atribui o STJ, seu intérprete institucional. A existência de interpretações divergentes da norma federal, antes de inibir a intervenção do STJ (como recomenda a súmula), deve, na verdade, ser o móvel propulsor para o exercício do seu papel de uniformização. Se a divergência interpretativa é no âmbito de tribunais locais, não pode o STJ se furtar à oportunidade, propiciada pela ação rescisória, de dirimi-la, dando à norma a interpretação adequada e firmando o precedente a ser observado; se a divergência for no âmbito do próprio STJ, a ação rescisória será o oportuno instrumento para uniformização interna; e se a divergência for entre tribunal local e o STJ, o afastamento da súmula 343 será a via para fazer prevalecer a interpretação assentada nos precedentes da Corte Superior, reafirmando, desse modo, a sua função constitucional de guardião da lei federal.

6. Recurso especial provido.",394

A questão foi pacificada por ocasião do julgamento da AR 3525/DF, relatada pela Ministra Eliana Calmon, publicada no DJe de 04/05/09, em que a primeira seção do Superior Tribunal de Justiça firmou entendimento no sentido da validade e aplicabilidade da súmula 343 nas matérias que não envolvem questão constitucional, ficando vencidos os Ministros Teori Albino Zavascki, Ministra Denise Arruda e Ministro Herman Benjamin, sagrando-se vencedora tese em sentido contrário. Tanto é assim que, nos Embargos de

\footnotetext{
${ }^{394}$ STJ, REsp 1026234/DF, DJe 11/06/08. De igual teor, 1.063.310, DJe 20/08/08.
} 
Divergência opostos contra a decisão anteriormente transcrita ${ }^{395}$, a decisão foi reformada, por unanimidade, contando inclusive com o voto do Ministro Teori Albino Zavascki, que se rendeu à maioria, aplicando-se a súmula 343 para o caso em tela.

Ainda em relação à súmula 343, existe decisão entendendo que, a divergência existente somente em um tribunal não é suficiência para caracterizar a divergência de opiniões $^{396}$, assim como se a divergência se restringir ao âmbito do próprio Superior Tribunal de Justiça 397 .

${ }^{395}$ Bem como da decisão proferida no outro acórdão de igual teor, 1.063.310.

${ }^{396}$ STJ, REsp 253194/RS, rel. Min. Garcia Vieira, DJ 14/08/00.

${ }^{397}$ STJ, AR 975/RS, rel. Min. Maria Thereza de Assis Moura, DJe 12/11/08. 


\section{CONCLUSÕES}

De todo o exposto ao longo do presente trabalho, permite-se adotar as seguintes conclusões que mais interessam ao tema em exame:

1. Dentre os escopos da prestação jurisdicional prestada em monopólio pelo Estado, insere-se o escopo social, que pode ser sintetizado pela eliminação dos conflitos mediante critérios justos, demonstrando a válida preocupação do processo (meio predisposto à eliminação dos conflitos) com critérios éticos e de equidade;

2. Juntamente com o valor da justiça, encontra-se, em paralelo, o valor da segurança das decisões, a fim de que o instrumento produza seus resultados esperados de pacificação social;

3. O critério de "justiça das decisões" varia de acordo com os valores vigentes na época e local em que a decisão é proferida, sendo o processo, e assim, a decisão que ele produz, resultado desses valores;

4. O sistema dispõe de mecanismos pré-estabelecidos para propiciar os resultados desejados e, para que se alcance a segurança jurídica, a coisa julgada desempenha papel fundamental no nosso ordenamento, assegurando a imutabilidade e intangibilidade dos efeitos da sentença de mérito, que põe fim, de maneira definitiva, ao litígio;

5. A coisa julgada possui caráter público, não só por se tratar de uma opção legislativa, como também por ser ela ponto central do nosso sistema jurídico, não podendo as partes, terceiros ou o próprio Estado, desconstituí-la senão dentro dos limites e observados determinados e rígidos pressupostos estabelecidos em lei;

6. É imperioso estabelecer-se os limites da coisa julgada, tanto subjetivos como objetivos, a fim de se verificar, posteriormente, quais os legitimados para a ação rescisória (pertinente aos limites subjetivos da coisa julgada - pois, só aqueles atingidos por ela é que se habilitaram a desfazê-la), bem como sobre qual objeto poderá versar a ação rescisória (pois somente aquilo que ficar encoberto pela coisa julgada poderá ser igualmente objeto da ação rescisória);

7. Os sistemas jurídicos, de um modo geral, preveem meios hábeis à revisão das decisões judiciais, não só para satisfação de uma necessidade inerente à condição 
humana de expressar a sua insatisfação diante de uma situação adversa (conferindo, assim, maior legitimidade às suas decisões), como também para propiciar maior segurança ao sistema como um todo. Tais mecanismos são os meios de impugnação das decisões judiciais;

8. A doutrina nacional costuma classificar os meios de impugnação entre os recursos, os quais são manifestados dentro do mesmo processo e relação processual em que proferida a decisão impugnada, e as ações autônomas, que criam um novo processo e relação processual diverso do qual a decisão impugnada foi proferida;

9. Podemos dizer, ainda, que existem os meios típicos ou ordinários de impugnação das decisões, que visam impugnar decisões que não estão revestidas da coisa julgada, e os meios atípicos ou excepcionais, que visam atacar as decisões já cobertas pela garantia da coisa julgada. Insere-se nos segundos, a ação rescisória;

10. Justamente por atacar as decisões acobertadas pela autorictas rei judicatae é que a ação rescisória é vista como um meio excepcional, só cabível nos casos expressa e taxativamente previstos em lei (mais precisamente, nos incisos do artigo 485 do Código de Processo Civil);

11. Nessa medida, a ação rescisória está intimamente ligada ao escopo social do processo, pois visa resguardar o valor da justiça das decisões, uma vez que, diante da existência de vícios de natureza tão graves, previamente eleitos pelo legislador, permite-se a revisão da decisão revestida pela coisa julgada;

12. Através da ação rescisória exerce-se um duplo juízo sobre a decisão, chamados de juízo rescindendo, no qual se verifica a existência do vício alegado e, caso existente, desconstitui-se a decisão rescindenda, e de juízo rescisório, através do qual, se necessário, profere-se novo julgamento sobre a causa;

13. Conforme expressa determinação legal, o objeto da ação rescisória será sempre uma sentença de mérito transitada em julgado;

14. Deve-se atribuir um sentido mais amplo à expressão sentença, estando aí incluída qualquer decisão que decida o mérito da causa;

15. O vício que macula a decisão rescindenda não precisar dizer respeito ao mérito, mas somente a decisão rescindenda é que precisa ser de mérito; 
16. A primeira dificuldade que se enfrenta em relação ao tema, é quanto à identificação e à possibilidade da cisão formal da sentença de mérito, especialmente tendo em vista as recentes alterações legislativas levadas a efeito pela Lei n. 11.232/05, no que tange à identificação da sentença de mérito, em razão da modificação implementada no artigo 162 do Código de Processo Civil;

17. Contudo, não se deve entender que as alterações implementadas pela retro referida lei introduziram, nesse aspecto, qualquer alteração de substância. Com efeito, não se pode admitir a existência de várias sentenças de mérito ao longo do processo, que resolvam parcialmente a lide, por diversas razões, tanto de ordem histórica, como em razão de interpretação sistemática do Código, pois não há previsão para o recurso a ser interposto dessa eventual sentença “interlocutória”;

18. Ademais, pelo princípio da unicidade da sentença, não se permite a cisão formal da mesma;

19. Nesse aspecto, ainda é de grande relevo a diferenciação entre mérito e questões de mérito, sendo a primeira o objeto do processo, o bem da vida pleiteado pelo autor e as segundas, questões que são antecedentes lógicos à resolução do mérito. Ambas devem ser abordadas na sentença (art. 458, II, do CPC), sob pena de existirem decisões interlocutórias que tratem de questões atinentes ao mérito (o exemplo mais comum é o do afastamento da prescrição), de modo inapropriado;

20. Outra questão que suscita dúvidas na doutrina e na jurisprudência diz respeito às possíveis decisões que contenham mérito, e assim, sejam passíveis de desconstituição por meio da ação rescisória. Parece que ambos estão concordes em que, qualquer decisão que, própria ou inapropriadamente, decida o mérito, é passível de ser cassada pela via rescisória;

21. O problema que surge consiste na identificação das decisões que, de modo impróprio, decidem o mérito. O critério que nos parece mais adequado é verificar se a decisão produziu efeitos sobre a relação substancial, ou seja, sobre o bem da vida, de modo definitivo, não sendo mais possível alterá-las pelas vias ordinárias ou típicas;

22. Traçando um paralelo entre o erro no direito material e no direito processual, que abre ensejo à ação rescisória, não se pode adotar, de modo proveitoso, os conceitos e as premissas existentes no direito substancial para o direito processual; 
23. É curial que o erro de fato seja atribuível ao julgador, não se podendo falar em erro das partes, sendo resultado de sua desatenção no exame dos autos;

24. É corrente na doutrina e na jurisprudência que a ação rescisória não se presta ao exame da "justiça das decisões". Tal se deve, muito provavelmente, em razão da redação do artigo 800 do Código de Processo Civil de 39, que dispunha que a injustiça da sentença e a má apreciação da prova ou errônea interpretação do contrato não autorizavam o exercício da ação rescisória;

25. Todavia, não se pode adotar simplesmente referido conceito, sem ressalvas. De fato, a ação rescisória não se presta, pura e simplesmente, à apreciação da "justiça das decisões”, porém, é inegável que a ação rescisória se liga umbilicalmente ao valor justiça, ou seja, ao escopo social do processo, acabando por realizar justiça ao caso concreto, eliminando a decisão viciada que anteriormente havia sido produzida pelo Estado, a fim de que uma nova, isenta dos vícios alegados (perniciosos e previamente eleitos pelo sistema), seja proferida;

26. Aplica-se à ação rescisória o princípio iura novit curia, não importando que a parte tenha eventualmente indicado incorretamente o inciso do artigo 485 do Código de Processo Civil em que a sua ação rescisória se funda, ou seja, a qualificação jurídica que tenha atribuído aos fatos, desde que os tenha narrado adequadamente;

27. O erro de fato para a ação rescisória, tal como consta no inciso IX, do artigo 485 do Código de Processo Civil teve por inspiração o artigo 395, $n^{0} 4$, do Código de Processo Civil italiano.

28. No entanto, ao proceder à tradução do referido artigo, o legislador nacional cometeu alguns equívocos, que acabaram por gerar certa perplexidade e até mesmo, incongruências no nosso sistema;

29. O primeiro equívoco mais comumente apontado pela doutrina, diz respeito às expressões "risultanti" e "atti", traduzidas como resultantes e atos. Todavia, "risultanti", seria melhor traduzida por, que transparece, que emerge, que ressalta e "atti" está utilizada no texto original por autos, não atos, como equivocadamente fez o legislador pátrio. $\mathrm{O}$ outro equívoco de tradução não foi percebido pela maioria dos doutrinadores pátrios, diz respeito aos pressupostos da ação rescisória por erro de fato, causando certa perplexidade e contradição na nossa legislação, acarretando, inclusive, consequências de ordem prática, que se verificam na jurisprudência; 
30. Quanto aos pressupostos para a ação rescisória por erro de fato, a doutrina nacional costuma apontar os seguintes: nexo de causalidade, que o erro seja aparente, ausência de controvérsia e ausência de pronunciamento judicial sobre o fato;

31. O nexo de causalidade se determina pela existência de uma relação de causalidade entre o erro e o provimento, no sentido de que, eliminado o erro, cai por terra o pressuposto sobre o qual se funda a decisão;

32. O erro que pode abrir a via rescisória por erro de fato deve resultar de forma irrefutável dos autos e documentos da causa, sendo evidente, não necessitando de maiores argumentações indutivas ou indagações hermenêuticas;

33. A ausência de controvérsia sobre o fato é outra exigência legal para que se abra caminho à via rescisória com base em erro de fato, não se admitindo esta, mesmo que a controvérsia tenha se dado somente entre as partes, restando silente a decisão a respeito. Parece que este é um ponto pacífico na nossa doutrina e jurisprudência;

34. Porém, de lege ferenda, não nos parece que tal critério seja adequado para viabilização da ação rescisória, pois, caso tenha havido a controvérsia entre as partes e o órgão julgador, ainda assim, não se manifestar a respeito, terá incidido em erro da mesma forma, não nos parecendo correto excluir a ação rescisória somente porque as partes tenham controvertido a respeito do fato. A se pensar assim, estar-se-á prejudicando a parte diligente, que ressaltou ponto que entendia lhe ser favorável, bem como aquela que repeliu a questão suscitada pela outra parte. Somente aqueles que não tenham se manifestado a respeito poderão fazer uso da ação rescisória, premiando-se (ou, ao menos, conferindo maior possibilidade) àquele que agir com desídia, o que nos parece um contra-senso;

35. Tal raciocínio se mostra válido tendo em vista que, como observado, o erro que importa para a ação rescisória é o erro do juiz e não o erro da parte e, na medida em que, não obstante tiver havido controvérsia sobre a questão somente entre as partes, terá havido, da mesma forma, erro do julgador;

36. O raciocínio acima somente não se aplicaria caso se permita, na hipótese acima aventada, que a parte prejudicada possa se valer da ação rescisória por erro de direito (violação à literal disposição de lei, por não ter a decisão solucionado questão suscitada pelas partes, contrariando o disposto no artigo 485, II e III do Código de Processo Civil), o que não poderá ser óbice para o conhecimento da rescisória, pois em razão da incidência do princípio da iura novit curia, eventual indicação incorreta do inciso 
em que se funda a ação (na hipótese, IX por V) não impedirá o seu trânsito. Ocorre que, em tais casos, nem sempre será possível a rescisória com base em erro de direito;

37. O pressuposto que rende maiores perplexidades e controvérsias na ação rescisória por erro de fato é o requisito da ausência de pronunciamento judicial sobre $o$ fato. Ora, se o juiz errou, afirmando existente fato que não se verificou ou afirmando inexistente fato que efetivamente ocorreu, como poderá haver ausência de pronunciamento judicial? Trata-se de verdadeira contradição;

38. A questão deve ser solucionada à luz da legislação que inspirou o instituto em tela, pois, no direito italiano, não se exige ausência de pronunciamento sobre o fato, mas sobre a controvérsia, tendo o legislador pátrio novamente incidido em erro na tradução do original, que dispõe: “...tanto nell'uno quanto nell'altro caso se il fatto non costitui' un punto controverso sul quale la sentenza ebbe a pronunciare".

39. Ou seja, o que se exige é que o fato não constitua um ponto controverso sobre o qual a sentença tenha se pronunciado. Na realidade não são duas exigências feitas pela legislação italiana (ausência de controvérsia $e$ de pronunciamento), mas uma só, que se resume na ausência de controvérsia sobre um ponto a respeito de que a sentença teve que se pronunciar.

40. Tanto é assim que, em razão do equívoco na tradução, este é um dos pontos que desperta maior polêmica na doutrina nacional, mas, tanto na doutrina italiana como na jurisprudência não há qualquer manifestação a respeito, sendo ambos tratados como um único pressuposto: ausência de controvérsia sobre a qual a sentença teve que se pronunciar. Este é o entendimento que deve ser atribuído à norma em questão;

41. A doutrina italiana controverte muito, ainda, sobre a qualificação e identificação do erro passível de ensejar a ação rescisória, discussão praticamente inexistente entre nós;

42. O erro de direito, na forma como abordado no presente trabalho, é só aquele relativo à hipótese do inciso $\mathrm{V}$, do artigo 485 do Código de Processo Civil, ou seja, por violação à literal disposição de lei;

43. Nessa hipótese não se faz necessário o prequestionamento da norma no processo em que proferida a decisão rescindenda; 
44. Para que seja possível a ação rescisória por erro de direito, não é necessário nem que a norma seja clara, nem que a violação se dê contra a literalidade da norma, pois, dificilmente um órgão julgador irá contrariar uma norma de forma clara e frontal, geralmente usa de subterfúgios e raciocínios equivocados para justificar o seu posicionamento, que se revela contrário à norma;

45. Deve-se dar a maior abrangência possível ao termo "lei" constante no texto legal, entendendo-se esta como o direito, o sistema vigente, estando aí compreendidos os princípios, a analogia e os costumes, não havendo necessidade, portanto, de que a norma seja escrita;

46. A partir da edição da EC 45/2004, que criou a súmula vinculante, tendo esta caráter de norma geral e abstrata e de cunho vinculativo, deve-se admitir também a via rescisória com fundamento no erro de direito, também por violação à dita súmula;

47. O erro de direito pode se dar tanto em relação ao error in procedendo (violação ao direito processual), como em relação ao error in iudicando (violação à norma de direito substancial);

48. De acordo com a Súmula 343/STF, "não cabe ação rescisória por ofensa à literal disposição de lei, quando a decisão rescindenda se tiver baseado em texto legal de interpretação controvertida nos tribunais". Contudo, tanto o Supremo Tribunal Federal como o Superior Tribunal de Justiça não aplicam o texto da citada súmula quando se tratar de questão constitucional.

49. A referida súmula sofreu sérias críticas da doutrina, que entende que essa contraria o princípio da igualdade e da legalidade. Houve um movimento jurisprudencial, capitaneado principalmente pelo Ministro Teori Albino Zavascki, no sentido de se proceder à revisão da mencionada súmula, especialmente tendo em vista as atribuições do Superior Tribunal de Justiça que deve zelar pelas normas federais. O Ministro afirmara que, assim como o Supremo Tribunal Federal não aplica a súmula para as questões que envolvem norma constitucional, o Superior Tribunal de Justiça deveria, igualmente, afastar a incidência da súmula em questão, quando se tratar de norma federal. Contudo, seu posicionamento foi vencido, consolidando-se a opinião pela manutenção da súmula, quando não se cuidar de questão constitucional;

50. Impende ressaltar que, tanto o erro material quanto o erro de cálculo não são passíveis de correção por meio da ação rescisória, pois não visam a alteração da coisa 
julgada, podendo ser corrigidos, portanto, de ofício ou a requerimento da parte 398 , mesmo após o trânsito em julgado;

51. Não se inclui no erro de cálculo o equívoco nos critérios estabelecidos para apuração do valor devido, mas somente os erros aritméticos;

52. Diversamente do erro de fato, em que não pode haver controvérsia entre as partes sobre o fato, para o erro de direito é indiferente se houve ou não discussão acerca da norma tida por violada;

53. Tendo em vista a apresentação do anteprojeto de Código de Processo Civil pela comissão de juristas instituída para tanto, e considerando-se as conclusões ora apresentadas, elaboramos uma despretensiosa proposta para alteração do texto do anteprojeto, a respeito da ação rescisória, a saber:

Anteprojeto:

“Art. 884. A sentença ou o acórdão de mérito, transitados em julgado, podem ser rescindidos quando: [...]

$\mathrm{V}$ - violarem manifestamente a norma jurídica;

$[\ldots]$

VIII - fundada em erro de fato verificável do exame dos autos.

Parágrafo único: Há erro quando a decisão rescindenda admitir um fato inexistente ou quando considerar inexistente um fato efetivamente ocorrido, sendo indispensável, num como noutro caso, que não tenha havido controvérsia, nem pronunciamento judicial sobre o fato."399

Sugestão de redação proposta:

Art. 884. As decisões de mérito, transitadas em julgado, podem ser rescindidas quando: [...]

V - violarem norma jurídica, não sendo possível a revisão dos fatos para a verificação da violação;

$[\ldots]$

VIII - fundadas em erro de fato verificável do exame dos autos.

Parágrafo primeiro: Há erro de fato quando a decisão rescindenda admitir um fato inexistente ou quando considerar inexistente um fato efetivamente ocorrido, por desatenção na verificação dos documentos e atos dos autos;

Parágrafo segundo: Não constitui erro de fato a equívoca valoração da prova.

\footnotetext{
${ }^{398}$ Art. 463, I, do CPC.

${ }^{399}$ Referido artigo passou a ser o art. 919 após a aprovação pelo Plenário do Senado.
} 


\section{REFERÊNCIAS BIBLIOGRÁFICAS}

ALESSIO, Giovanni. La revocazione delle sentenze civili. Napoli: Nicola Jovene, 1888.

AMERICANO, Jorge. Da acção rescisoria dos julgados no direito brasileiro. São Paulo: Casa Vanorden, 1922.

ANDRIOLI, Virgilio. Commento al codice di procedura civile. Napoli: E. Jovene, 1960. v. 2.

ARAGÃO, Egas Dirceu Moniz de. Sentença e coisa julgada. São Paulo: Aide, 1992.

ASSIS, Araken de. Manual da execução. São Paulo: Ed. Revista dos Tribunais, 2009. . Manual dos recursos. São Paulo: Ed. Revista dos Tribunais, 2007.

AZEVEDO, Luiz Carlos de; COSTA, Moacyr Lobo da. Estudos de história do processo: recursos. Osasco: FIEO, 1996.

BARBOSA MOREIRA, José Carlos. As bases do direito processual civil. In:

Temas de direito processual: (primeira série). São Paulo: Saraiva, 1988. p. 3-15.

. Coisa julgada e declaração. In: Temas de direito processual: (primeira série). São Paulo: Saraiva, 1988. p. 81-89.

. Comentários ao Código de Processo Civil. Rio de Janeiro: Forense, 2008. v. 5.

. Considerações sobre a chamada "relativização" da coisa julgada material. In:

. Temas de direito processual: (nona série). São Paulo: Saraiva, 2007. p. 235-265.

. Considerações sobre a causa de pedir na ação rescisória. In: Temas de direito processual: $4^{\mathrm{a}}$ série. São Paulo: Saraiva, 1988.

A eficácia preclusiva da coisa julgada material no sistema do processo civil brasileiro. In: . Temas de direito processual: (primeira série), São Paulo: Saraiva, 1988. p. 97-109.

O juízo de admissibilidade no sistema dos recursos civis. 1968. Tese (LivreDocência) - Faculdade de Direito da Universidade do Estado da Guanabara. Rio de Janeiro, 1968. 
BARBOSA MOREIRA, José Carlos. Os limites objetivos da coisa julgada no sistema do novo código de processo civil, In: Temas de direito processual: (primeira série), São Paulo: Saraiva, 1988. p. 90-96.

- A nova definição de sentença. In: Temas de direito processual: (nona série). São Paulo: Saraiva, 2007.

BEDAQUE, José Roberto dos Santos. Direito e processo: influência do direito material sobre o processo. São Paulo: Malheiros Ed., 2003.

Efetividade do processo e técnica processual. São Paulo: Malheiros Ed., 2007.

BRASIL. Congresso nacional. Senado federal. Comissão de juristas responsável pela elaboração de Anteprojeto de Código de Processo Civil. Código de processo civil: anteprojeto, Brasília: Senado Federal, 2010.

CALAMANDREI, Piero. La cassazione civile. Torino: Fratelli Bocca: Italian Book Co., 1920.

CANOTIlHO, J. J. Gomes. Direito constitucional e teoria da constituição. 4. ed. Coimbra: Almedina.

CARNEIRO, Athos Gusmão. Cumprimento da sentença civil. Rio de Janeiro: Forense, 2007.

CARPI, Federico; TARUFFO, Michele. Commentario breve al codice di procedura civile. Padova: Cedam, 2002.

CAZETTA JÚNIOR, José Jesus. Conteúdo da causa de pedir e proposta de aplicação dessa categoria ao recurso extraordinário: um exame crítico. In: CRUZ E TUCCI, José Rogério; BEDAQUE, José Roberto dos Santos (Coords.). Causa de pedir e pedido no processo civil: (questões polêmicas). São Paulo: Ed. Revista dos Tribunais, 2002.

CHIOVENDA, Giuseppe. Instituições de direito processual civil. Tradução da 2. ed., por Paolo Capitano. Campinas: Bookseller, 2000. v. 1.

Instituições de direito processual civil. Tradução da 2. ed., por J. Guimarães Menegale. São Paulo: Saraiva, 1965. v. 3.

CINTRA, Antonio Carlos de Araujo; GRINOVER, Ada Pellegrini; DINAMARCO, Cândido Rangel. Teoria geral do processo. São Paulo: Ed. Revista dos Tribunais, 1990. 
COLESANTI, Vittorio. Sentenza civile (revocazione della). In: AZARA, Antonio; EULA, Ernesto (Coords.). Novissimo digesto italiano. Torino: Torinese, 1957.

COMOGLIO, Luigi Paolo; FERRI, Corrado; TARUFFO, Michele. Lezioni sul processo civile. Bologna: Il Mulino, 1998.

COSTA, Coquejo. Ação rescisória. São Paulo: LTr, 1982.

COSTA, Moacyr Lobo da Cumulação de juízos na ação rescisória. São Paulo: [s.n.], 1986.

. A revogação da sentença: gênese e genealogia. São Paulo: Ícone, 1995.

_. Revogação da sentença na península hibérica: perfil histórico. São Paulo [S.N.], 1979.

COSTA, Susana Henriques da. Condições da ação. São Paulo: Quartier Latin do Brasil, 2005 .

COUTURE, Eduardo J. Fundamentos do direito processual civil. Trad. Rubens Gomes de Sousa. São Paulo: Saraiva, 1946.

Introdução ao estudo do processo civil. trad. Mozart Victor Russomano. Rio de Janeiro: Jose Konfino, 1951.

CRUZ E TUCCI, José Rogério. A causa petendi na ação rescisória. Revista Forense, ano 93, v. 339, p. 109-112, jul./set. 1997.

A causa petendi no processo civil. São Paulo: Ed. Revista dos Tribunais, 2001.

Limites subjetivos da eficácia da sentença e da coisa julgada civil. São Paulo: Ed. Revista dos Tribunais, 2006.

; AZEVEDO, Luiz Carlos. Lições de história do processo civil romano. São Paulo: Revista dos Tribunais, 1996.

DINAMARCO, Cândido Rangel. Ação rescisória, incompetência e carência de ação. Revista de Processo, ano 26, n. 104, p. 11-19, out./dez. 2001.

_ Capítulos de sentença. São Paulo: Malheiros, 2009. . Execução civil. 5. ed. São Paulo: Malheiros Ed., 1997.

. Fundamentos do processo civil moderno. São Paulo: Malheiros Ed., 2002. v. 2. . Nova era do processo civil. São Paulo: Malheiros Ed., 2003. 
DINAMARCO, Cândido Rangel. Instituições de direito processual civil. 6. ed. São Paulo: Malheiros Ed., 2009. v. 2 e 3.

. Instituições de direito processual civil. 2. ed. São Paulo: Malheiros Ed., 2002. v. 1.

. A instrumentalidade do processo. São Paulo: Malheiros Ed., 2008.

. A instrumentalidade do processo. São Paulo: Malheiros Ed., 2004.

Relativizar a coisa julgada material. Revista Forense, Rio de Janeiro, v. 358, p.

11-32, nov./dez. 2001.

FAZZALARI, Elio; LUISO, Francesco P. Codice di procedura civile e norme complementari, Milano: Giuffrè, 1999.

FERREIRA, Aurélio Buarque de Holanda. Novo Dicionário da Língua Portuguesa. 1. ed. 15. Reimpr. Rio de Janeiro: Ed. Nova Fronteira.

FRANCESCHINELLI, Edmilson Villaron. Erro de fato na ação rescisória. Pressupostos necessários. Conceito. Causas determinantes. RJTE, v. 109, p. 29-41.

GEBRIN, Vera Lúcia. O erro no novo código civil. São Paulo: Forense, 2005.

GONÇALVES, Daniella Zagari. A violação de literal disposição de lei como fundamento da ação rescisória no direito brasileiro. 2000. Dissertação (Mestrado) - Faculdade de Direito, Universidade de São Paulo. São Paulo, 2000.

GRINOVER, Ada Pellegrini. Ação rescisória e divergência de interpretação em matéria constitucional. In: A marcha do processo. São Paulo: Forense Universitária, 2000. Ação rescisória. Erro de fato. Atualização de dívida de dinheiro como sendo de valor (parecer). Revista da Faculdade de Direito da Universidade Federal de Pelotas, ano 19, n. 14, p. 201-209, 1985.

Ação rescisória: desconstituição de decisão condenatória ao pagamento de verba honorária (parecer). Revista Jurídica, ano 56, n. 363, p. 55-86, jan. 2008.

. Invalidade dos atos processuais e ação rescisória. Revista IOB, Porto Alegre, v. 7, n. 39, p. 63-79, jan./fev. 2006.

et al. Código brasileiro de defesa do consumidor comentado pelos autores do anteprojeto. Rio de Janeiro: Forense Universitária, 2007. 
LEITE, Clarisse Frechiani Lara. O conceito de sentença. In: COSTA, Susana Henriques da (Coord.). A nova execução civil: Lei 11.232/05, São Paulo: Quartier Latin, 2006.

LIEBMAN, Enrico Tullio. Citação inicial. Falta - nulidade absoluta da sentença, embora já transitada em julgado - Parecer. Revista dos Tribunais, São Paulo, ano 33, v. 152, p. $443-$ 446, nov. 1944.

. Eficácia e autoridade da sentença e outros escritos sobre a coisa julgada. Trad. Alfredo Buzaid e Benvindo Aires. Rio de Janeiro: Forense, 1945.

Embargos do executado. Oposição de mérito no processo de execução. Tradução da 2. edição italiana por J. Guimarães Menegale. São Paulo: Saraiva, 1952.

Manual de direito processual civil. Tradução e notas de Cândido R. Dinamarco.

Rio de Janeiro: Forense, 1984. v. 1.

. Problemi del processo civile. Napoli: Morano, 1962.

. Processo de execução. São Paulo: Saraiva, 1980.

LIMA, Alcides de Mendonça. Introdução aos recursos cíveis. São Paulo: Ed. Revista dos Tribunais, 1976.

MAGRI, Berenice Soubhie Nogueira. Ação anulatória: art. 486 do CPC. São Paulo: Ed. Revista dos Tribunais, 2004.

MAIA, Izabelle Albuquerque Costa. Violação à súmula vinculante e cabimento de ação rescisória. In: FUX, Luiz et al. (Coord.). Processo e Constituição: estudos em homenagem ao professor José Carlos Barbosa Moreira. São Paulo: Ed. Revista dos Tribunais, 2006.

MANCUSO, Rodolfo de Camargo. Recurso extraordinário e recurso especial. São Paulo: Ed. Revista dos Tribunais, 1996.

MANDRIOLI, Crisanto. Corso di diritto processuale civile: il processo di cognizione. Torino: G. Giappichelli, 2000. v. 2.

MARCATO, Antonio Carlos. O processo monitório brasileiro. São Paulo: Malheiros Ed., 1998.

(Coord.). Código de processo civil interpretado. São Paulo: Atlas, 2005.

MARINONI, Luiz Guilherme. Coisa julgada inconstitucional. São Paulo: Ed. Revista dos Tribunais, 2008. 
MARINONI, Luiz Guilherme. Tutela antecipatória e julgamento antecipado: parte incontroversa da demanda. São Paulo: Ed. Revista dos Tribunais, 2002.

MARQUES, José Frederico. Instituições de direito processual civil. rev. atual. e comp. por Ovídio Rocha Barros Sandoval. Campinas: Millennium, 2000.

MOREIRA, Carlos Roberto Barbosa. Pronunciamento judicial sobre o fato e julgamento colegiado: interpretação do art. 485, $\S 2^{\circ}$, do CPC. Revista de Processo. São Paulo, ano 26, n. 104, p. 150-163, out./dez. 2001.

NEGRÃO, Theotonio; GOUVÊA, José Roberto F. Código de processo civil e legislação processual em vigor. São Paulo: Saraiva, 2009.

NERY JUNIOR, Nelson; NERY, Rosa Maria de Andrade. Código de processo civil comentado e legislação processual civil extravagante em vigor: atualizado até 15.03.2002. São Paulo: Ed. Revista dos Tribunais, 2002.

NEVES, Celso. Coisa julgada civil. São Paulo: Ed. Revista dos Tribunais, 1971.

NORONHA, Carlos Silveira. Sentença civil: perfil histórico-dogmatico. São Paulo: Ed. Revista dos Tribunais, 1995.

PARENTE, Eduardo de Albuquerque. Institutos equivalentes à ação rescisória. Revista de Processo, São Paulo, ano 28, n. 112, p. 124-150, out./dez. 2003.

PEREIRA, Caio Mário da Silva. Instituições de direito civil. rev. e atual. por Maria Celina Bodin de Moraes. Rio de Janeiro: Forense, 2006. v. 1.

PEREIRA, Rosalina Pinto da Costa Rodrigues. O art. 485, V, do Código de Processo Civil. Revista de Processo, São Paulo, ano 22, n. 86, p. 112-147, abr./jun. 1997.

PINTO, Nelson Luiz. Manual dos recursos cíveis. São Paulo: Malheiros Ed., 1999.

PISANI, Andrea Proto. Lezioni di diritto processuale civile. Napoli: E. Jovene, 1999.

PONTES DE MIRANDA, Francisco Cavalcanti. Acção rescisoria contra as sentenças. Rio de Janeiro: Livraria Jacinto, 1934.

Tratado da ação rescisória das sentenças e de outras decisões. Rio de Janeiro: Forense, 1976.

RÁO, Vicente. Ato jurídico. Noção, pressupostos, elementos essenciais e acidentais. $O$ problema do conflito entre os elementos volitivos e a declaração. 4. ed. anotada, revisada e atualizada por Ovídio Rocha Barros Sandoval. São Paulo: Ed. Revista dos Tribunais, 1999. 
RIZZI, Sérgio. Ação rescisória. São Paulo: Ed. Revista dos Tribunais, 1979.

RODRIGUES, Silvio. Dos vícios do consentimento. São Paulo: Saraiva, 1979.

SANCHES, Sydney. Ação rescisória por erro de fato. Revista de Processo. São Paulo, ano 11, n. 44, p. 44-68, out./dez. 1986.

SATTA, Salvatore. Diritto processuale civile. Padova: Cedam, 1950.

SAVIGNY, Friedrich Kark Von. Storia del diritto romano nel medio evo, Firenze: Vincenzo Batelli, 1844.

SIDOU, J. M. Othon. Dicionário jurídico. Academia Brasileira de Letras Jurídicas. Rio de Janeiro: Forense Universitária, 1997.

SILVA, De Plácido e. Vocabulário jurídico. Atualizadores: Nagib Slaibi Filho e Glaucia Carvalho. Rio de Janeiro: Ed. Forense, 2004.

TALAMINI, Eduardo. Coisa julgada e sua revisão. São Paulo: Ed. Revista dos Tribunais, 2005 .

THEODORO JÚNIOR, Humberto. Curso de direito processual civil. Rio de Janeiro: Forense, 2000. v. 1.

; FARIA, Juliana Cordeiro de. Reflexões sobre o princípio da intangibilidade da coisa julgada e sua relativização, in NASCIMENTO, Carlos Valder do; DELGADO, José Augusto (Org.). Coisa julgada inconstitucional, Belo Horizonte: Fórum, 2008, p. 161-199. TUCCI, Rogério Lauria; CRUZ E TUCCI, José Rogério. Constituição de 1988 e processo: regramentos e garantias constitucionais do processo. São Paulo: Saraiva, 1989.

VENOSA, Sílvio de Salvo. Direito civil: parte geral. São Paulo: Atlas, 2007. v. 1.

VIDIGAL, Luis Eulálio de Bueno. Ação rescisória dos julgados. São Paulo: Saraiva, 1948. WAMBIER, Teresa Arruda Alvim. Nulidades de processo e da sentença. São Paulo: Ed. Revista dos Tribunais, 1997.

Recurso especial, recurso extraordinário e ação rescisória. São Paulo: Editora RT, 2008.

Sobre a súmula 343. Revista dos Tribunais, São Paulo, ano 22, n. 86, p. 148-157, abr./jun. 1997. 
WAMBIER, Teresa Arruda Alvim; MEDINA, José Miguel Garcia. O dogma da coisa julgada: hipóteses de relativização. São Paulo: Ed. Revista dos Tribunais, 2003.

YARSHELL, Flávio Luiz. Ação rescisória: juízos rescindente e rescisório. São Paulo: Malheiros Ed., 2005.

Ação rescisória voltada contra decisão que reconhece a inadmissibilidade do recurso. In: DIDIER JR., Fredie (Coord.). Execução civil: estudos em homenagem ao professor Paulo Furtado. Rio de Janeiro: Lúmen Júris, 2006. Tutela jurisdicional. São Paulo: Atlas, 1998.

ZAVASCKI, Teori Albino. Ação rescisória: a súmula n. 343-STF e as funções institucionais do Superior Tribunal de Justiça. In: SUPERIOR Tribunal de Justiça: doutrina: edição comemorativa, 20 anos. Brasília/DF: STJ, 2009.

Defesas do executado. In: RENAULT, Sergio et al. (Coord.). A nova execução de títulos judiciais: comentários à lei 11.232/05. São Paulo: Saraiva, 2006. 